\title{
Audit of Petroleum Exploration Wells in the UK Rockall Basin: 1980-2006
}

by

Nick Schofield - University of Aberdeen (n.schofield@abdn.ac.uk)

Lena Broadley - University of Aberdeen (lena.broadley@abdn.ac.uk)

David Jolley - University of Aberdeen (d.jolley@abdn.ac.uk)

Non-Peer Reviewed Document (Final Version - 2019)

This document was produced as part of a 2 year research project to re-examine the propsectivity of the UK Rockall funded by the Oil and Gas Authority of the United Kingdom

The document is also freely available from the OGA website 


\section{Audit of Petroleum Exploration Wells in the UK Rockall Basin: 1980-2006}

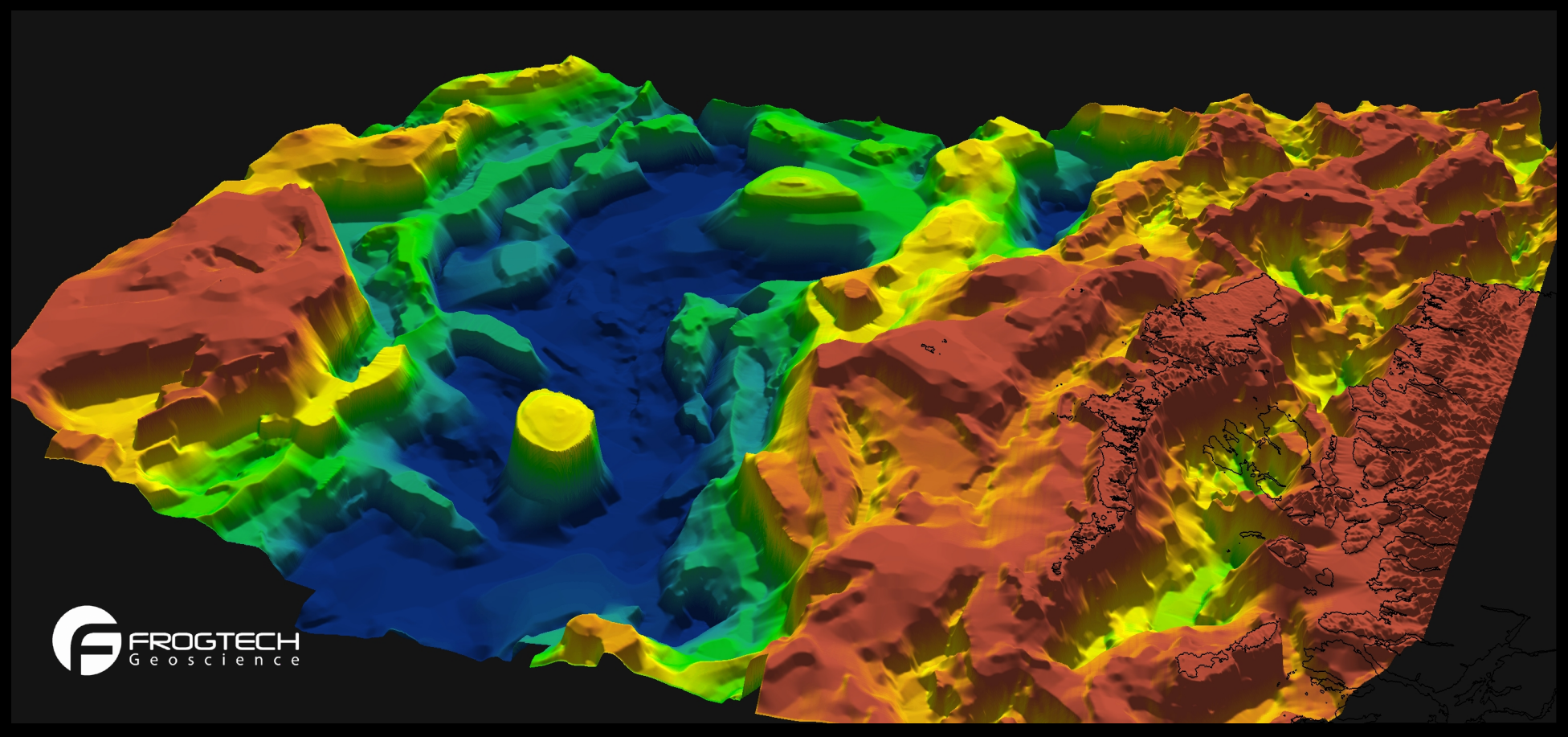

By

Nick Schofield, Lena Broadley, David Jolley

Final Version 2019 
Audit of Petroleum Exploration Wells in the UK Rockall Basin 1980-2006

Report prepared for the Oil and Gas Authority (OGA) Frontier Basins Research Program

January 2019

By

Dr. Nick Schofield (University of Aberdeen)

Dr. Lena Broadley (University of Aberdeen)

Prof. David Jolley (University of Aberdeen)

\section{Further Details:}

Dr. Nick Schofield (n.schofield@abdn.ac.uk)

Department of Geology and Petroleum Geology

University of Aberdeen

Aberdeen

AB24 3UE

Cover Image: Image derived from Frogtech Geoscience SEEBASE depth to basement grid (http://www.frogtech.com.au/) 


\section{Usage of Report}

Any element of this report is available for free use, however any element utilised within internal or external presentations and/or reports should be acknowledged with the following "University of Aberdeen OGA Rockall Project: Well Audit" or the below reference.

Bibliographic reference:

Schofield, N.J,, Broadley, L., Jolley, D.W., 2019, Audit of Petroleum Exploration Wells in the UK Rockall Basin 1980-2006. Final Version, University of Aberdeen

\section{Preface to Final Version of Well Audit}

Please note that the stratigraphic summaries of the wells presented within this report are taken directly from released well documents (e.g. Final Well Report, Composite Logs). Although the broad stratigraphic summary of the wells presented (e.g. Eocene, Paleocene, and Cretaceous) is mostly accurate, depths of individual formation tops (e.g. Lamba, Vaila) should be treated with some caution.

The biostratigraphic revaluation and formation tops of key wells is presented in the OGA UK Frontier Basins Project: Rockall Regional Study Final Report which accompanies the Petrel and ArcGIS database.

\section{University of Aberdeen Rockall Project website: http://www.rockallbasin.com/}

Disclaimer: The views and opinions expressed in the following report are those of the individual authors and do not necessarily represent the official policy or position of the UK Oil and Gas Authority. 


\section{Contents}

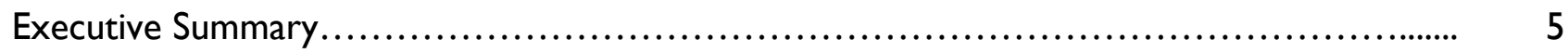

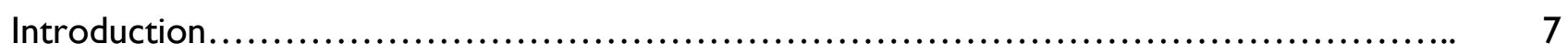

Geology of the UK Rockall...................................................... 13

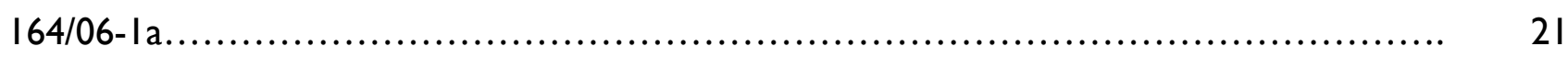

$|64 / 25-I$,$| Iz................................................................ 25$

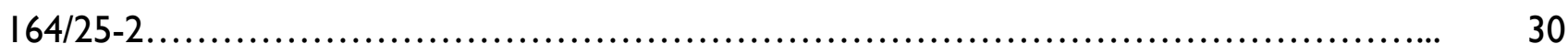

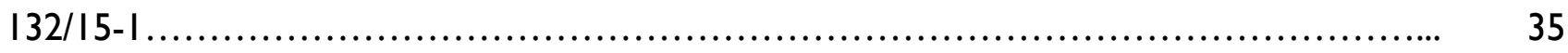

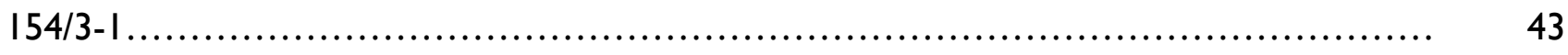

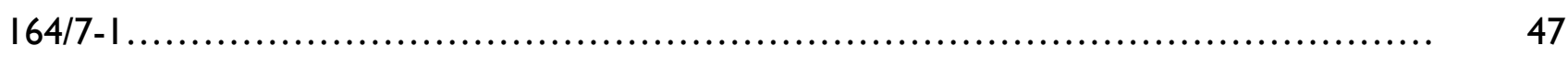

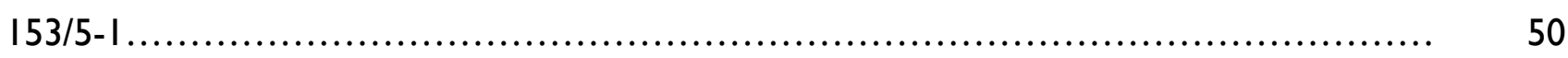

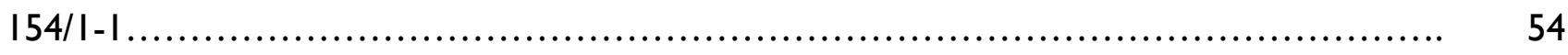

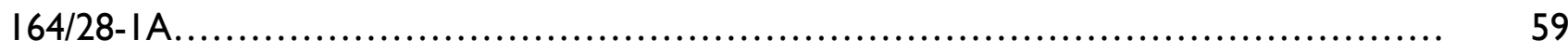

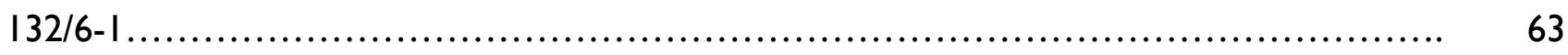

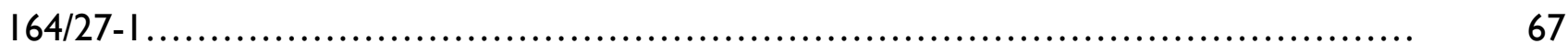

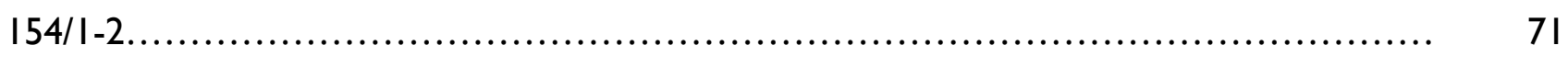

Findings of UK Rockall Well Audit.............................................. 75

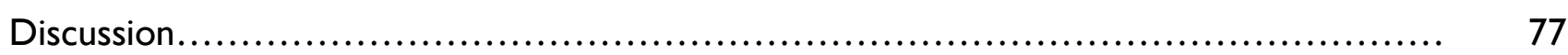

Closing Remarks and Future Recommendations.................................... 78

Acknowledgments.......................................................... 79

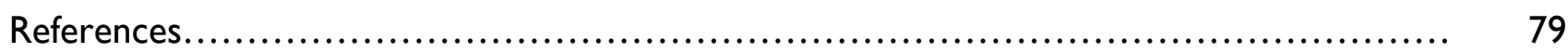




\section{Executive Summary - UK Rockall Well Audit (1980-2006)}

The UK Rockall Basin is one of the most underexplored areas of the UK Continental Shelf (UKCS) with only 12 exploration wells drilled since 1980, in a basin area that is equal in size to the entire North Sea hydrocarbon province (NNS, CNS \& SNS). With only one discovery, made in 2000 (Benbecula South I54/I-I Gas discovery), the general view of the basin from an exploration viewpoint has not been traditionally positive. The overriding aim of this document is to allow an accessible introduction to the exploration history and hydrocarbon prospectivity of the Rockall region, while at the same time highlighting some of the recent advances in understanding of the basin. Importantly, this report highlights that although the ratio of I discovery to II dry wells can be interpreted as indicating a basin with little to no viable petroleum system, this statistic is misleading. As of 2019, based on the assessment in this report, we would argue that the discovery to dry hole ratio is closer to I:6 (rather than I:I I), due to five wells being drilled on invalid geological targets, as a result of lacking subsurface knowledge and/or poor quality seismic data. In addition to this, there is a lack of deep well penetrations with the UK Rockall, with only one well reaching sedimentary strata older then the Cretaceous, meaning that the detailed stratigraphy of the area is still largely unknown.

The exploration narrative of the UK Rockall should be placed in context in regard to the rest of the UKCS, where from the years 1965-2007, a total of 2268' exploration wells were drilled (compared against the 12 drilled in the UK Rockall from 1980-2006). Therefore, it must be argued that, as of 2019, not enough subsurface geological information currently exists within the UK Rockall to assess the viability of the petroleum system. 


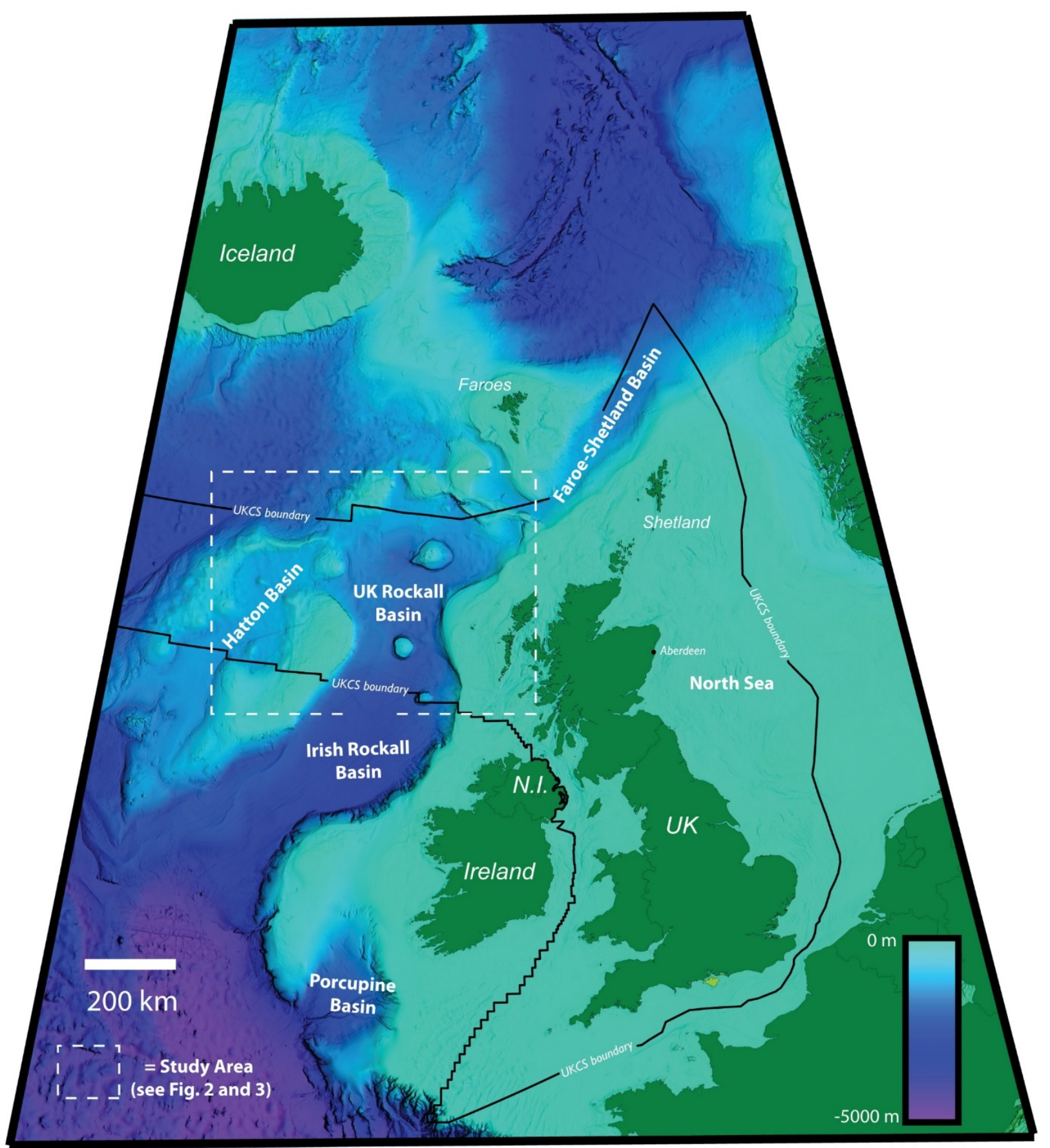

Figure I - Bathymetry map of the UK Continental Shelf (UKCS) and area of the UK Rockall Basin that this report covers (From Schofield et al. 2018) 


\section{Introduction}

The following wells are included in this report. The data for each well was collated from released well documents and published material and on this basis, it is important to acknowledge the extensive analysis conducted on these wells by a range of operators and contractors. Where applicable, additional information relevant to wells has been added, based on knowledge acquired along the margin since some wells have been drilled (e.g. Colsay Fm. sequences within 164/25- 2, which were not known at time of drilling the well). The wells are presented in a chronologically, to enable to reader to see how exploration narrative and industry thinking developed in the basin from 1980 to 2006, with the increasing quality of seismic data and subsurface knowledge.

\begin{tabular}{|c|c|c|c|}
\hline $\begin{array}{c}\text { Well } \\
\text { I63/6- IA }\end{array}$ & $\begin{array}{c}\text { Year Drilled } \\
1980\end{array}$ & $\begin{array}{l}\text { Operator } \\
\text { BNOC }\end{array}$ & $\begin{array}{c}\text { Completion Status } \\
\text { Dry }\end{array}$ \\
\hline $164 / 25-1 z$ & 1988 & $\mathrm{BP}$ & Dry \\
\hline $164 / 25-2$ & 1990 & $\mathrm{BP}$ & Dry \\
\hline $132 / 15-1$ & |99| & $\mathrm{BP}$ & Dry \\
\hline I54/3- I & I99I & Conoco & Dry \\
\hline I64/7- I & 1997 & Conoco & Dry \\
\hline $153 / 5-1$ & 2000 & $\overline{\text { Marathon }}$ & Dry \\
\hline $154 / 1-1$ & 2000 & $\overline{\text { Enterprise }}$ & Gas Discovery \\
\hline I64/28- Ia & 2000 & $\overline{\text { ENI/AGIP }}$ & Oil Shows \\
\hline $132 / 6-1$ & 2001 & Conoco & Dry \\
\hline I64/27- I & 2002 & $\mathrm{ENI}$ & Dry \\
\hline $154 / 1-2$ & 2006 & Shell & Dry \\
\hline
\end{tabular}

Exploration within the UK Rockall falls into two main phases (Fig. 2). The first phase from I988 until 1992 was characterised by highly frontier rank wildcat exploration, often targeting pre-rift plays, which led to five wells being drilled (four by BNOC/BP and one by Conoco) with no discoveries, but allowing for some subsurface geological control and knowledge to be established. The second phase, from 1997 until 2003, saw the basin being entered by other operators such as ENI, Enterprise and Shell, with exploration more targeted and aimed at four-way dip closures along the eastern margin of the basin. Between 2000 and 2003, the UK Rockall underwent an 'intensive' exploration period, with five out of the total 12 wells drilled in the area during this time. The last exploration well drilled (as of 2018) in the UK Rockall was in 2006 by Shell, bringing to a close 26 years of disappointing exploration results. 


\section{Pre-Rift Plays}

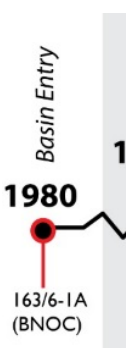

\section{Phase I}

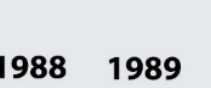

132/15-1 (BP) 4-way closures

\section{Phase 2}

153/5-I (Marathon)

154/1-I (Benbecula South - Enterprise)

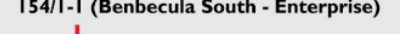

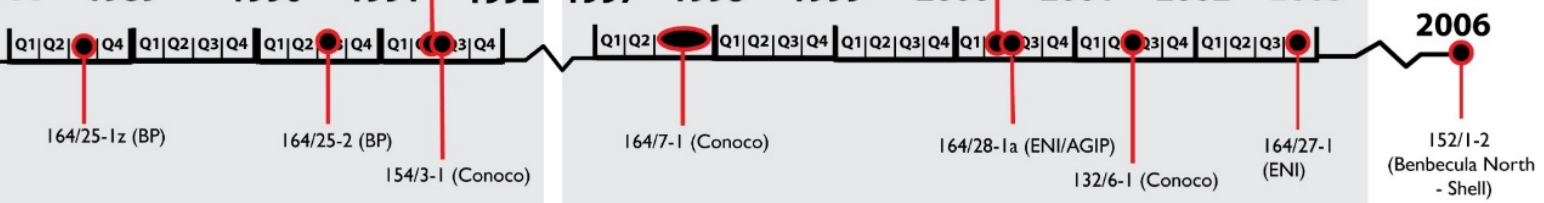

Figure 2 - Timeline of exploration within the UK Rockall Basin. Phase I was characterised by wildcat wells, targeted on limited understanding of the subsurface geology. Phase 2 was characterised by more focused play driven exploration, targeting specific targets and/or stratigraphic units (e.g. Vaila Fm.). From Schofield et al. (2018) 

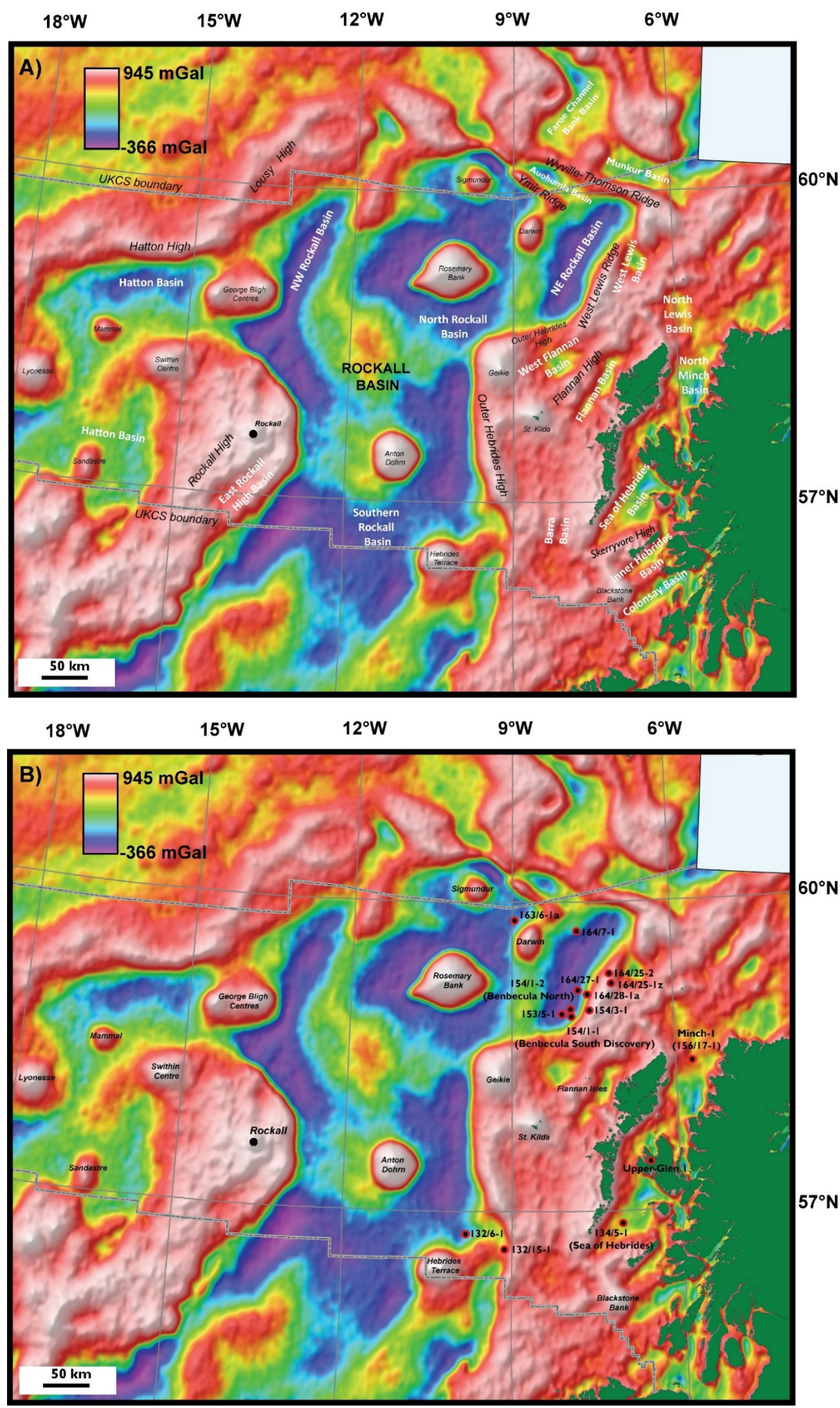

Figure 3 - From Schofield et al. (2018) showing main structural elements of the Rockall Basin and wells drilled. Note the focus of exploration has been within eastern margin, and in particular NE Rockall Basin 


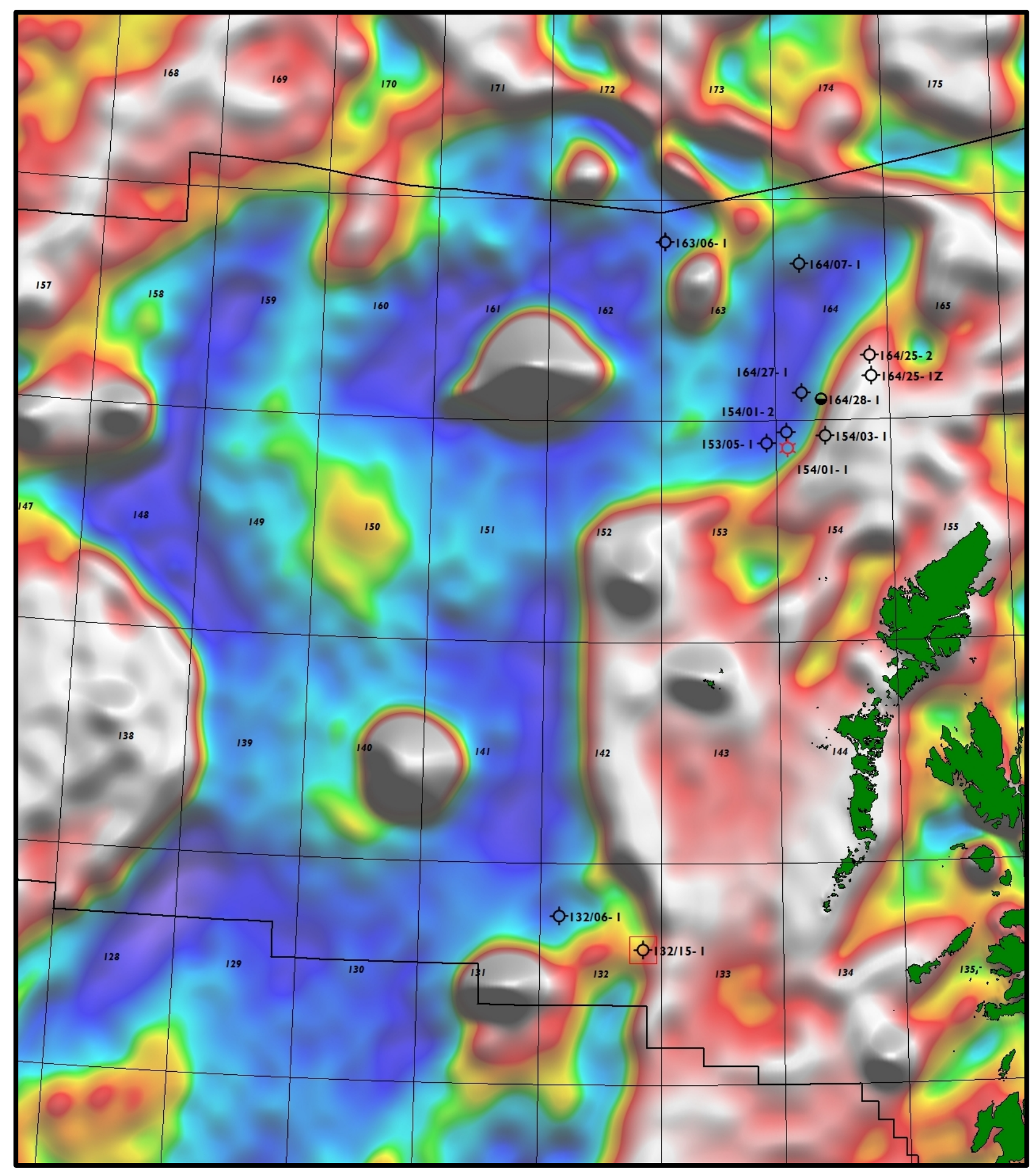

Figure 4 - Free-air anomaly map showing all wells drilled within the UK Rockall Basin (WGM 2012 gravity data courtesy of International Gravimetric Bureau) 


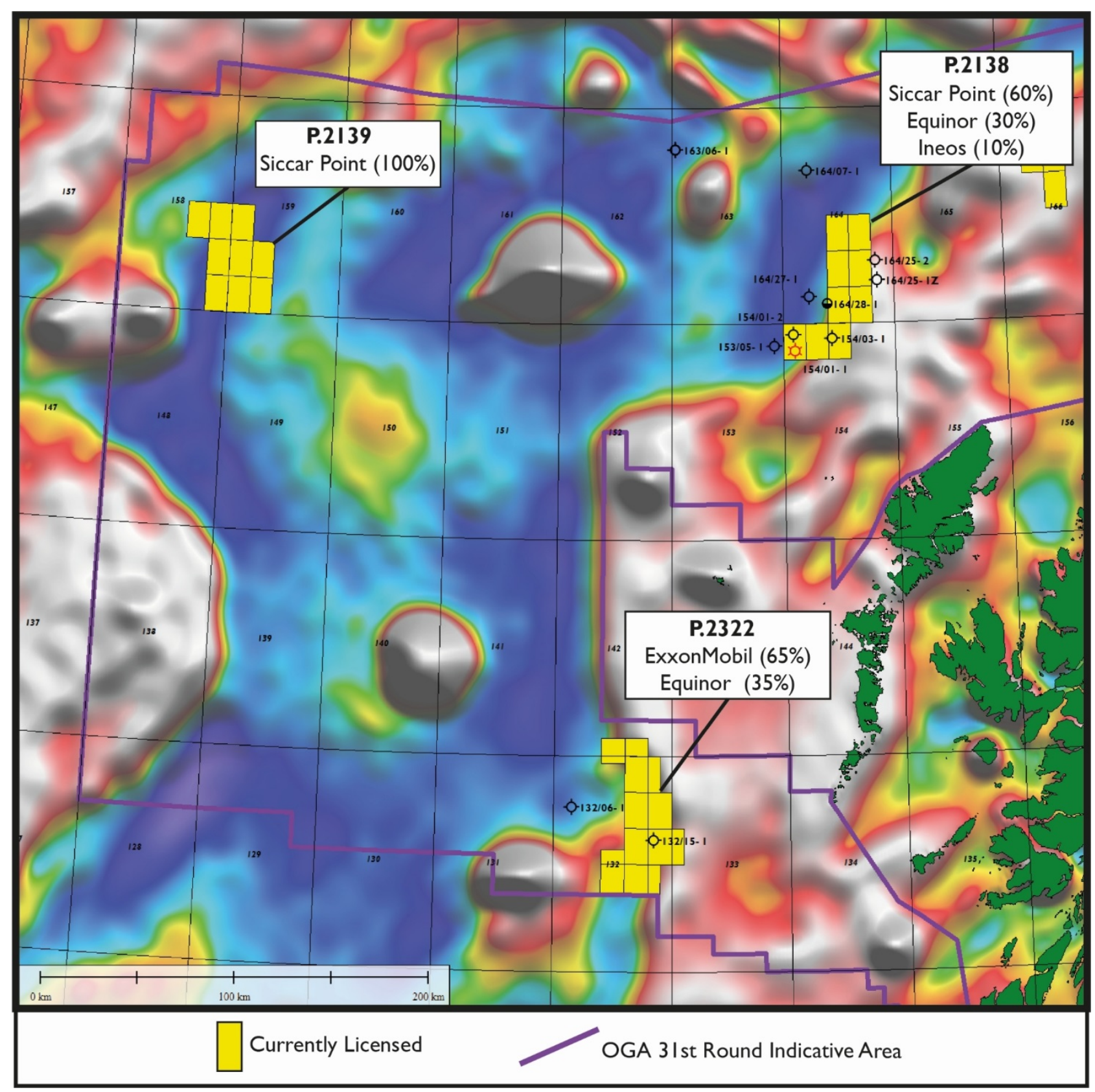

Figure 5 - Current licenses held within the UK Rockall going into $31^{\text {st }}$ Round (20I8) 


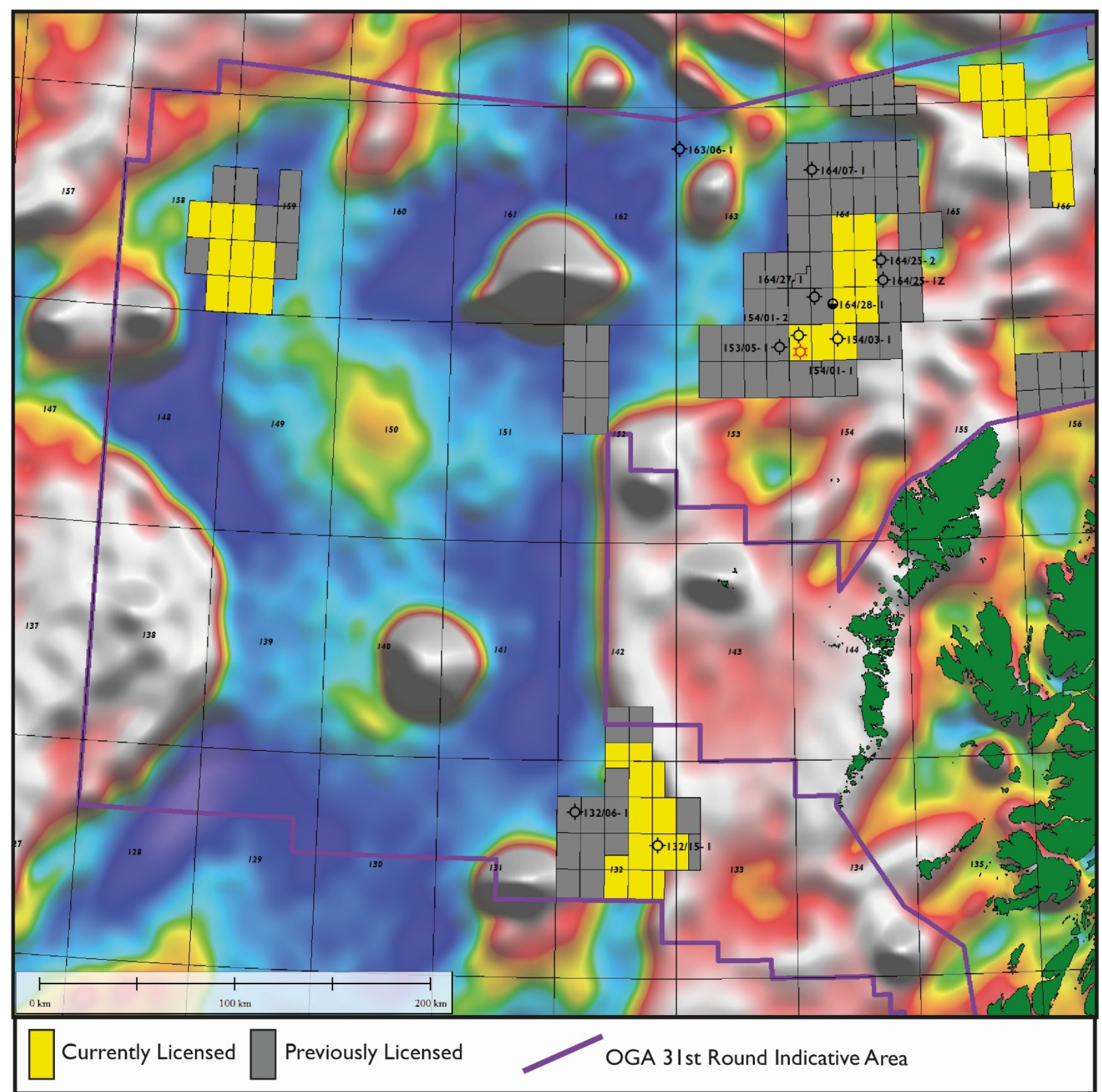

Figure 6 - Current and Previous licenses held within the UK Rockall going into $3 I^{\text {st }}$ Round (20I8) 


\section{Geology of the UK Rockall}

\section{Structural Framework}

The detailed geological evolution of the Rockall Basin is still largely unknown, due to the lack of deep well penetrations in the basin, and limited coverage of good quality seismic data, however its development is thought to be comparable with that of the adjacent Faroe-Shetland Basin.

The Precambrian basement likely compromises of two major basement terranes, sutured across the Anton Dohrn Lineament (Doré et al. 1997; Hitchen et al. 2013). The presence of Middle Proterozoic through to Devonian sequences are currently largely unknown in the Rockall area, however the existence of such sequences within the Faroe-Shetland Basin (e.g. Rona Ridge) suggest that they are probably present within Rockall. During the Silurian to Early Devonian, the Caledonian Orogeny led to compression of the area, resulting in the North East-South West structural grain that has subsequently influenced much of the rift orientation along the Atlantic Margin (Fig. I, 2 and 3) (Hitchen et al. 20I3)

Although now bathymetrically separated by the Wyville-Thomson Ridge (Fig. 3), the NE Rockall Basin is assumed to have undergone a similar rift history to that of the Faroe-Shetland Basin to the north (Archer et al. 2005). Since the collapse of the Caledonides during the late Silurian-early Devonian a complex multi-phase rift history has evolved. A Triassic to Early Cretaceous rift phase and Late Cretaceous to Paleogene post-rift phase appear to characterise much of the stratigraphy of the Rockall Basin (Musgrove and Mitchener, 1996; Archer et al. 2005). The Rockall, may have become hyperextended during Early Cretaceous rifting, leading to the potential for high segmentation and lack of coherent Jurassic and older sequences towards the centre of the basin (Lundin and Doré, 20I I).

\section{Source Rocks}

Although Jurassic source rocks are proven within the Faroe-Shetland Basin, their presence or absence within the deep-water Rockall Basin, away from the Outer Hebrides High, has not been definitively established. The first clearly discernible phases of rifting within Rockall during the Mesozoic are difficult to constrain, with only one well penetration of pre-Cretaceous strata (Permian-Triassic - I64/25-IZ) (Fig $3,4 \& 5)$. However, it is likely that as with much of West of Britain at this time, rifting was potentially first manifested during the Permo-Triassic, with development of narrow, shallow, mostly continental rift-basins (Morton, 1992; Doré et al. 1997; Stolfova and Shannon, 2009). Progressing into the Jurassic, within the Inner Hebrides, significant rifting took place in a series of half-grabens with deposition of thick Early Jurassic and Middle Jurassic sequences (Stein and Blundell 1990; England et al. 1993), and potentially Upper Jurassic, although later uplift and erosion makes discerning this difficult (Holford et al. 20I0).

Within the UK Rockall, the extent of both intra-continental Triassic and then more extensive Jurassic rifting, or nature of the rift geometry, beyond plate reconstructions (Cole and Peachey, 1999; Nadin et al. 1999) is not entirely clear. Assessing the areal extent of Jurassic rocks in deeper areas of the basin is still difficult due to the overlying Palaeogene extrusive lava and intrusive sill complex. Within the Inner Hebrides (Fig. 3), the Triassic-Jurassic succession records an initial deepening from late Triassic fluvial deposits into organic-rich Lower Jurassic marine mudstones (Fig. 7). This is followed by shallowing through tide and wave dominated shallow marine clastics (Bajocian), into organic-rich lagoonal and fluvial deposits in the Bathonian (Bathonian - Great Estuarine Group) prior to the global Callovian transgression and a return to Upper Jurassic (Kimmeridgian) marine mudstone deposition (Trewin, 1992). These marginal to non-marine conditions during the early to mid-Jurassic appear, in part, appear to have extended across the Outer Hebrides landmass towards Rockall. Shallow borehole 90/2 on the Outer Hebrides Shelf is interpreted to have intersected Bathonian shales (equivalent to the Middle Jurassic Great Estuarine Group in the Inner Hebrides), with high TOC (3.4-8\%), deposited in a lacustrine/lagoonal environment (Hitchen et al. 2013). Kimmeridge Clay Fm. equivalent mudstones have been penetrated in 
shallow boreholes in both the West Flannan Basin (90/09) and West Lewis Basin (90/05). However, unlike the North Sea, which possesses widespread development of oil-prone late Jurassic marine source rock (e.g. the Kimmeridge), oil-source correlation studies along the Atlantic Margin indicate several source intervals ranging in age from Early to Late Jurassic, in facies varying from lacustrine, fluvio-deltaic to marginal marine (Scotchman et al. 2016). This aspect points to a discrete series of rift sub-basins, with varying geological histories and sub-surface lithologies.

Other potential source rock units, e.g. of Carboniferous age, are not proven within the UK Rockall. However, within the Irish sector, Carboniferous source rocks have been proven on the eastern flank of the basin (Shannon and Naylor, 2010). The northern extent of these Carboniferous rocks is not clear; onshore, the northernmost extent of Carboniferous rocks along the West Coast of Scotland is seen at Inninmore bay, Morvern, adjacent to the Isle of Mull, comprising of a Westphalian age coal-bearing sequence (Fyfe et al. 1993). However, no other known outcrops are present north of this. Wells drilled onshore and offshore Skye (e.g. I34/5-I, Upper-Glen I) (Fig. 3) only penetrated as far as the Triassic, but Minch-I drilled in the North Minch Basin, $30 \mathrm{~km}$ east of north Lewis (Fig. 3), found a Permian-Triassic sequence unconformably overlying the Precambrian, with no trace of the Carboniferous. Therefore although a Carboniferous source in the UK Rockall may be present in the south, it seems unlikely to be present in the north of the basin.

\section{Reservoir}

Potential reservoirs have been penetrated at multiple stratigraphic levels within the 12 UK Rockall wells. With only one exploration well penetrating pre-Cretaceous strata $(164 / 25-I, I Z)$, the main proven reservoir intervals within the UK Rockall are currently found in the Cenozoic. However, samples from shallow boreholes on the Hebridean Shelf yield some insight into the potential for older reservoir sequences to exist within the area.

Eocene and Oligocene basin floor fans can be clearly identified on seismic data from the Rockall Basin. A Lowermost Eocene fan was penetrated by the 153/05-I well. The fan comprised of a thick package of coarse clastics overlain by a series of fining upward sequences of interbedded sandstones and shales. The log-derived porosity over the interval averaged around $26 \%$. The wellsite cuttings description, however, notes poor to fair visible porosity, except towards the base of the fan system, where locally excellent visible porosity is noted. The I53/05-I well documents note that earliest Eocene sandstones penetrated in 164/25-IZ, 164/25-2 and 154/03-I represent the shallow marine equivalent of this fan system. Reservoir quality of these sandstones was not evaluated, possibly because the interval above the volcanics may not have been considered prospective at the time of drilling, due to a lack of structural traps. Based on the log descriptions, the sequence encountered in 164/25-IZ and 164/25-2 consisted of predominantly arenitic, medium to coarse grained, moderately to well-sorted sandstones, which may have some reservoir potential. The same sequence in I54/03-I is described as being argillaceous sandstone with a muddy matrix and may have less reservoir potential.

The 164/25-2 well, located on the West Lewis Ridge, penetrated a 150 m thick intra-volcanic sandstone package identified in the well documents as being equivalent to the Lamba Formation. However, recent biostratigraphical analyses indicate that this interval corresponds to the Late Paleocene/Early Eocene Colsay Member of the T40 Flett Formation (Schofield et al. 2018), equivalent to the reservoir interval of the intra-lava Rosebank discovery in the Faroe-Shetland Basin. In the 164/25-2 well, this sequence exhibits excellent porosities of up to $34 \%$ and permeabilities commonly in excess of ID and up to $9 \mathrm{D}$.

The mid-Paleocene Vaila sandstones represent a key hydrocarbon play within the Faroe-Shetland Basin and wells within Rockall equally illustrate that Vaila Formation sandstone deposition was widespread 
throughout the eastern margin of the UK Rockall Basin. The hydrocarbon accumulation of the Benbecula (I54/0I-I) discovery resides in sandstones of the T22 - T35 Vaila Formation. In I54/0I-I, these sandstones were found to possess lower than expected porosities, averaging around $19 \%$, as a result of carbonate cementation. A number of other wells in the UK Rockall, I54/I-2, I64/27-I, and I64/28-IA all encountered thick Vaila Formation sandstones with average log-derived net porosities of 19-22\%. Within the South UK Rockall Basin, Vaila Formation sandstones were also encountered in the $132 / 15-1$ and 132/06-I. These sequences, however, comprised of volcaniclastic sandstones and/or siltstones, with poor reservoir potential (see I32/I5-I and I32/6-I below), representing a significant risk to this play within the southern UK Rockall.

In I64/25-I, IZ, a thick sequence of red sandstones and mudstones was ascribed a Permo-Triassic age, but the upper $\sim 180 \mathrm{~m}$ of this interval was reassigned to the Late Albian on the basis of subsequent stratigraphic analyses. Fossil assemblages suggest a mid-shelf depositional setting and the sandstones are noted to be of poor reservoir quality.

In I32/I5-I, the only other UK Rockall well to encounter Lower Cretaceous strata, the entire Lower Cretaceous section, including a thick Albian sequence, is mudstone dominated. Although well 132/I5-I found a mud dominated lower Cretaceous section, Late Albian (Victory Fm. equivalent) sandstones are found in other areas along the NE Atlantic Margin, including the Faroe-Shetland Basin, the Porcupine Basin and on the Hatton High (e.g. Mclnroy \& Hitchen, 2008). Therefore, Victory Fm. equivalent sandstones may form an important, but yet wholly unknown reservoir interval within the Cretaceous of the UK Rockall Basin. An indication that Cretaceous reservoirs may be present within the UK Rockall comes from the 88/0I shallow borehole on the eastern margin of the West Lewis Basin. The borehole found Barremian sandstones (Victory Fm. equivalent) overlying Middle Jurassic strata. The sandstones are coarse, shelly, composed of around 30-40\% matrix (Hitchen \& Stoker, 1993). The presence of these coarse Cretaceous clastics on the eastern basin margin of the UK Rockall implies that there existed a source of coarse clastic detritus in Barremian times. This may imply that potential exists for more mature Victory Fm. equivalent sandstones to have accumulated in deeper water areas, although with lack of any deep well penetrations, this is highly speculative.

As discussed in the source rock section above, Jurassic sediments were not encountered in any of the UK Rockall exploration wells. However, there are indications from shallow boreholes on the Outer Hebrides High that Jurassic-aged reservoirs may be present in the Rockall Basin. Most notable is the 90/08 borehole on the Eastern margin of the West Flannan Basin. This borehole encountered shallow marine sandstones of Kimmeridgian to Oxfordian age (Isaksen et al. 2000), which can be observed on the seismic to plunge towards the Rockall Basin, thickening to the West. The borehole proves that sediments of Upper Jurassic age exist to the West of the Hebrides and there is potential for deeper water equivalents of these shallow marine sandstones to exist in basinal areas.

Well 165/25-I,Iz penetrated red continental sandstones, siltstones and mudstones of assigned Permo-Triassic age. The interval was barren of in-situ microfossils and the age assignation is based on comparison to New Red Sandstone Group outcropping on the Isle of Lewis. The sandstones have low porosities at the well location, due to a combination of unfavourable (fine-grained) facies, illite-smectite cementation and compaction. The study of the Permo-Triassic in 164/25-IZ represents the only evaluation of reservoir quality for sediments of this age in the UK Rockall area. Shallow boreholes demonstrate, however, that Permo-Triassic sediments are widely distributed to the West of the Hebrides and plate reconstructions (e.g. Srivastava \& Verhoef, 1992; Knott et al. 1993) suggest that there was extensive continental rifting in the Rockall Basin during Permo-Triassic times. On this basis, it is considered probable that Permo-Triassic continental deposition was widespread in the Rockall basin area. 
Permo-Triassic sediments form viable reservoirs, as found in the Dooish (12/2-I) discovery in the Irish Rockall, the Corrib field in the Slyne Basin and in the Strathmore Field to the West of Shetland.

\section{Report Conventions}

- Within this report, for purposes of consistency and standardization, where possible, specific sequences are referred to in a current Atlantic Margin stratigraphic context. For example, "Sequence T28-25 Vaila Fm. equivalent". Note: This is done in terms of the equivalent chronostratigraphic age relationship, not in terms of lithology.

- For each well a prognosed vs actual stratigraphic summary is provided based on the pre-drill, final well reports and composite logs. Note: If a stratigraphic summary is only shown, this is because the pre-drill prognosed stratigraphy was not within documents (currently) submitted to CDA at time of writing. All depths in this report are based on MDBRT, unless otherwise stated.

- As noted in the preface, the detailed stratigraphy in released well data of the UK Rockall is often inconsistent between wells and in some cases erroneous, meaning that the stratigraphic summaries from the wells should be used as a broad, rather than a detailed stratigraphic guide.

- Volcanic lithological descriptions in well data from UKCS (and globally), often need to be treated with a certain amount of caution, as complete misidentification of lithologies present is very common. Where obvious errors exist, or alternative lithological interpretation applies, this is highlighted.

- Geological periods and series are referred to in line with the International Stratigraphic Commission names and the current Geological Society of London recommendation, e.g. Paleocene rather than Palaeocene. 


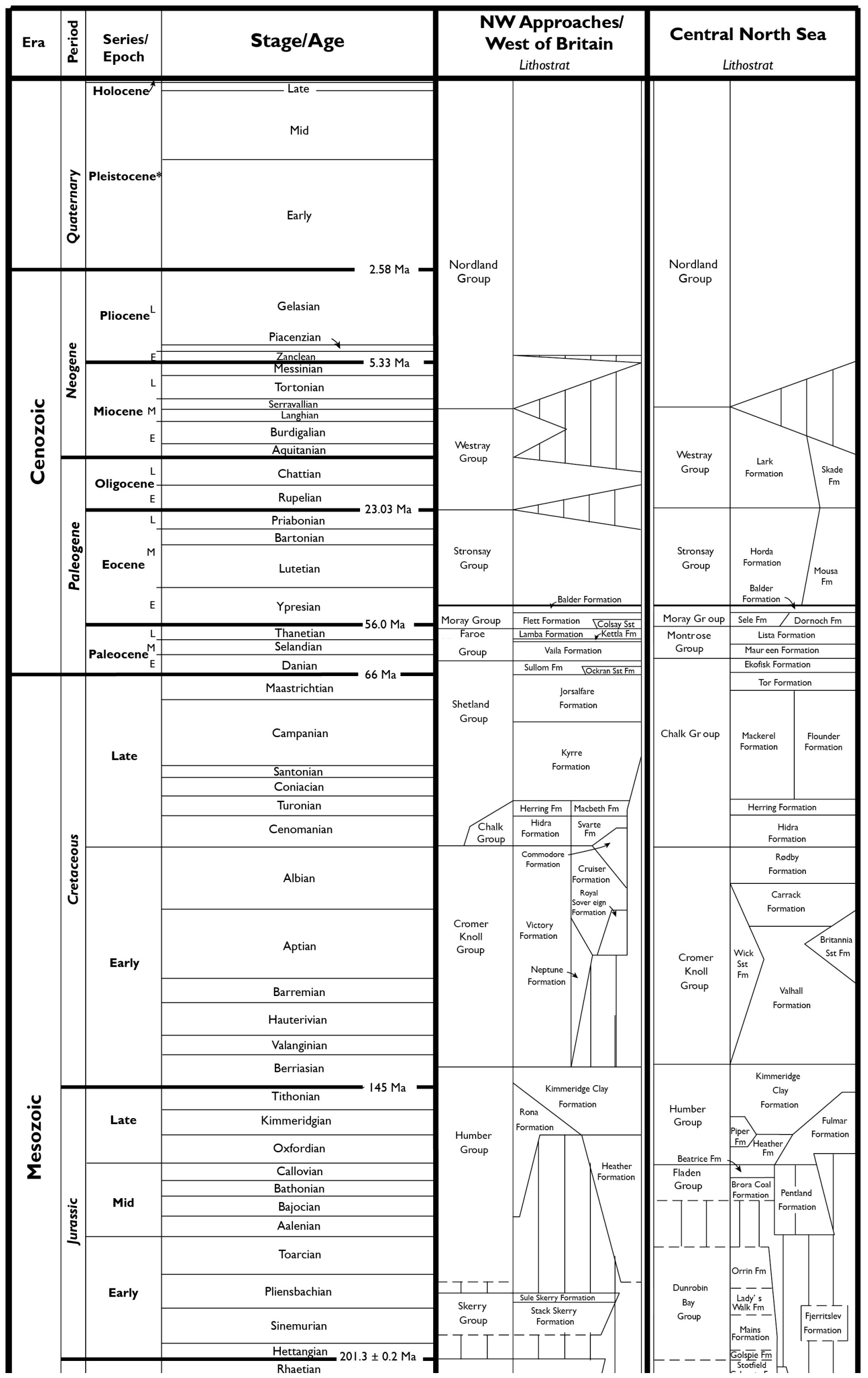




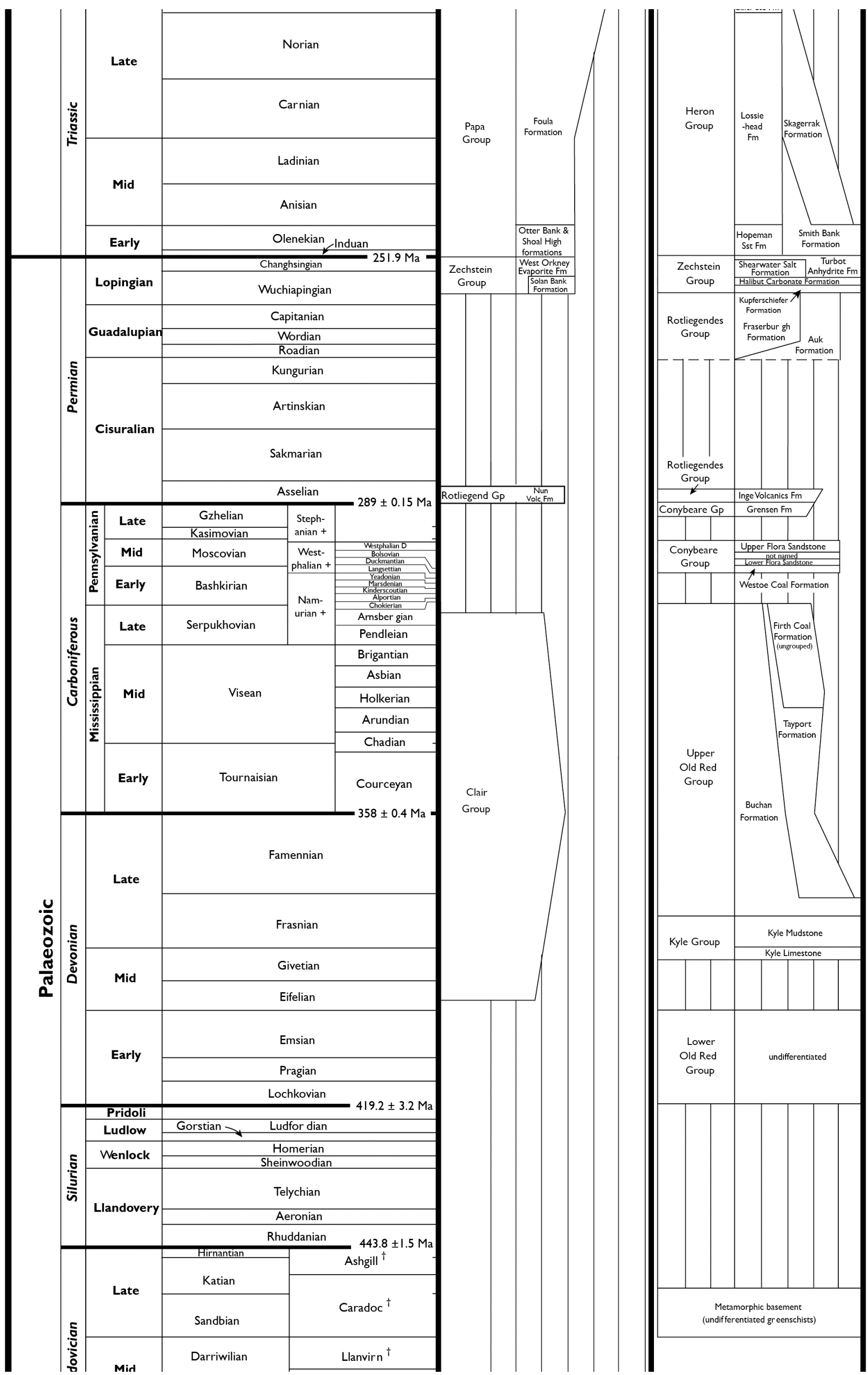




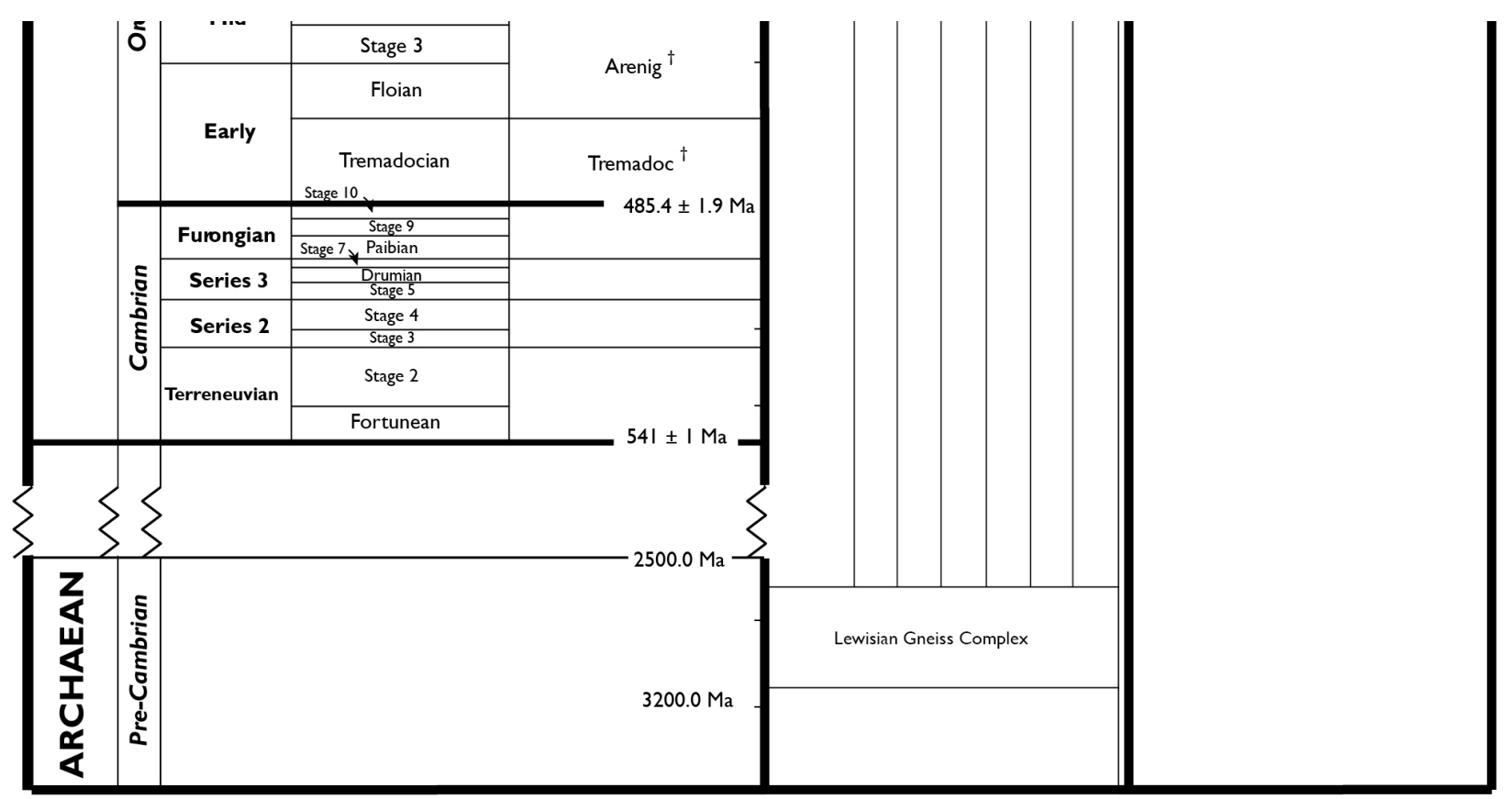

Figure 7 - Chronostratigraphic chart for West of Britain/NW approaches against comparison with Central North Sea. Modified from Waters et al. (2007). 


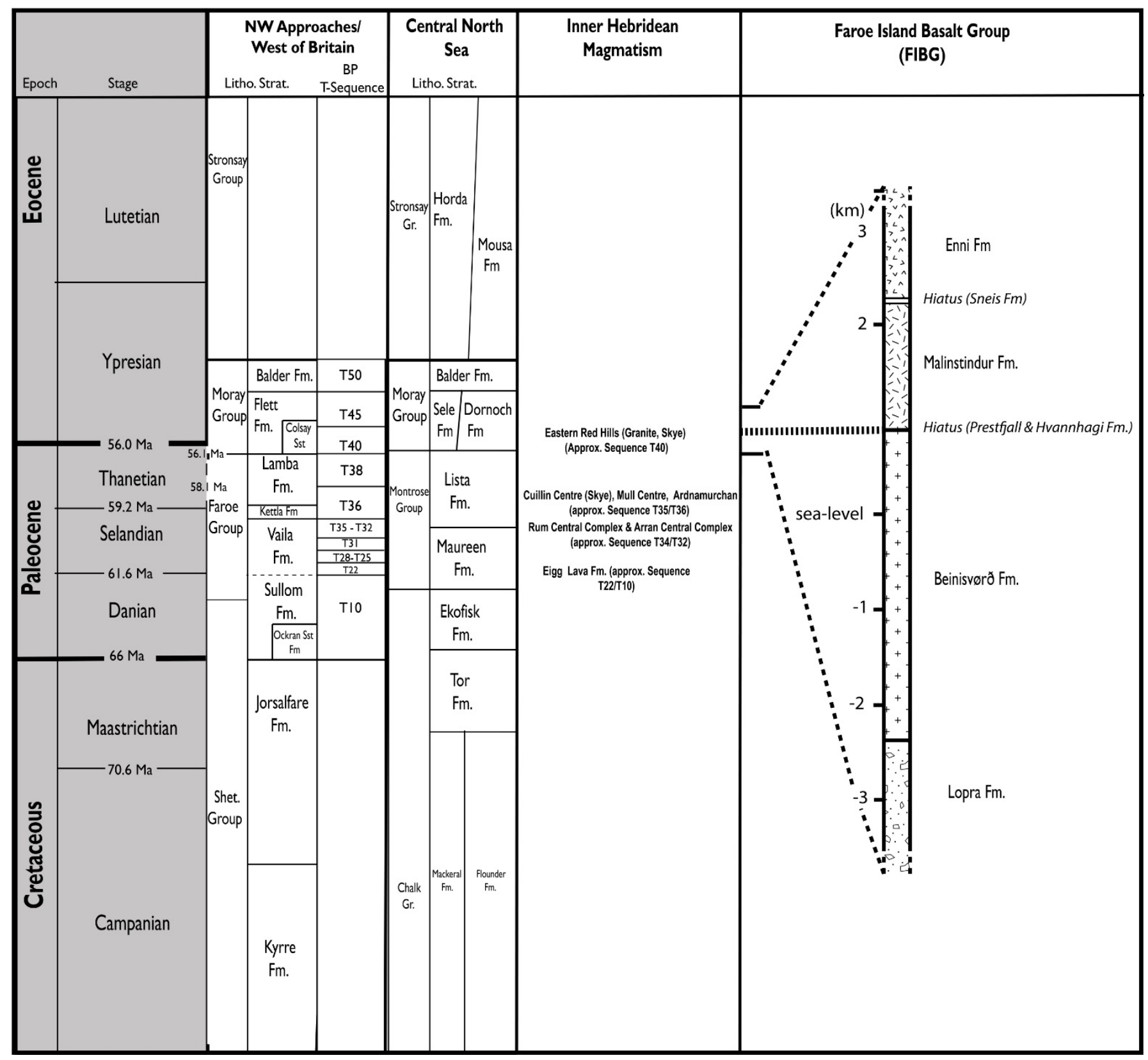

Figure 8 - Chronostratigraphic chart for Upper Cretaceous, Paleocene and Early Eocene, showing comparison of West of Britain and Central North Sea lithostratigraphy, including BP Paleocene T-sequence framework (Ebdon et al. 1995). Included is the timing and chronostratigraphy of major volcanic events along the Inner Hebrides and Atlantic Margin volcanism. (after Emeleus and Bell 2005, Waters et al. 2007; Passey and Jolley, 2009, Schofield et al. 20I8) 


\section{63/06- I A (Drilled I 980)}

\begin{tabular}{|c|c|}
\hline Operator & BNOC/Britoil \\
\hline Date Spudded & $9 / 05 / 1980$ \\
\hline TD Date & $11 / 10 / 1980$ \\
\hline Days Drilling & I56 days ( 5 months, 3 days) \\
\hline Type & Stratigraphic Test/Exploration Rank Wildcat \\
\hline Status & P\&A - Dry \\
\hline Shows & None \\
\hline License & E. 163 \\
\hline Latitude & $\begin{array}{l}59^{\circ} 48^{\prime} 39.846 " \mathrm{~N} \text { (from Survey Engineering } \\
\text { Completion report) }\end{array}$ \\
\hline Longitude & $\begin{array}{l}08^{\circ} 57^{\prime} 58.738^{\prime \prime} \mathrm{W} \text { (from Survey Engineering } \\
\text { Completion report) }\end{array}$ \\
\hline Reference Datum & ED50 \\
\hline Projection & International Spheroid \\
\hline $\mathrm{KB}(\mathrm{m})$ & 14.6 \\
\hline Water Depth $(\mathrm{m})$ & 1374 \\
\hline TD (mRT) & 3686.3 \\
\hline Age at TD & Late Paleocene Volcanics \\
\hline Primary Objective & $\begin{array}{l}\text { Stratigraphic Test/Prognosed Mesozoic } \\
\text { sedimentary foreset succession }\end{array}$ \\
\hline Secondary Objective & $\mathrm{N} / \mathrm{A}$ \\
\hline Play/Trap Style & $\begin{array}{l}\text { Prognosed deltaic sandstone sequences. No } \\
\text { defined trap }\end{array}$ \\
\hline Objectives Fulfilled & $\begin{array}{l}\text { Broad stratigraphy to Late Paleocene } \\
\text { established, however well failed to penetrate } \\
\text { volcanic sequence. }\end{array}$ \\
\hline Reason for Failure & $\begin{array}{l}\text { Invalid geological target and drilling issues - } \\
\text { The prognosed deltaic sandstone sequence } \\
\text { was likely to have been a Hyaloclastite delta }\end{array}$ \\
\hline
\end{tabular}

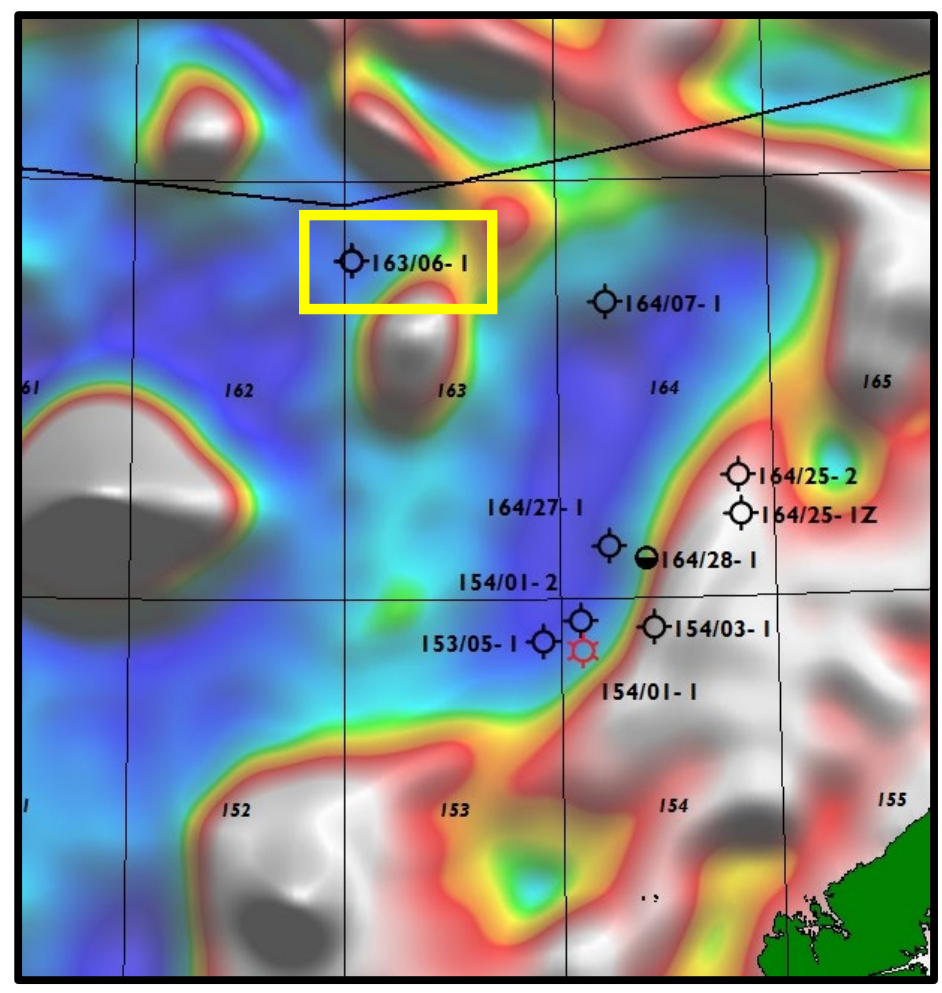




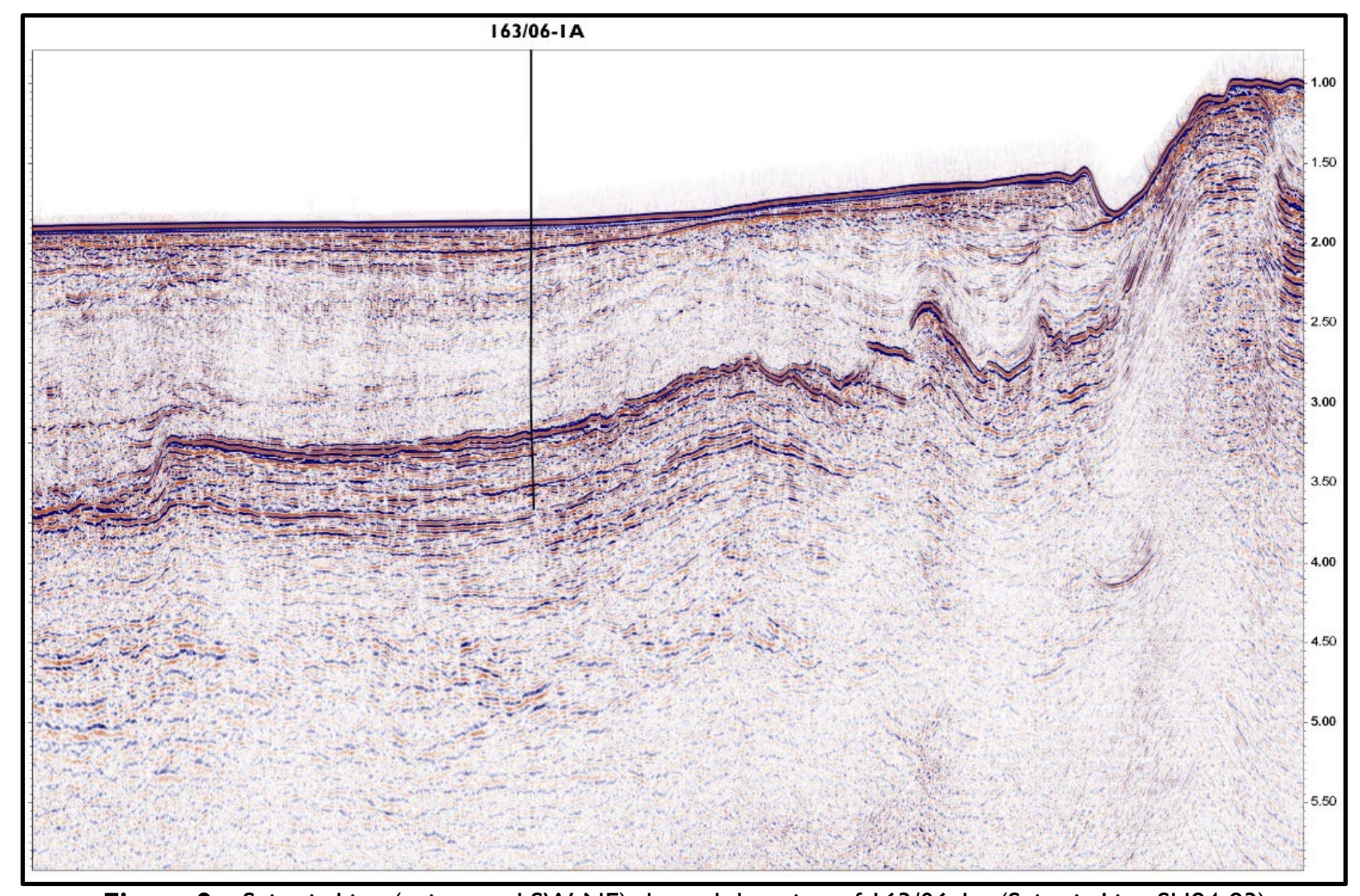

Figure 9 - Seismic Line (orientated SW-NE) through location of I63/06- Ia. (Seismic Line SH84-93) 


\section{3/06-1a}

Prognosed

(m)

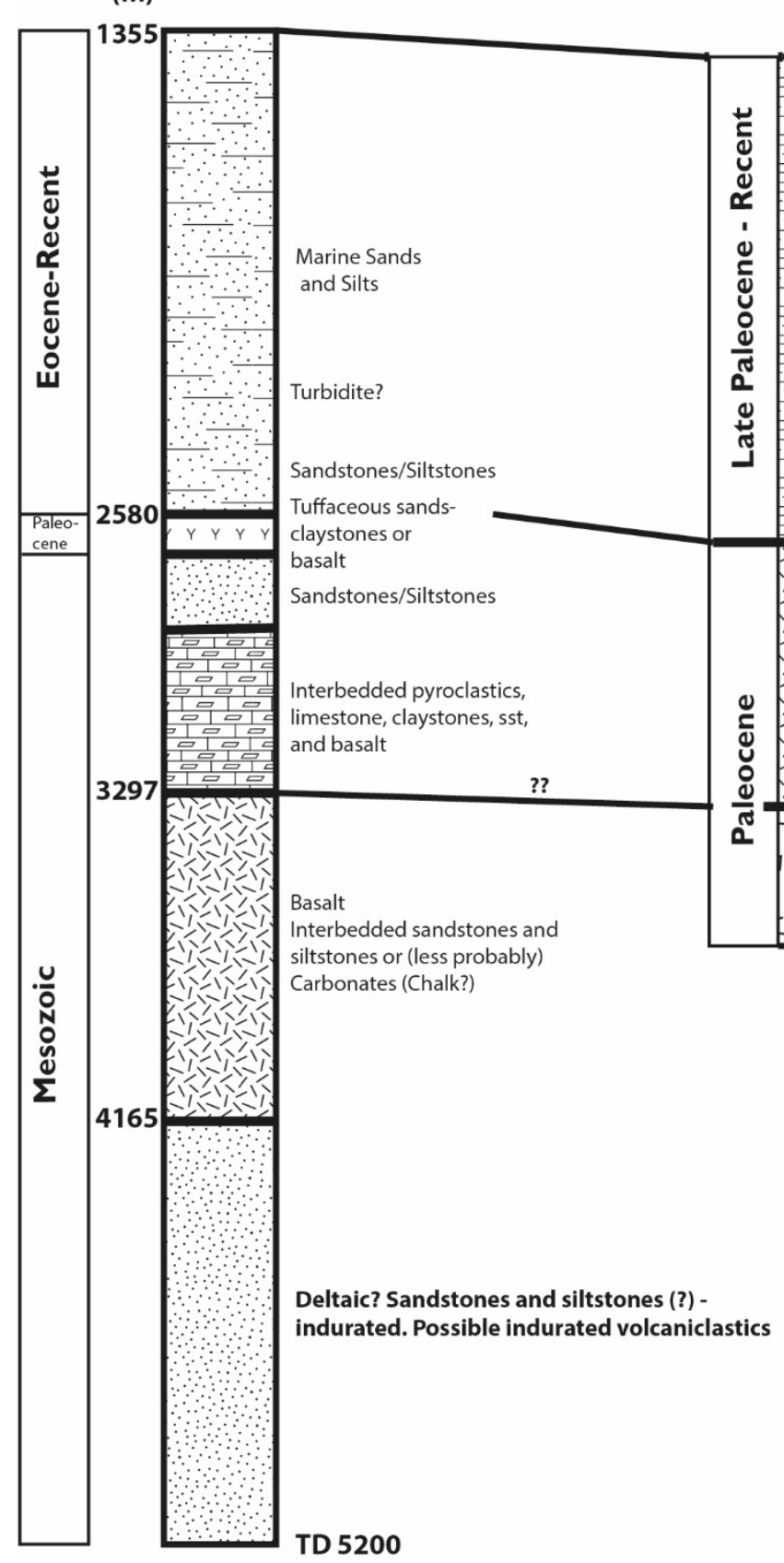

(m)

1388.6

\& Claystone

2641

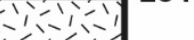

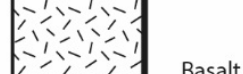

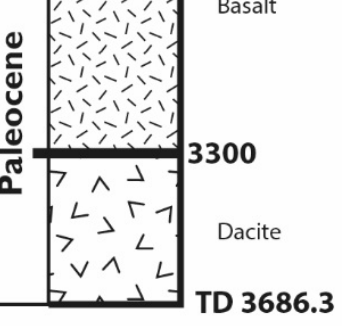

TD 3686.3

Figure 10 - Prognosed vs Actual for well I63/06-Ia. Note that the Deltaic sequence predicted to be encountered at 4 I 65 $\mathrm{m}$ was likely to have been a prograding volcanic hyaloclastite sequence. 


\section{Summary}

Well 163/06-Ia, drilled in 1980, was designed to test stratigraphy of the Rockall Basin and establish the presence of any hydrocarbon system, as up to this point, little to no subsurface information was available for the UK Rockall. The well was funded by a consortium of 19 companies (incl. BP, Chevron, Conoco, Elf, Gulf, Shell, Total, ICI), paying 49\% of costs, and BNOC, British Gas Corp and the then Department of Energy, paying $51 \%$ of costs. The primary objective of the well was to evaluate a proposed Mesozoic foreset succession (assumed to be sedimentary in origin) at $\sim 4165 \mathrm{~m}$, located beneath a prognosed extrusive volcanic sequence.

Upon drilling, the well encountered a sequence of Eocene and Paleocene siltstones before penetrating nearly I km of extrusive basalt before the well was abandoned due to drilling difficulties (Fig. 9 \& 10). Although the 'foreset' succession was not reached in the well, in hindsight, given the volcanics encountered in this well, across the basin (e.g. 164/7-I) and wider Atlantic Margin (e.g. Millett at al. 20I5), it is likely that the prognosed foreset succession was a prograding volcanic lava-hyaloclastite package, rather than any clastic sedimentary system.

\section{Structure}

None defined

\section{Shows}

No signs of hydrocarbons found in the well

\section{Reservoir}

No reservoir sequences present (Eocene and Paleocene were siltstone dominated)

\section{Seal}

None defined

\section{Potential Source Rocks}

No potential source rocks sequences were penetrated by the well

\section{Comments}

Drilled in 1980, primarily as a stratigraphic test near to the centre of the North Rockall Basin (NRB), with little to no subsurface information, well $163 / 6$ a - I provided valuable data. However, aside from establishing a broad stratigraphy of Paleocene-younger strata (Fig. 10), failure to penetrate out of the sequence of volcanics gave little to no information on sub-Paleocene stratigraphy and/or prospectivity. 
I 64/25- I, I z (Drilled I 988)

\begin{tabular}{|l|l|}
\hline Operator & BP \\
\hline Date Spudded & $3 \mathrm{I} / 07 / 88$ \\
\hline TD Date & $\mathrm{I} 3 / 09 / 88$ \\
\hline Days Drilling & 45 days (I month, I4 days) \\
\hline Type & Exploration Rank Wildcat \\
\hline Status & P\&A - Dry Hole \\
\hline Shows & None \\
\hline License & P.55I \\
\hline Latitude & $59^{\circ}$ II '45.08"N \\
\hline Longitude & $07^{\circ} 08^{`} 56 . \mathrm{I}$ I"N \\
\hline Reference Datum & ED50 \\
\hline Projection & International Spheroid \\
\hline KB (m) & 26 \\
\hline Water Depth (m) & $4 I 7$ \\
\hline TD (mRT) & 4050 \\
\hline Age at TD & Permo-Triassic \\
\hline Primary Objective & $\begin{array}{l}\text { Prognosed Early to Middle Jurassic shallow } \\
\text { marine sandstones }\end{array}$ \\
\hline Secondary Objective & $\begin{array}{l}\text { Prognosed Paleocene to Late Cretaceous } \\
\text { sandstones }\end{array}$ \\
\hline Play/Trap Style & $\begin{array}{l}\text { Prognosed as a four-way dip closed hanging- } \\
\text { wall anticline (see below) }\end{array}$ \\
\hline Objectives Fulfilled & $\begin{array}{l}\text { Jurassic absent, but good quality reservoir } \\
\text { horizons encountered in Paleocene. }\end{array}$ \\
\hline Reason for Failure & $\begin{array}{l}\text { Stated as lack of source presence and } \\
\text { maturity }\end{array}$ \\
\hline Notable Aspects & $\begin{array}{l}\text { Paleocene strata contained } \\
\text { quantity of reworked late Jurassic mudstone }\end{array}$ \\
\hline & \\
\hline
\end{tabular}

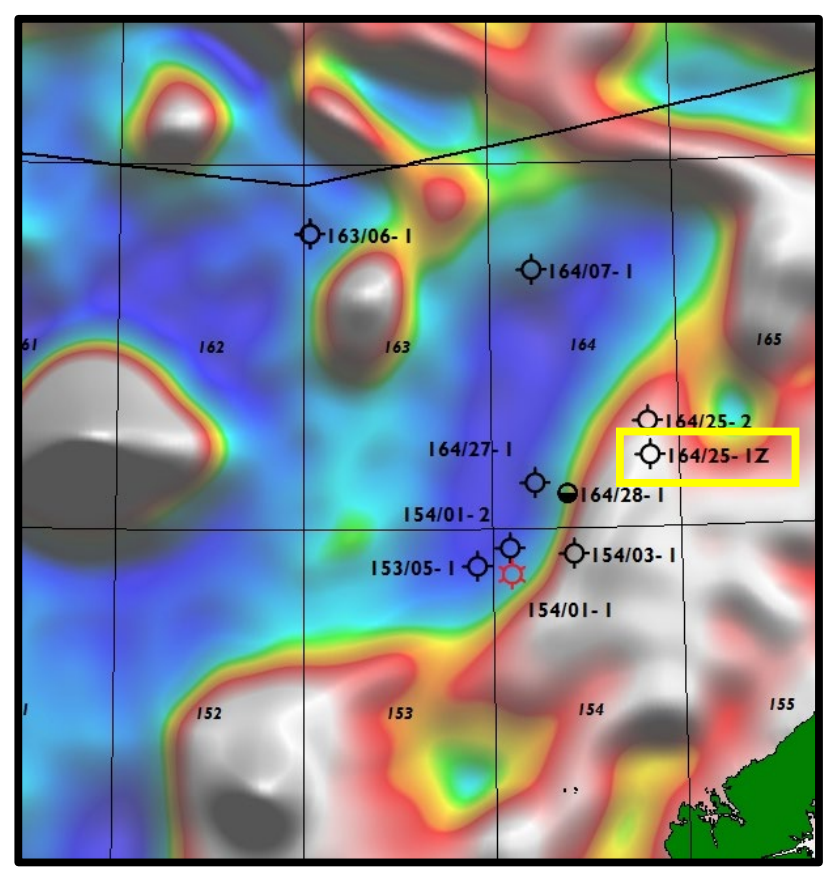




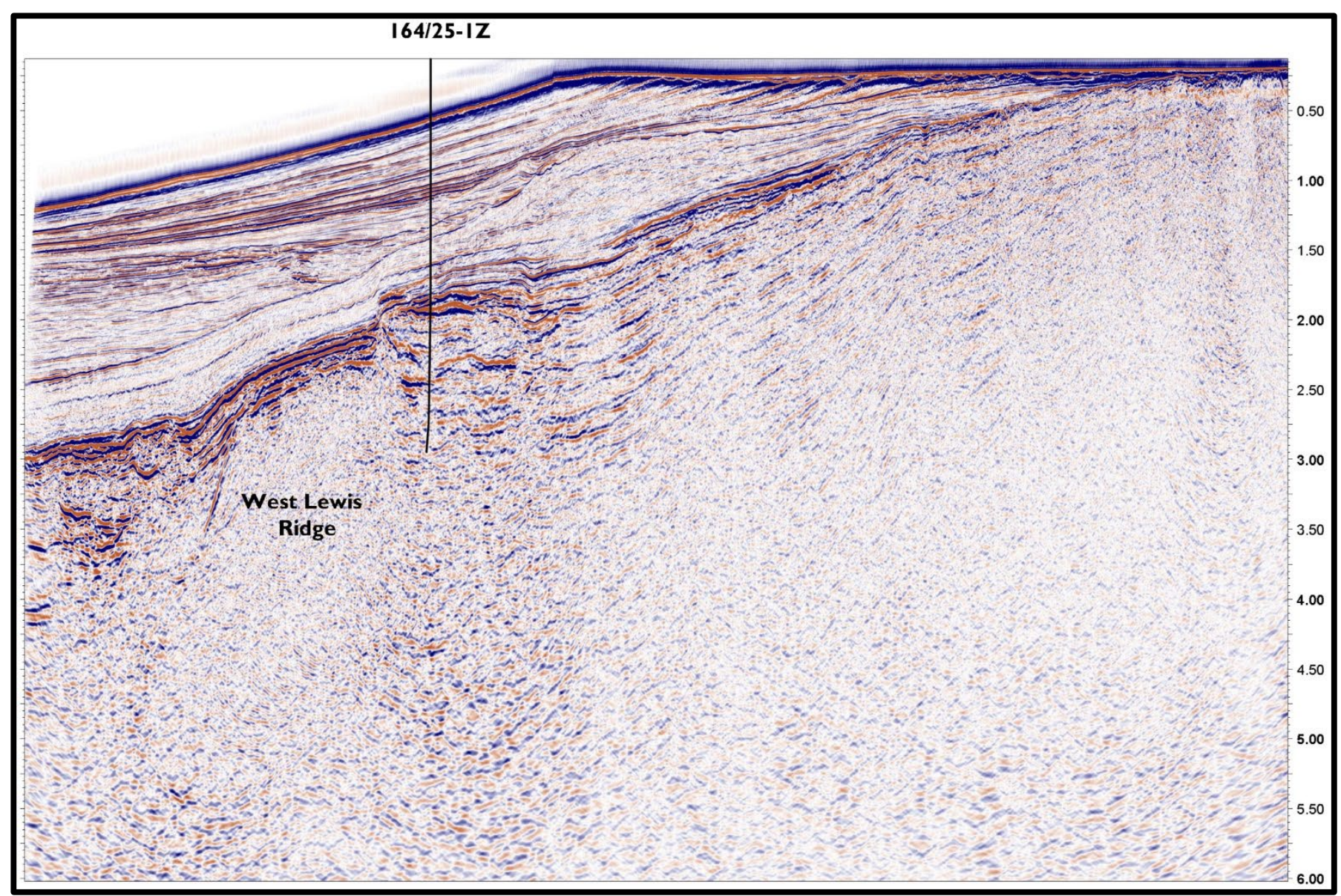

Figure I I - Seismic Line (orientated NW - SE) across West Lewis Ridge and location of well I64/25-I, Iz (OGA 2015 Seismic line 28)

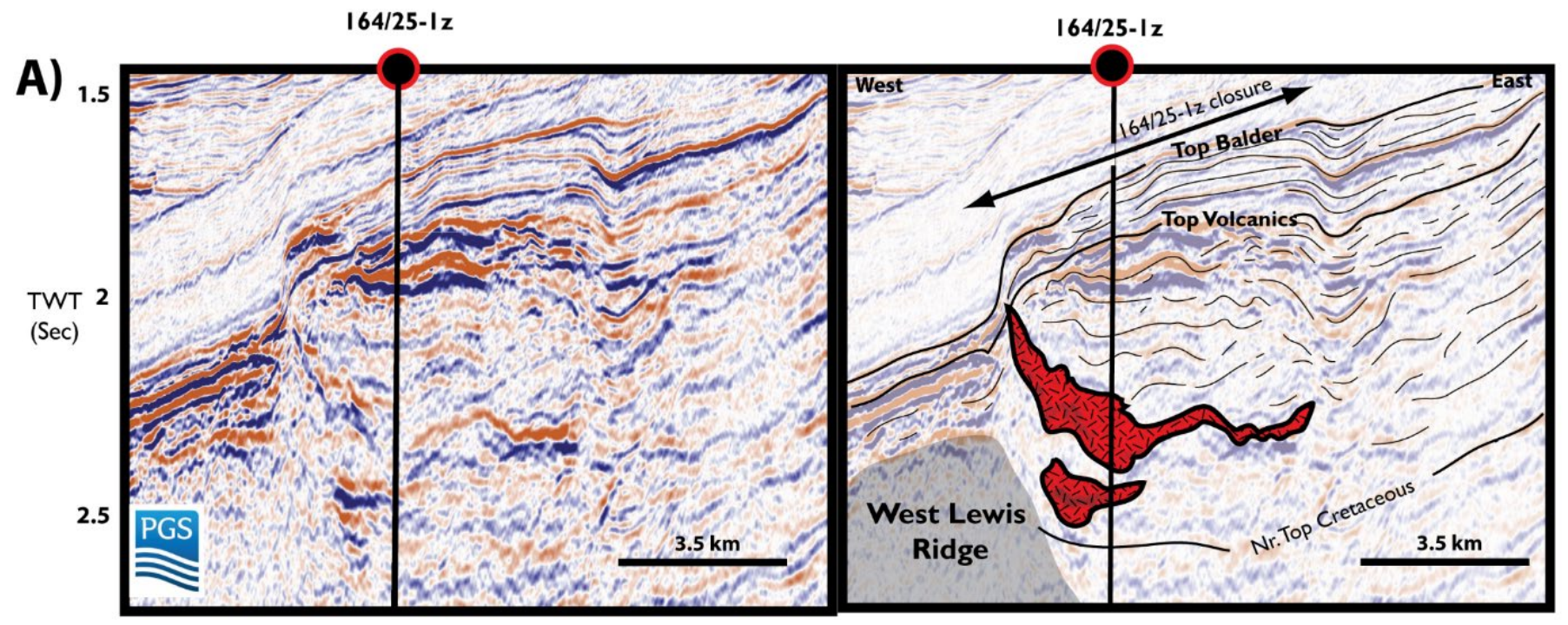

Figure 12 - From Schofield et al. (2018) showing dip-closed structure targeted by 164/25-Iz. Note the occurrence of underlying intrusions under the closure 
$164 / 25-1 z$

Prognosed

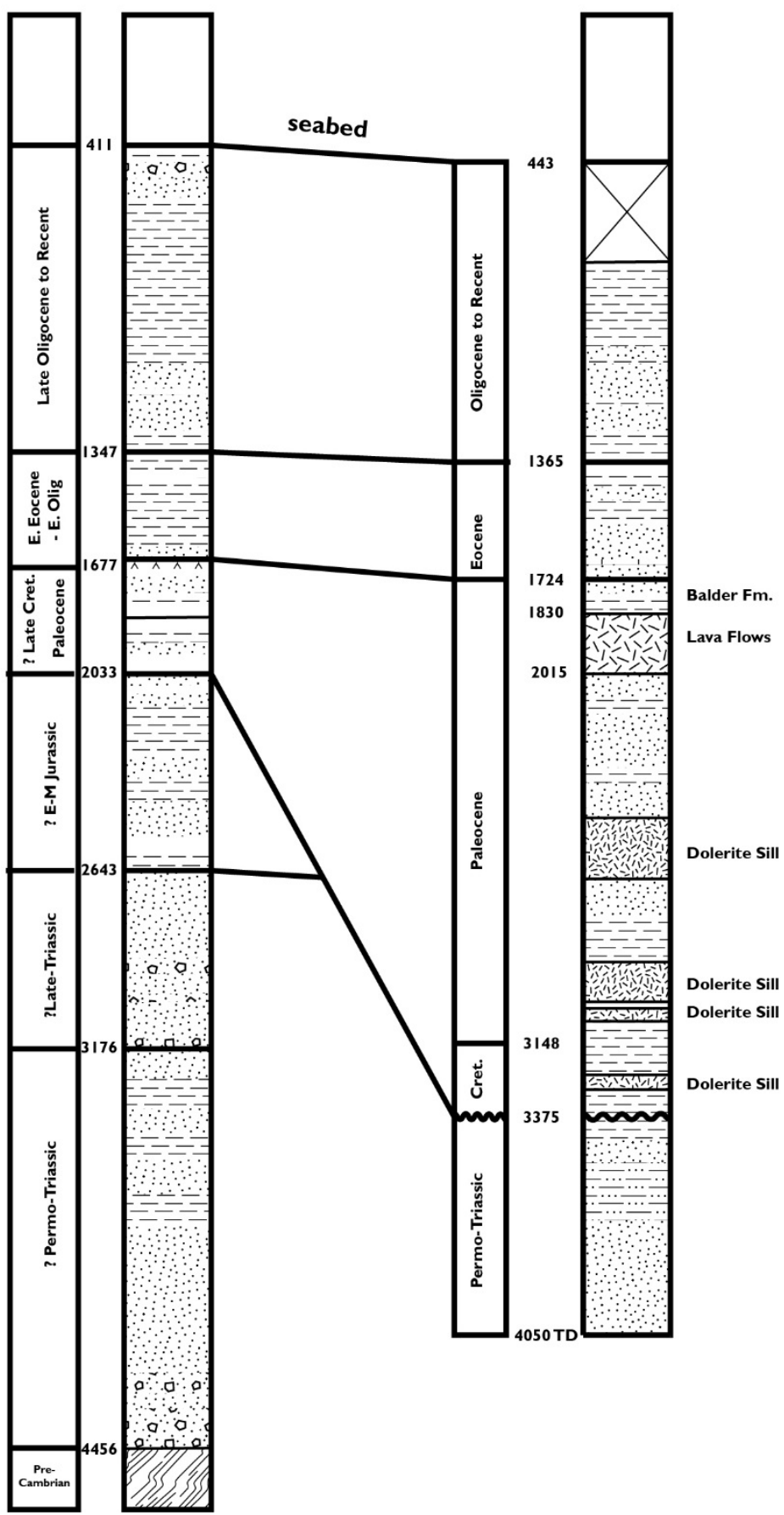

Figure 13 - Prognosed vs Actual for well 164/25-Iz. Note the lack of the prognosed Jurassic sequence 


\section{Summary}

Well 164/25-I,Iz, drilled in 1988, was drilled by BP to target a four-way dip closure located to the east of the faulted high of the West Lewis Ridge (Fig. II \& 12). At the time of drilling, the nearest wells were located 130 and $190 \mathrm{~km}$ away, which led to a highly speculative pre-drill stratigraphic prognosis. Upon drilling, the well penetrated a series of Paleocene and Eocene sedimentary strata, before entering an extrusive volcanic sequence. The well then encountered a series of Lamba Fm. and Vaila Fm. equivalent sequences, before penetrating into the Cretaceous. Importantly, the Cretaceous was found to be unconformably overlying the Permo-Triassic (Fig. 13).

\section{Structure}

The four way-dip closure penetrated by $164 / 25-\mathrm{I}$, Iz, was interpreted prior to drilling as a hanging-wall anticline developed over a Palaeogene aged-inversion structure on the West Lewis Ridge. New data over I64/25-I, Iz shows a four-way closure underlain by saucer-shaped intrusions, which were also penetrated by the well (Fig. 12). The closure of the structure conforms to the underlying intrusions, and the nature of folding and closure closely matches that seen in other forced folds documented along the Margin (e.g. FSB: Schofield et al. 20I5), and previously interpreted in Rockall (Hansen and Cartwright, 2006). We therefore interpret that the closure penetrated by $164 / 25-\mathrm{I}$, Iz was mainly created by the underlying intrusions jacking up the overlying sequences, with additional inversion against the West Lewis Ridge. It is noteworthy that within the geological well evaluation report produced after the well was completed, a reference is made that the sills penetrated in the well were 'invoked as the possible cause for the inversion feature' as a result of 'jack-up'.

\section{Shows}

A minor show was reported 1977-1985 m in the well. However, there was no change in background gas or wireline logs over interval, and the show was interpreted as a result of mineral fluorescence. Re-analysis of wireline data potentially indicates minor traces of hydrocarbons within the sands of the Balder Fm. (pers. comms. Dr Clayton Grove, Siccar Point Energy)

\section{Reservoir}

The well penetrated several Vaila Fm. equivalent turbiditic sandstones. Cores taken from the interval demonstrated moderate to good quality of the sandstones, with mean porosity of $22.3 \%$ and permeability of $135.6 \mathrm{mD}$.

\section{Seal}

The Paleocene-Recent section was sand dominated; however, the section does contain a number of intraformational shales and mudstones. The Cretaceous marine mudstone provided a viable sealing lithology.

\section{Potential Source Rocks}

The well penetrated no potential source rock horizons. Significantly, the Cretaceous was found to unconformably overlie the Permo-Triassic, with no Jurassic strata present (Fig. I3). Arguably, the lack of a Jurassic succession overlying the Permo-Triassic within this well is a key finding that triggered the first doubts within the UK Rockall Basin concerning the presence and areal extent of Jurassic source rocks West of Hebrides.

Importantly, however, large quantities of organic mudstone were found reworked within the Paleocene and Early Eocene sandstones in the well (Fig. 14). Core 3 (2646.2 - 2663.3) taken from the Paleocene Vaila Fm. equivalent sequences contained mudstone clasts of up to $30 \mathrm{~cm}$ 's, interpreted to be 
of Kimmeridgian equivalent (although the clasts were found at the time to be barren of definitive age diagnostic taxa). The presence of the clasts does, however, suggest that Jurassic sequences were present in the 'relative' vicinity of the location of well $164 / 25-\mathrm{I}$, Iz, but were likely being actively eroded off basement highs (West Lewis Ridge and/or Outer Hebrides High?) during the Paleocene.

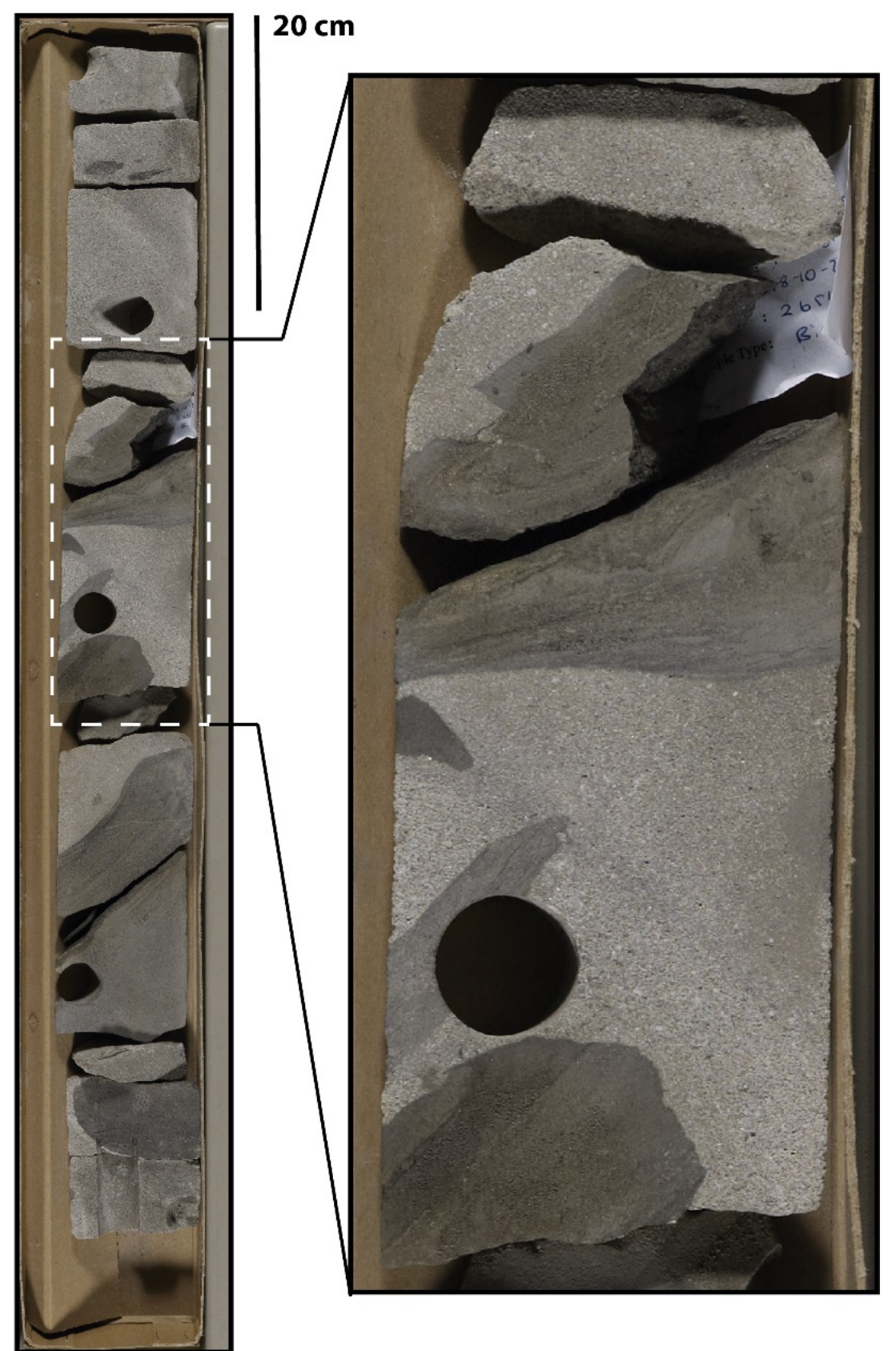

Figure 14 - Section of Core 3 (2646.2 - 2663.3) from Well I64/25-I taken from Vaila Fm. equivalent turbiditic sandstones, showing inclusion of mudstone clasts. Photo from BGS online core photos

\section{Comments}

Well 164/25-I, Iz represents the first valid test of the petroleum system West of Hebrides. However, the well is actually not a true test of the petroleum systems of the main deep-water UK Rockall Basin, but rather the westerly extent of the West Lewis Basin, which is an intra-shelf basin of the Outer Hebrides High (Fig. 3). Importantly, the well is also currently the only exploration well within the Rockall that penetrates sedimentary strata older than the Cretaceous (aside from wells that entered directly into Precambrian basement). 


\section{64/25-2 (Drilled I990)}

\begin{tabular}{|c|c|}
\hline Operator & $\mathrm{BP}$ \\
\hline Date Spudded & $25 / 07 / 1990$ \\
\hline TD Date & $18 / 08 / 1990$ \\
\hline Days Drilling & 24 \\
\hline Type & Exploration \\
\hline Status & P\&A - Dry \\
\hline Shows & None \\
\hline License & P.55I \\
\hline Latitude & $59^{\circ} 17^{\prime} 20.01 \mathrm{~N}$ \\
\hline Longitude & $07^{\circ} 08^{\prime} 42.18 \mathrm{~W}$ \\
\hline Reference Datum & ED50 \\
\hline Projection & International Spheroid \\
\hline $\mathrm{KB}(\mathrm{m})$ & 26 \\
\hline Water Depth (m) & 696.5 \\
\hline TD (mRT) & 2728 \\
\hline Age at TD & Precambrian (Crystalline Basement) \\
\hline Primary Objective & $\begin{array}{l}\text { To evaluate the Pre-Rift succession to } \\
\text { investigate source and reservoir intervals }\end{array}$ \\
\hline Secondary Objective & - \\
\hline Play/Trap Style & Fault block \\
\hline Reason for Failure & $\begin{array}{l}\text { Invalid geological target - The 'Pre-rift } \\
\text { succession' was found to be Precambrian } \\
\text { basement }\end{array}$ \\
\hline Notable Aspects & $\begin{array}{l}\text { The well penetrated } \sim 150 \mathrm{~m} \text { of Colsay Sst } \\
\mathrm{fm} \text {. equivalent intra-lava clastics. This raises } \\
\text { the possibility of an intra-basaltic Rosebank- } \\
\text { type play within Rockall (see Schofield et al. } \\
2018 \text { ) }\end{array}$ \\
\hline
\end{tabular}

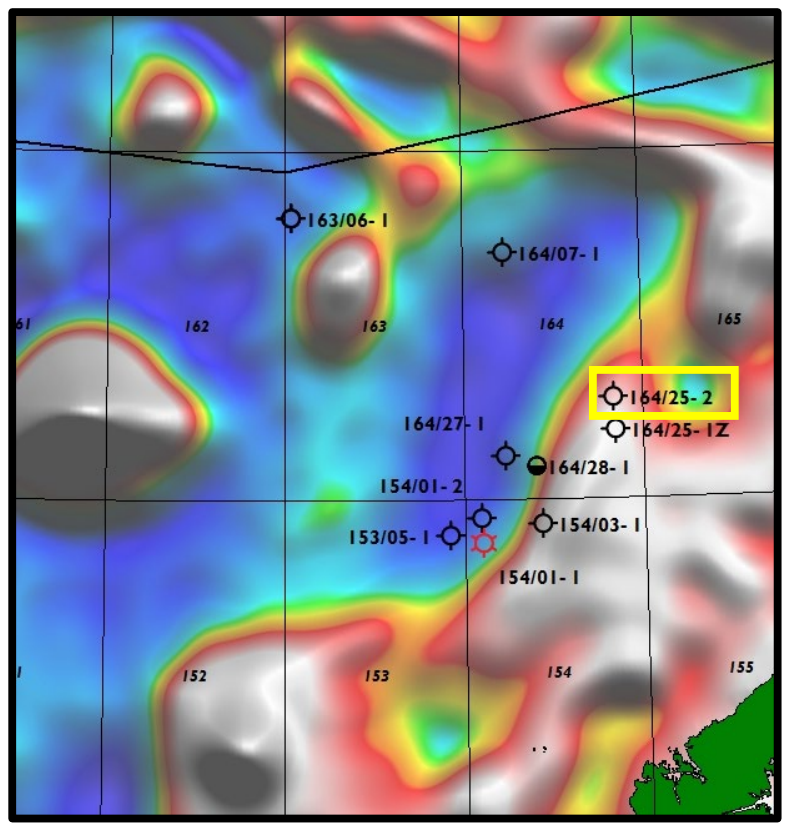




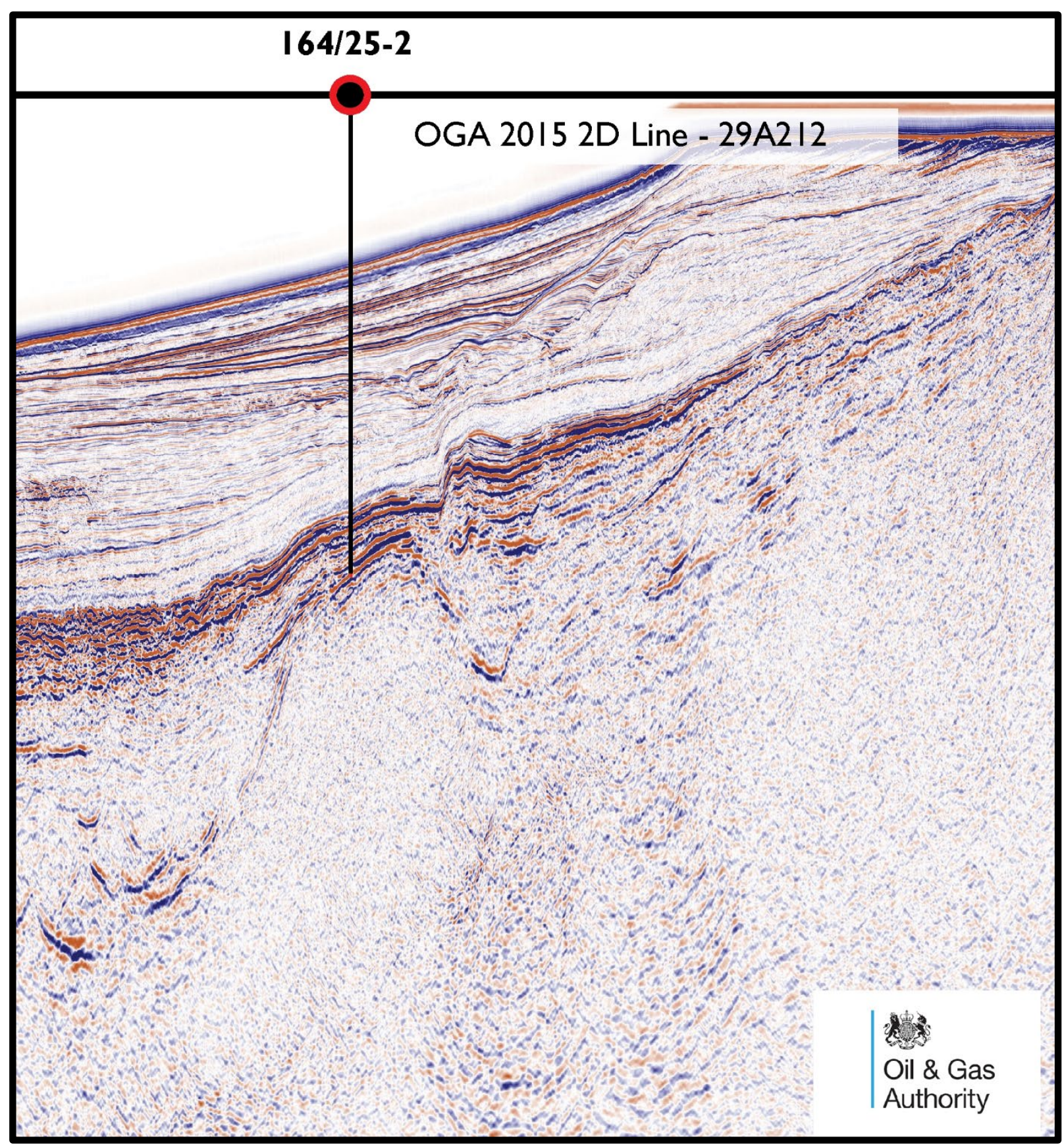

Figure 15 - Seismic Line from Schofield et al. (2018) orientated (NW-SE) through well 164/25-2 drilled atop the West Lewis Ridge, $\sim 10 \mathrm{~km}$ north of $164 / 25-\mathrm{I}, \mathrm{Iz}$ 
$164 / 25-2$

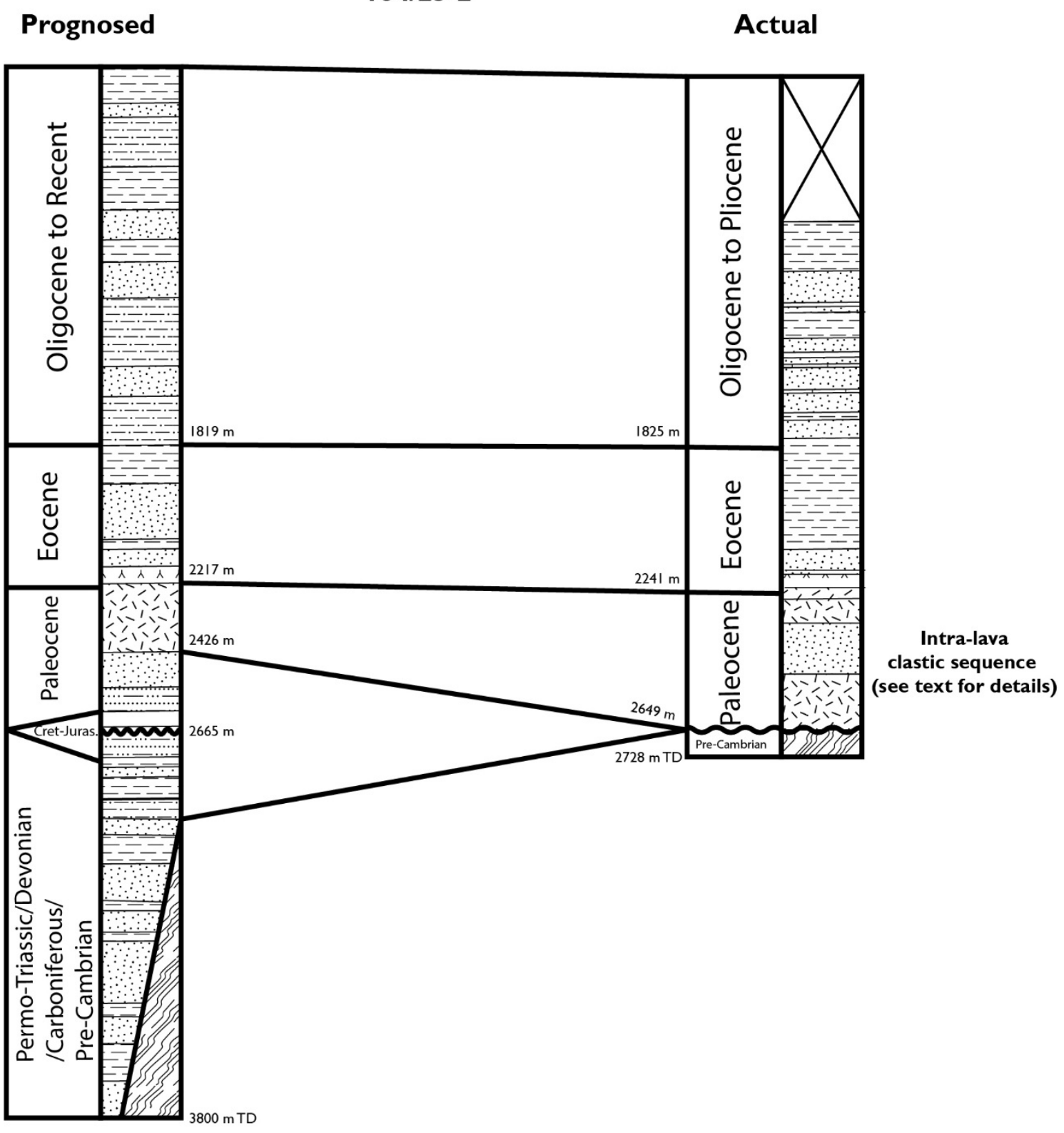

Figure 16 - Prognosed vs Actual for well 164/25-2. The primary target of the wells was the prognosed pre-rift sequence of Permo-Triassic to Carboniferous. However, upon drilling, the 'pre-rift' target was found to be Lewisian basement 


\section{Summary}

Well 164/25-2, drilled in 1990, represented BP's second well (out of a three well commitment) within the UK Rockall area, and was drilled $10 \mathrm{~km}$ to the north of well $164 / 25-1, \mathrm{lz}$. The well was designed to test the hydrocarbon potential of pre-rift deposits in the Northern Rockall area. However, the well, which was located atop the West Lewis Ridge (Fig. 15), after encountering a thick $(\sim 400 \mathrm{~m})$ sequence of Palaeocene lavas and intra-volcanic clastic sequences, penetrated directly into crystalline Lewisian basement, with no 'pre-rift' clastic sequence present (Fig. 16).

\section{Structure}

The well targeted the faulted structural high of the West Lewis Ridge.

\section{Shows}

No shows

\section{Reservoir}

At the time of drilling, well 164/25-2 provided a key well for defining the detail and maximum flooding surfaces and stratigraphy of the Palaeocene sequences within the UK Rockall area. The well penetrated a $150 \mathrm{~m}$ clastic sequence between the lava sequences (Fig. 16), which was classified within the well data as being equivalent to Sequence T36-38 Lamba Fm. However, as of 2018, and in view of the exploration and appraisal of intra-lava sequences of the Rosebank Field within the Faroe-Shetland basin, it is possible to undertake a biostratigraphical correlation, and place the sequence in a correct stratigraphic context.

Biostratigraphic correlation between the Rosebank intra-lava sequences (well 213/27-2) and the intra-lava 164/25-2 importantly shows that intra-lava unit penetrated by 164/25 -2 is not Sequence T36T38 Lamba Fm. in age, but is likely a Sequence T40 Flett Fm. Colsay member equivalent interval, chronostratigraphically equivalent to the reservoir sequences which form Rosebank (Fig. 17).

Interestingly, it should be noted that the $150 \mathrm{~m}$ thickness of clastic rich Colsay Mbr equivalent strata penetrated by $164 / 25-2$ is considerably thicker than any individual Colsay packages penetrated within the Rosebank Field, which are in the region of 10's of metres and interbedded with lava flows. Additionally, in common with the Colsay Mbr of Rosebank, excellent porosity of up to $35 \%$ and permeabilities of over $8 \mathrm{D}$ are present in this sequence within 164/25-2.

\section{Seal}

The complete lack of hydrocarbon shows within any of the drilled post-lava sequences, which did contain limited reservoirs sequences, led BP to postulate at the time that the lava sequences were acting as effective seals, preventing migration into post-lava sequences.

\section{Potential Source Rocks}

The well recorded no potential source rock horizons. 


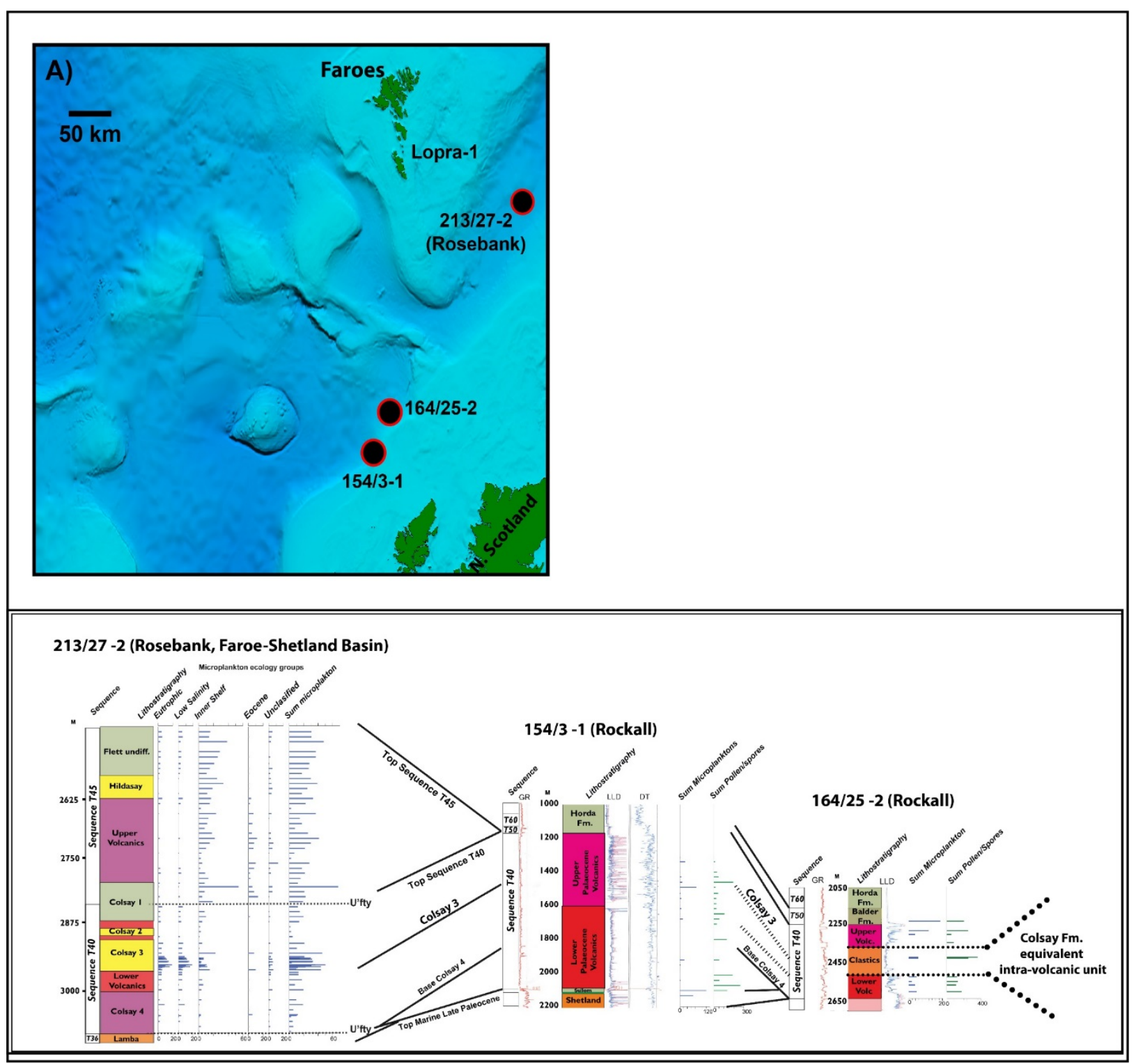

Figure 17 - Faroe-Shetland to Rockall Basin biostratigraphic correlation of Colsay Fm. equivalent units. Modified from Schofield et al. (2018) 


\section{I32/I5-I (Drilled I99 I)}

\begin{tabular}{|c|c|}
\hline Operator & $\mathrm{BP}$ \\
\hline Date Spudded & $21 / 04 / 1991$ \\
\hline TD Date & $04 / 06 / 1991$ \\
\hline Days Drilling & 45 days (I month, I5 days) \\
\hline Type & Exploration \\
\hline Status & P\&A - Dry Hole \\
\hline Shows & None \\
\hline License & P.286 \\
\hline Latitude & $56^{\circ} 36^{\prime} 45.26^{\prime \prime} \mathrm{N}$ \\
\hline Longitude & 0909'08.09” W \\
\hline Reference Datum & ED50 \\
\hline Projection & International Spheroid \\
\hline $\mathrm{KB}(\mathrm{m})$ & 28.85 \\
\hline Water Depth (m) & 707 \\
\hline TD (mRT) & 4150 \\
\hline Age at TD & Precambrian (crystalline basement) \\
\hline Primary Objective & $\begin{array}{l}\text { To test hydrocarbon potential of large pre- } \\
\text { rift tilted fault block }\end{array}$ \\
\hline Secondary Objective & Additional targets in Syn to Post-rift section \\
\hline Play/Trap Style & Tilted fault block \\
\hline Reason for Failure & $\begin{array}{l}\text { Invalid Geological Target. Pre-rift of primary } \\
\text { target was found to be crystalline basement. } \\
\text { Syn-rift (Cretaceous) contained no reservoir } \\
\text { sequences. Post-rift (Paleocene-Eocene) } \\
\text { sandstones showed no hydrocarbons or } \\
\text { shows. }\end{array}$ \\
\hline Notable Aspects & $\begin{array}{l}\text { The Vaila Fm. equivalent section contained a } \\
50 \mathrm{~m} \text { thick volcaniclastic sandstone, } \\
\text { indicating potential sourcing of material from } \\
\text { the lgneous centres of the West Coast of } \\
\text { Scotland. }\end{array}$ \\
\hline
\end{tabular}

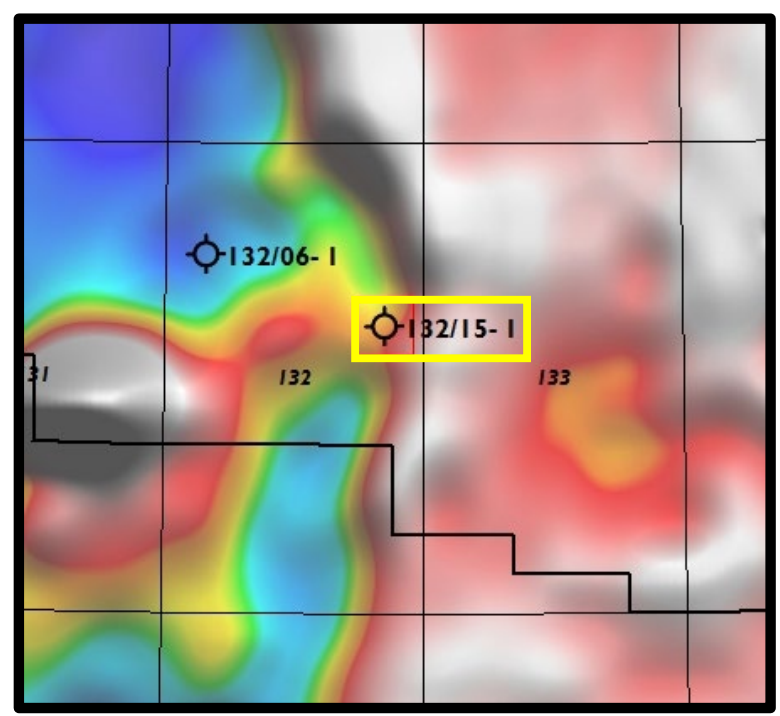



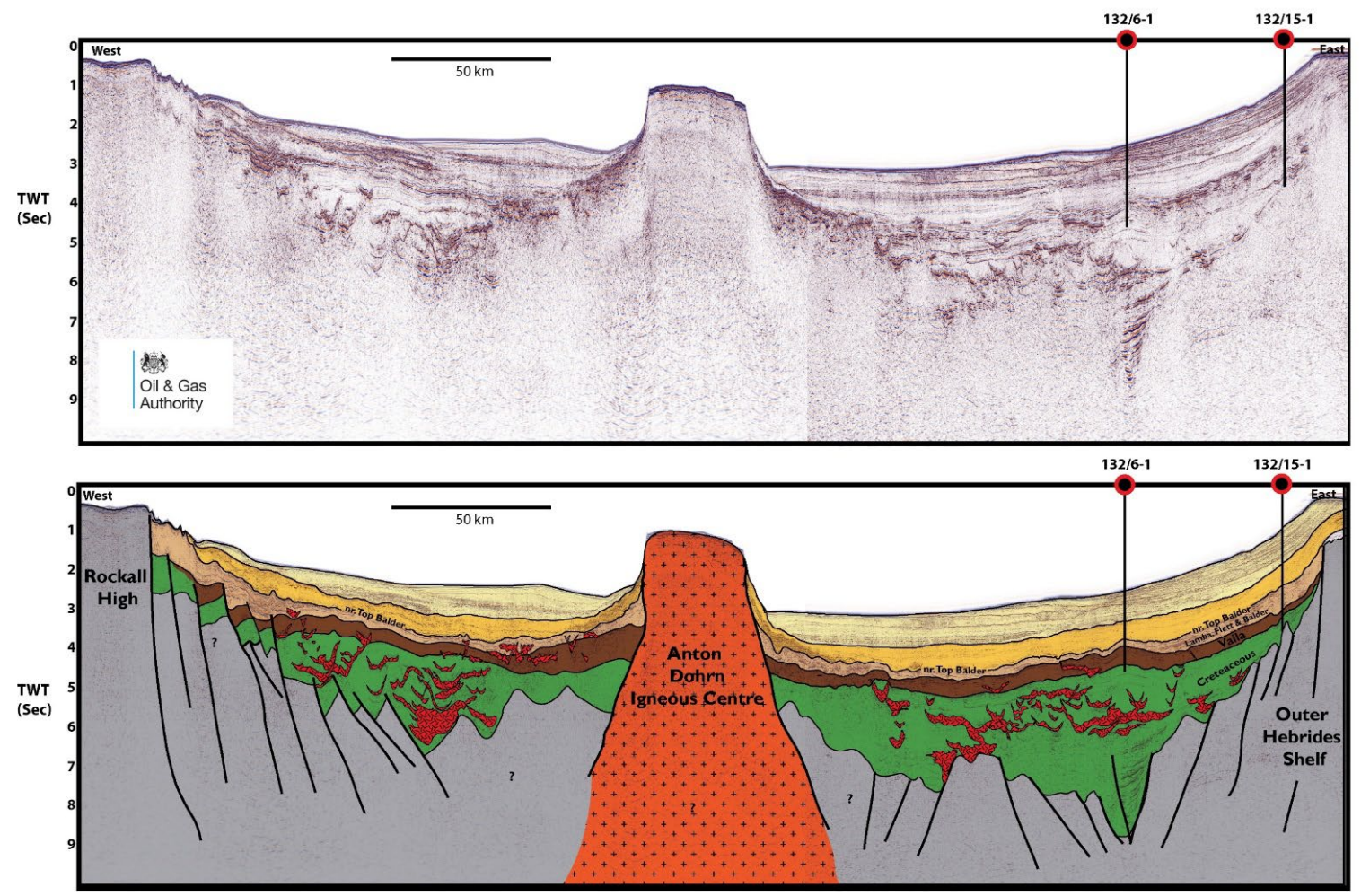

Figure 18 - From Schofield et al. (2018) showing West-East orientated seismic line across the southern UK Rockall Basin and location of I32/I5-I and I32/6-I

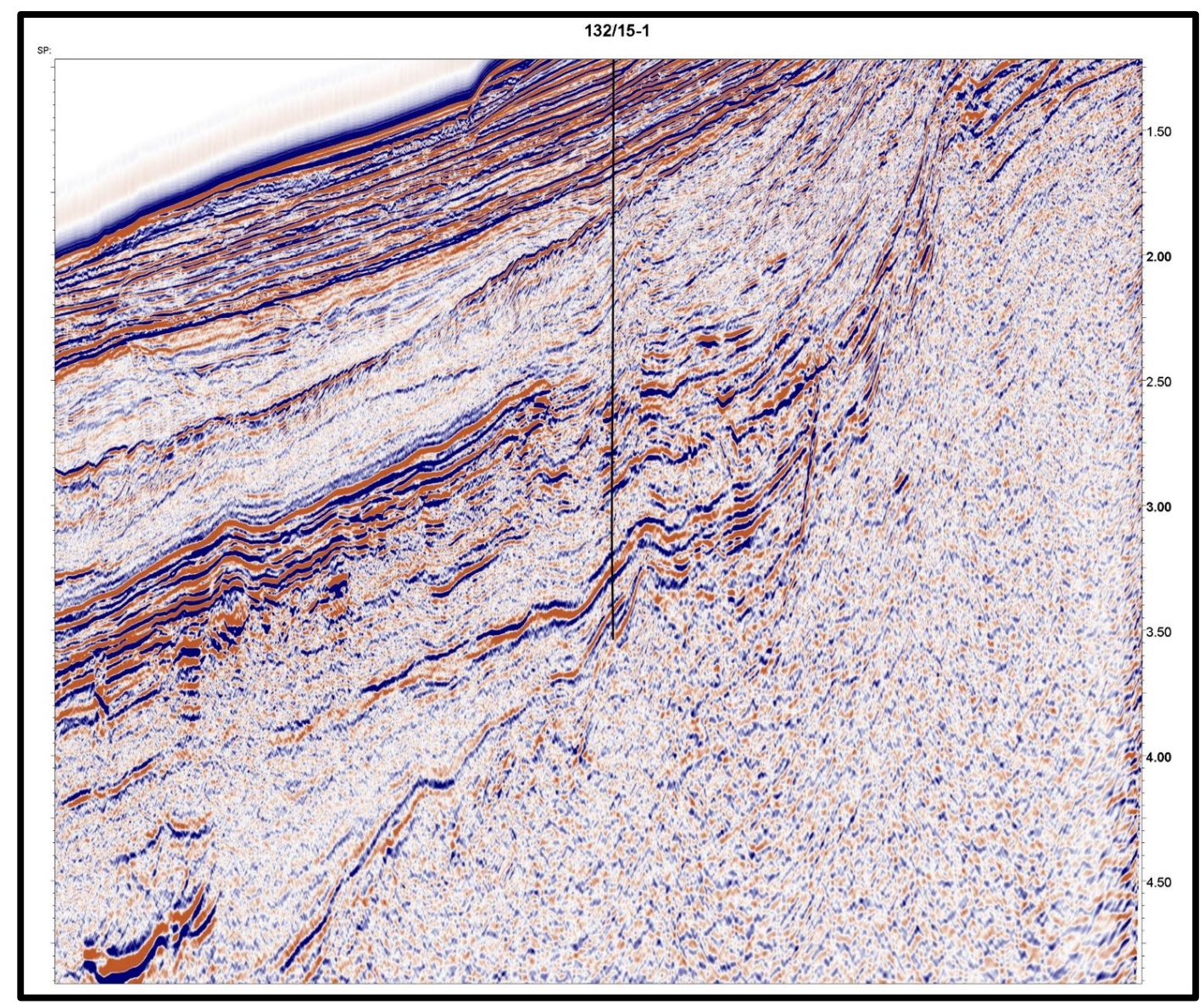

Figure 19 - Seismic line (orientated NW-SE) through well I32/I5-I. (OGA 2015 Line 32) 


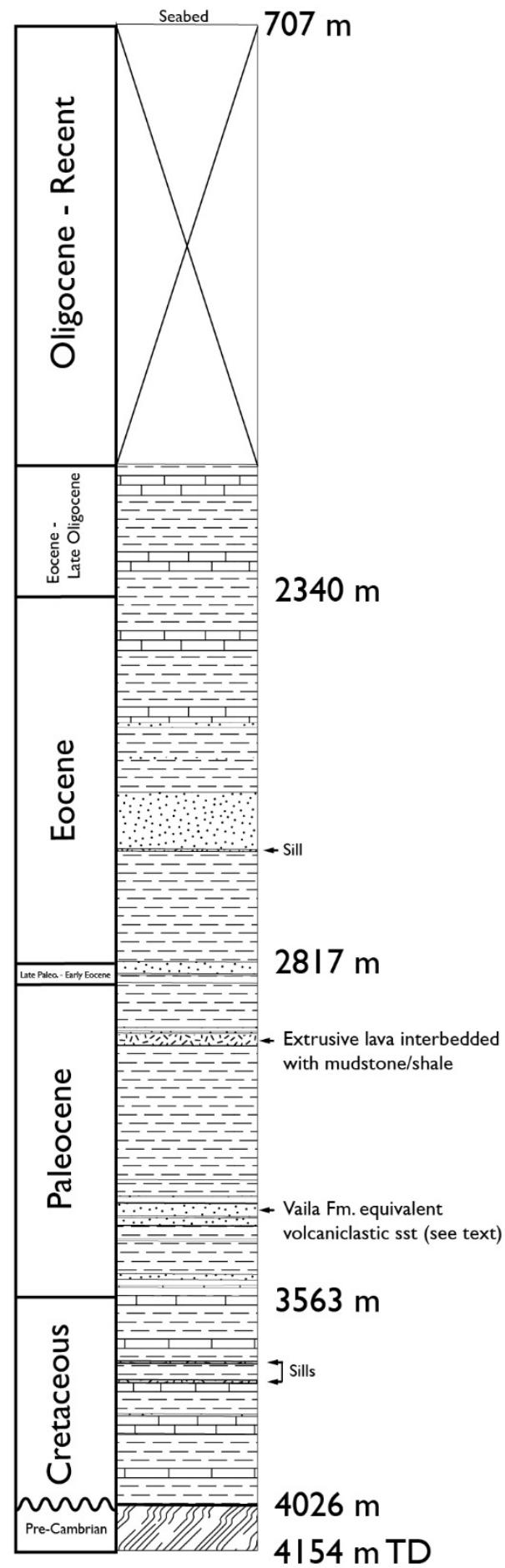

Figure 20 - Stratigraphic summary of I32/I5-I 

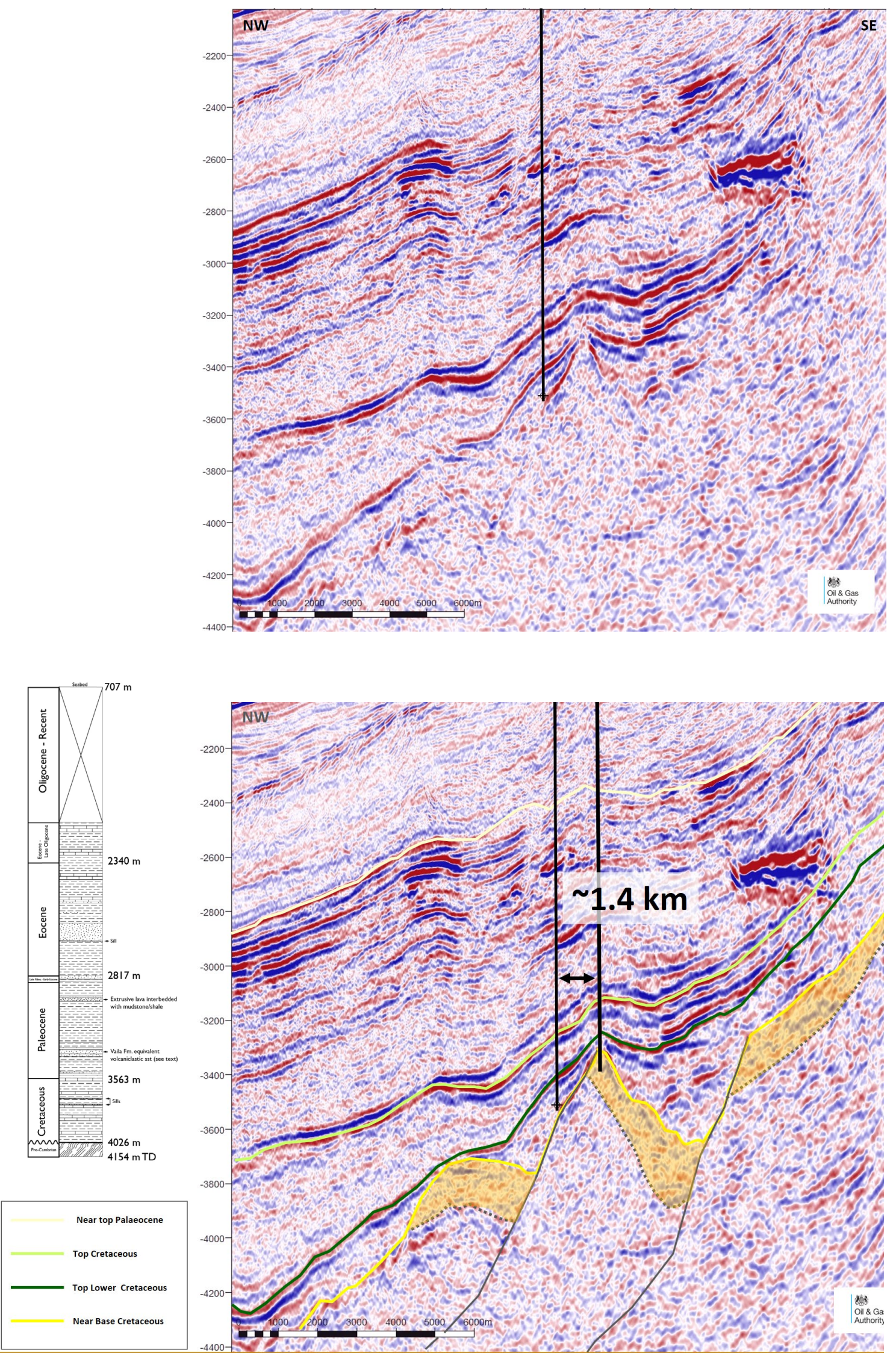

Figure 2I - Well I32/I5-I penetrated through Cretaceous sequence, before entering into Precambrian basement, of which the top of the basement sequence $(4037-4079 \mathrm{~m})$ was described as fractured. A $50 \mathrm{~cm}$ core taken at $4147 \mathrm{~m}$, also shows extensive fracturing, mineral filled veins, and evidence of cataclasite. It would appear that the reason for the well finding no pre-rift sequence, and then encountering fractured basement, is that the well appears to have been drilled into the footwall fault scarp, and missed the pre-rift section atop of the fault block by approximately $1.4 \mathrm{~km}$ 


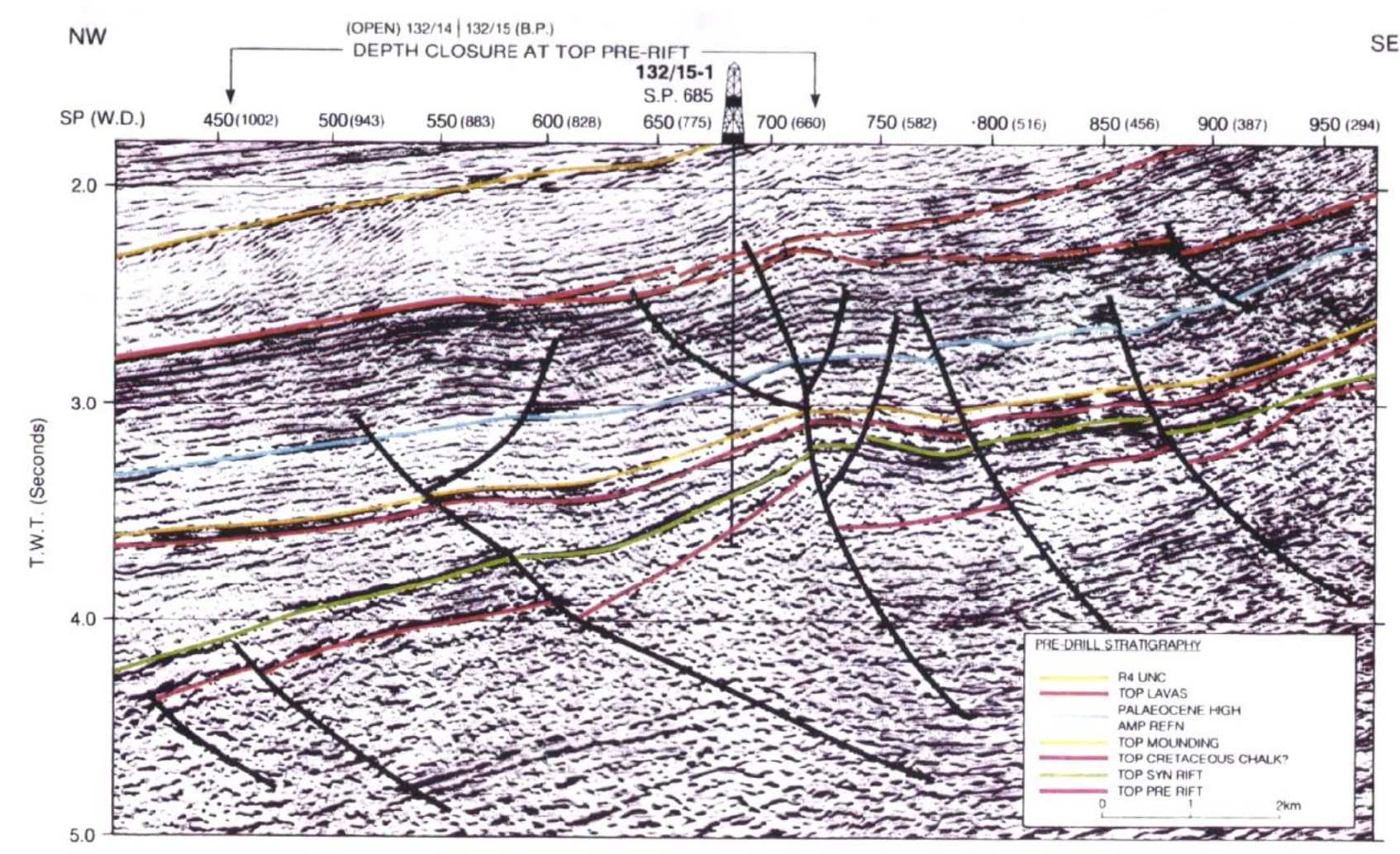

Figure 22 - Seismic line from BP well document showing pre-drill interpretation and quality of data used to site well 132/I5I. Line is same orientation (NW-SE) as that in Fig. 19 \& 21 . Note the different polarity of fault orientations 


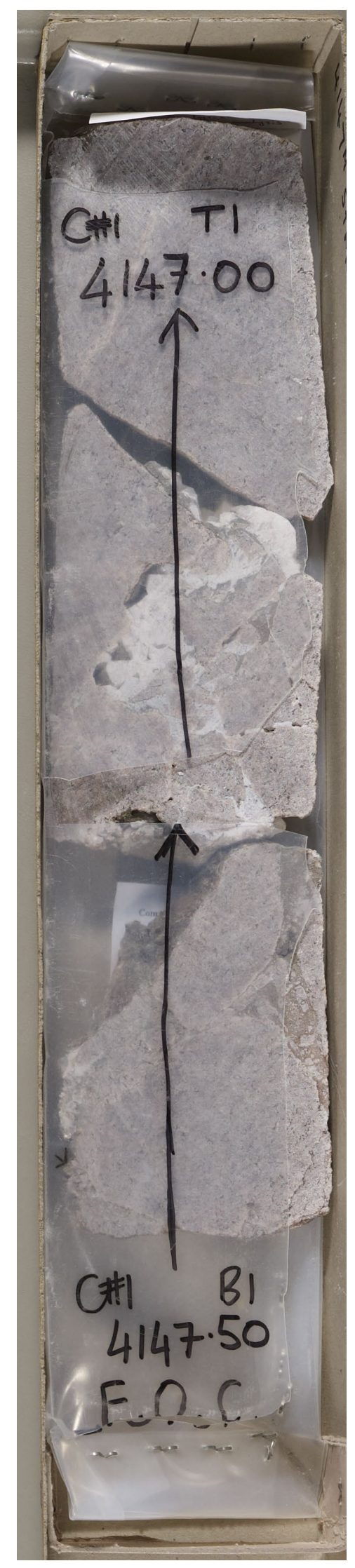

Figure 23 - A $50 \mathrm{~cm}$ core taken from Precambrian section of well I32/I5-I. Note extensive fracturing, vein infilling and cataclasite. (Photo from BGS core photos) 


\section{Summary}

Well 132/I5-I, drilled in 1991 by BP, was the last of a three well commitment in the Rockall Basin. The well was designed to test the hydrocarbon potential of a large pre-rift tilted block and other secondary syn- and post-rift targets (Fig. 18 \& 19). The well formed the first test of hydrocarbon viability of the southern extent of the UK Rockall (Fig. 18), with the nearest offset well-being $85 \mathrm{~km}$ to the south in Irish waters. Upon drilling, the pre-rift block was found to comprise of crystalline Lewisian basement, overlain by Cretaceous strata, with no occurrence of older strata (e.g. Jurassic, Carboniferous, Devonian) (Fig. 20). However, wrong well placement due to poor quality seismic data may have led to the well missing its target by $\sim 1.4 \mathrm{~km}$ (Fig. 21 \& 22) (see comments below). No hydrocarbons or shows were encountered in the post rift sequences, and no reservoirs rocks where found within the Cretaceous megasequence, which comprised mainly of mudstone with occasional limestone sequences and intrusive sills.

Within the Vaila Fm. equivalent section, a 50 m thick volcaniclastic sandstone was encountered that was reported to contain pebbles of granite, felsite and basalt. This indicates potential sourcing of material from the igneous centres of the Inner Hebrides. Emplacement of the Rum and Arran central complexes occurred during Vaila times, with other igneous centres (e.g. Skye and Mull) emplacing during later Lamba Fm. times. Therefore, this implies that for the volcanic material to be entrained within Vaila Fm. turbidites, extremely rapid unroofing and erosion of the Rum and Arran area must have occurred immediately after emplacement of the igneous centres.

\section{Structure}

Large tilted fault block

\section{Shows}

No sign of hydrocarbons found in the well

\section{Reservoir}

Cretaceous syn-rift encountered contained no reservoir sequences, being composed of predominant mudstone with occasional limestone. Sand sequences occurred within the Paleocene-Eocene,

\section{Seal}

The tilted fault block was overlain by mudstone rich Cretaceous sequence

\section{Potential Source Rocks}

No potential source rock sequences were penetrated by the well

\section{Comments}

Well 132/I5-I marked the end of a disappointing exploration campaign for BP within the Rockall area and subsequent exit from the basin, however, the data provided important stratigraphic and subsurface knowledge of the area. The extensive post-well analysis carried out on the three BP wells should be commended and undoubtedly aided the second phase of more targeted exploration to take place in the UK Rockall from 2000-2006.

Importantly, acquisition of new seismic data (OGA line 32) (Fig. 2I), which has allowed better definition of reflectors and the basement, indicates that I32/I5-I may have actually targeted the footwall scarp, entering directly into fractured Lewisian basement at the base of the Cretaceous (Fig. 23). The crest of the structure and potential pre-rift strata (Jurassic-Older) appears to be located $\sim 1.4 \mathrm{~km}$ to the SE of the well location (Fig. 2I). 
The complete lack of any form of hydrocarbon shows, even in the form of a migrant oil show within the Eocene-Paleocene sand bodies is concerning, given the location of the well on the eastern basin margin. This can be potentially interpreted as I) No source rock to charge the sands or 2) That no viable migration route existed into the Eocene-Paleocene sand bodies shed off from Hebridean platform, which may have been stratigraphically isolated within the surrounding claystone/mudstone sequence. 


\section{I54/3-I (Drilled in I99 I)}

\begin{tabular}{|c|c|}
\hline Operator & Conoco \\
\hline Date Spudded & $29 / 05 / 1991$ \\
\hline TD Date & $3 / 07 / 1991$ \\
\hline Days Drilling & 35 days (I month, 4 days) \\
\hline Type & Exploration \\
\hline Status & P\&A - Dry Hole \\
\hline Shows & None \\
\hline License & P.550 \\
\hline Latitude & $58^{\circ} 55^{\prime} 54.12^{\prime \prime} \mathrm{N}$ \\
\hline Longitude & $07^{\circ} 33^{\prime} 53.65^{\prime \prime} \mathrm{W}$ \\
\hline Reference Datum & - \\
\hline Projection & - \\
\hline $\mathrm{KB} / \mathrm{RT}(\mathrm{m})$ & 23.47 \\
\hline Water Depth (m) & 499.26 \\
\hline TD (mRT) & 2459.12 \\
\hline Age at TD & Precambrian (Crystalline Basement) \\
\hline Primary Objective & Prognosed Paleocene deltaic sequences \\
\hline Secondary Objective & $\begin{array}{l}\text { Lower Paleocene pro-delta submarine fan } \\
\text { sands. Additional Jurassic and Lower } \\
\text { Cretaceous sands also a target. }\end{array}$ \\
\hline Play/Trap Style & Prograding Paleocene-aged delta sands \\
\hline Reason for Failure & $\begin{array}{l}\text { Invalid Geological target. The prognosed } \\
\text { Paleocene deltaic sequence consisted of } \\
\text { volcanic hyaloclastite delta (as in well } 163 / 6 \\
\text { - la). After encountering a } 324 \text { m thick sub- } \\
\text { lava sequence of conglomerates of unknown } \\
\text { age, the well TD'd in Lewisian basement. }\end{array}$ \\
\hline
\end{tabular}

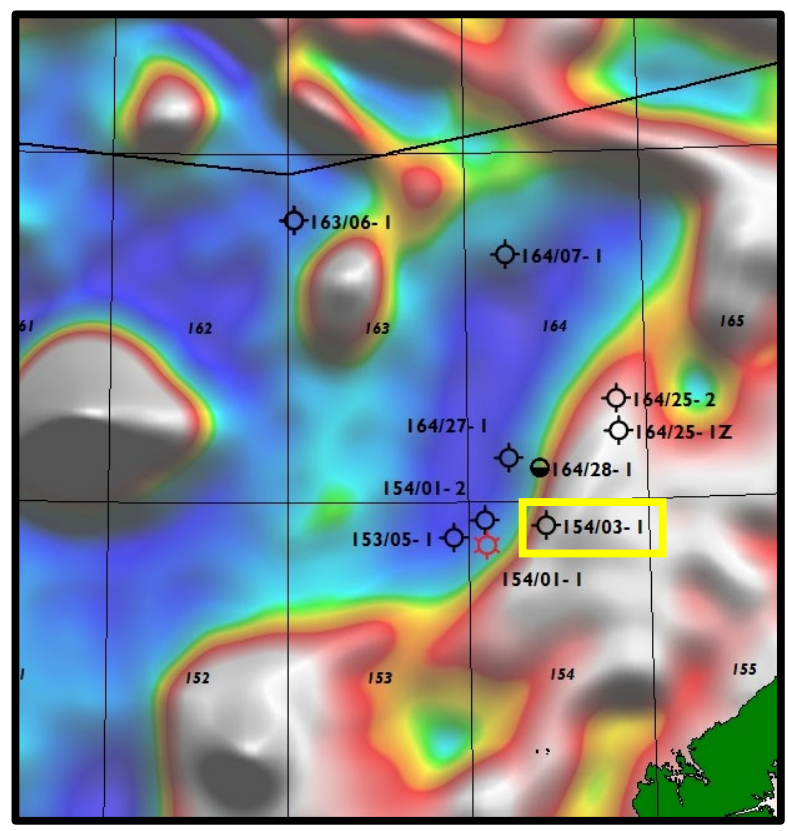




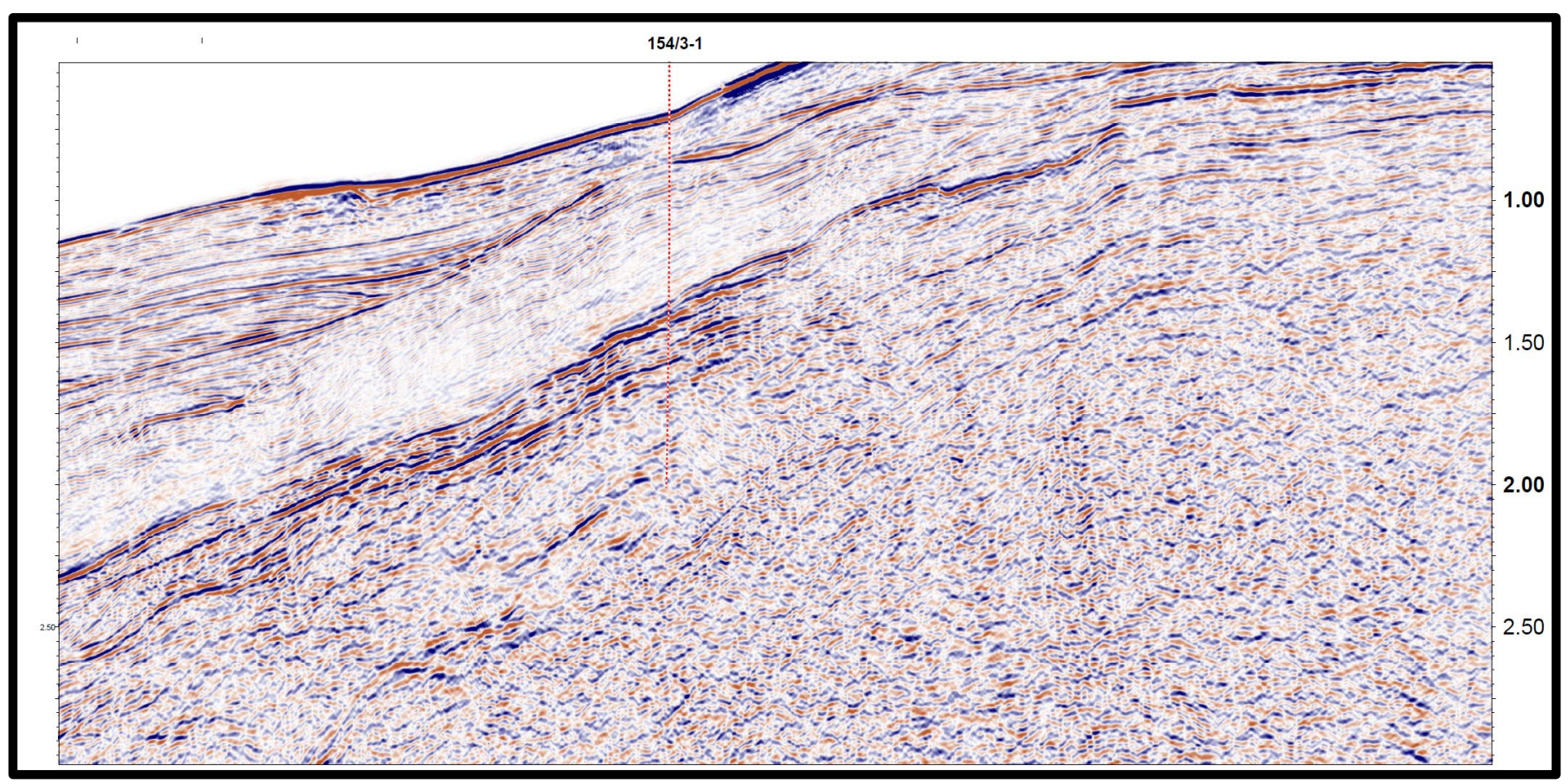

Figure 24 - Seismic line orientated NW-SE across I54/3-I. (Seismic Line CN9I-I09A) 


\section{I54/3-I Stratigraphic Summary}

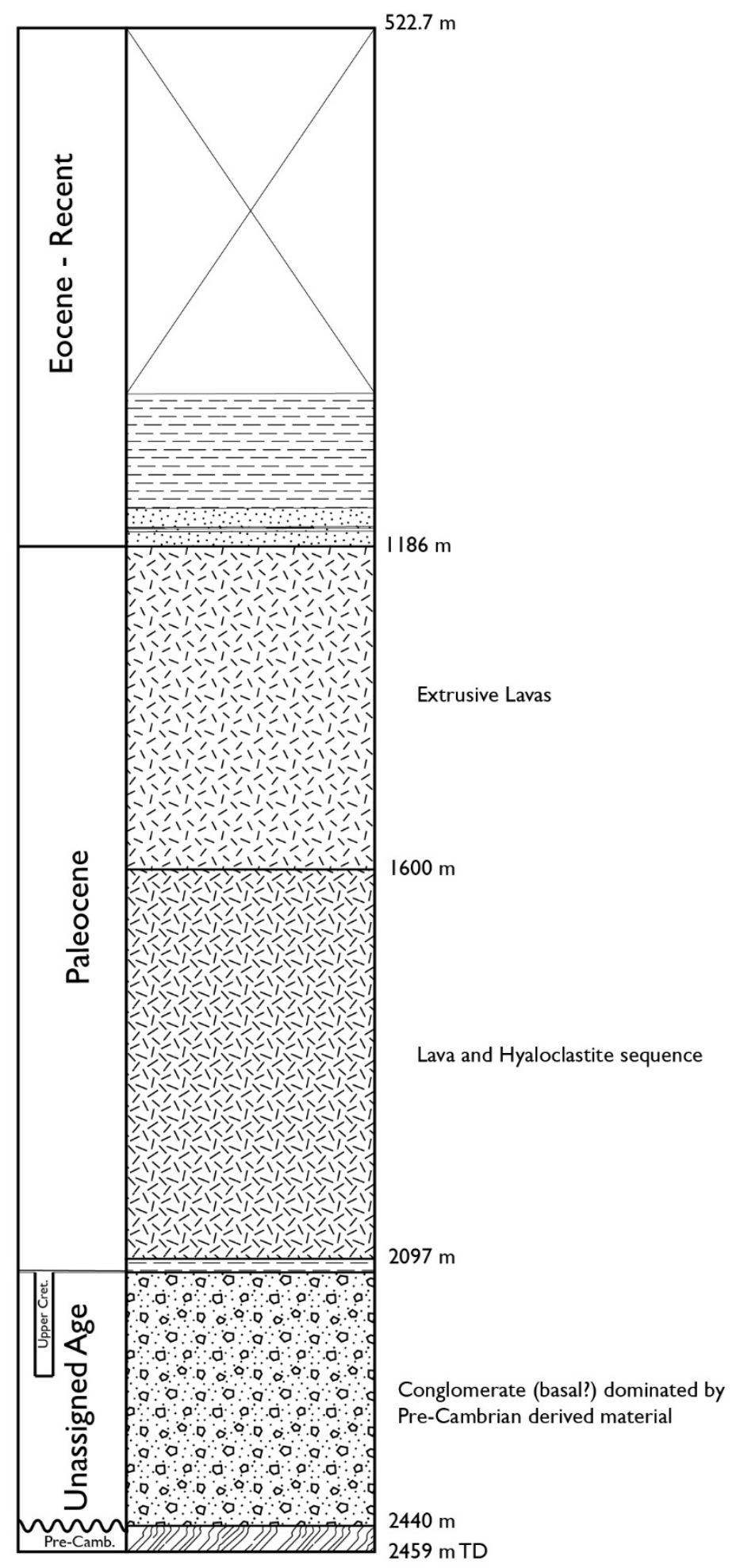

Figure 25 - Stratigraphic summary of well I54/3-I 


\section{Summary}

Well 154/3-I marked the first well drilled in the UK Rockall area by an operator aside from BNOC/BP. The target of the well was prognosed sedimentary delta situated beneath the Paleocene extrusive lava sequences. Unfortunately, on drilling the prognosed pro-delta submarine fan was found to be volcanic in origin (Fig. 24 \& 25). Inspection of both seismic and well data suggests that, as with 163/6-la, the prognosed sedimentary delta, is actually a volcanic hyaloclastite delta, formed by submarine eruption of prograding lava flows. This material is variously referred to, wrongly, as Tuff and Tuffaceous siltstone within the lithological descriptions.

\section{Structure}

None defined specifically in well documents

\section{Shows}

No sign of hydrocarbons found in the well

\section{Reservoir}

A $50 \mathrm{~m}$ argillaceous sandstone was encountered at I I $32 \mathrm{~m} \mathrm{MD}$, directly overlying the volcanic sequence. This sandstone was later identified by Marathon as the shallow marine equivalent of the deep-water Eocene fans targeted by well 153/5-I. No other significant reservoir sequence was encountered

\section{Seal}

Was prognosed to have been Paleocene lavas.

\section{Potential Source Rocks}

No potential source rocks sequences where penetrated by the well.

\section{Comments}

Well 154/3-I was a disappointing first exploration well within the Rockall for Conoco. However, in 1991, the seismic interpretation and understanding of volcanic facies present within a subsurface sedimentary basin context was in an embryonic state. Although the occurrence of volcanic hyaloclastite deltas within volcanic sequences in sedimentary basins is now well documented, in 1991, this was not the case along the Atlantic Margin. This ultimately led to the wrong pre-well prognosis and invalid geological target. 


\section{64/7-I 'The Dome Prospect' (Drilled in 1997)}

\begin{tabular}{|c|c|}
\hline Operator & Conoco \\
\hline Date Spudded & $30 / 08 / 1997$ \\
\hline TD Date & $19 / 12 / 1997$ \\
\hline Days Drilling & II 2 days ( 3 months, 20 days) \\
\hline Type & Exploration Wildcat \\
\hline Status & P\&A - Dry Hole \\
\hline Shows & None \\
\hline License & P.963 \\
\hline Latitude & $59^{\circ} 42^{\prime} 32.184^{\prime \prime} \mathrm{N}$ \\
\hline Longitude & $07^{\circ} 46^{\prime} 06.124^{\prime \prime} \mathrm{W}$ \\
\hline Reference Datum & Not stated \\
\hline Projection & Hayford Ellipsoid \\
\hline $\mathrm{KB}(\mathrm{m})$ & 25.6 \\
\hline Water Depth (m) & 768 \\
\hline TD (mRT) & 5129.2 \\
\hline Age at TD & Cretaceous \\
\hline Primary Objective & $\begin{array}{l}\text { To evaluate a large four-way dip closed } \\
\text { dome-shape structure identified sub-basalt, } \\
\text { and target multiple prognosed targets from } \\
\text { Syn-rift to Pre-rift }\end{array}$ \\
\hline Secondary Objective & $\begin{array}{l}\text { Test for source rock potential within } \\
\text { prognosed intra Syn-rift strata. }\end{array}$ \\
\hline Play/Trap Style & Four-way structural closure \\
\hline Reason for Failure & $\begin{array}{l}\text { Four-way closure was found to be the result } \\
\text { of doming by underlying laccolithic plutonic } \\
\text { body. The target was heavily intruded by } \\
\text { sills, with no reservoir sequences present, } \\
\text { with sub-volcanic section being mudstone } \\
\text { dominated. The well did not exit the Late } \\
\text { Cretaceous strata, due to extreme } \\
\text { overthickening of the sequence caused by } \\
\text { intrusions (see Schofield et al. 20l8) }\end{array}$ \\
\hline
\end{tabular}

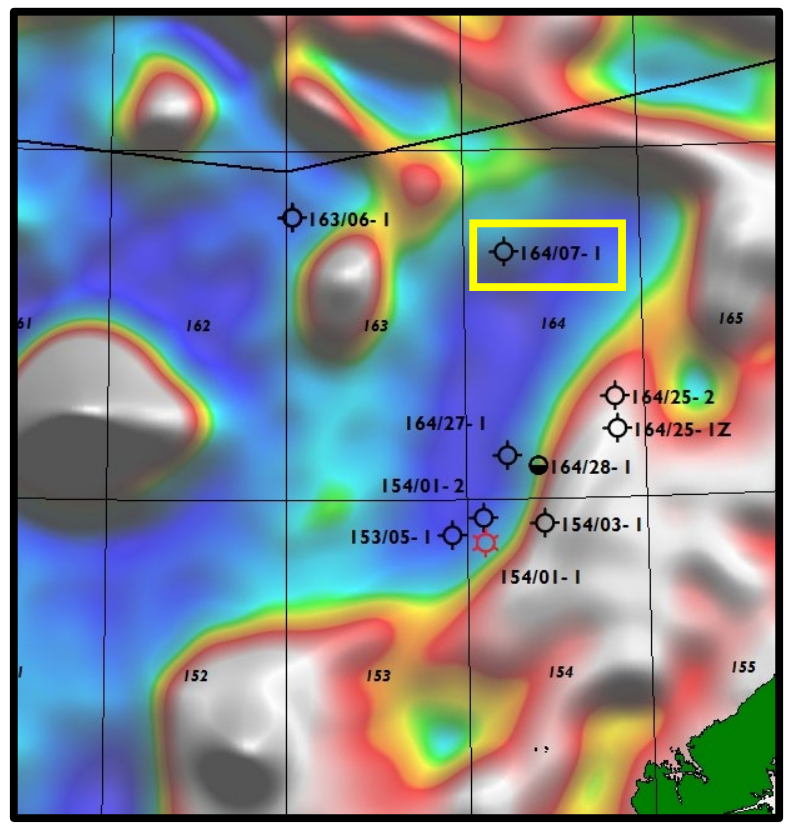




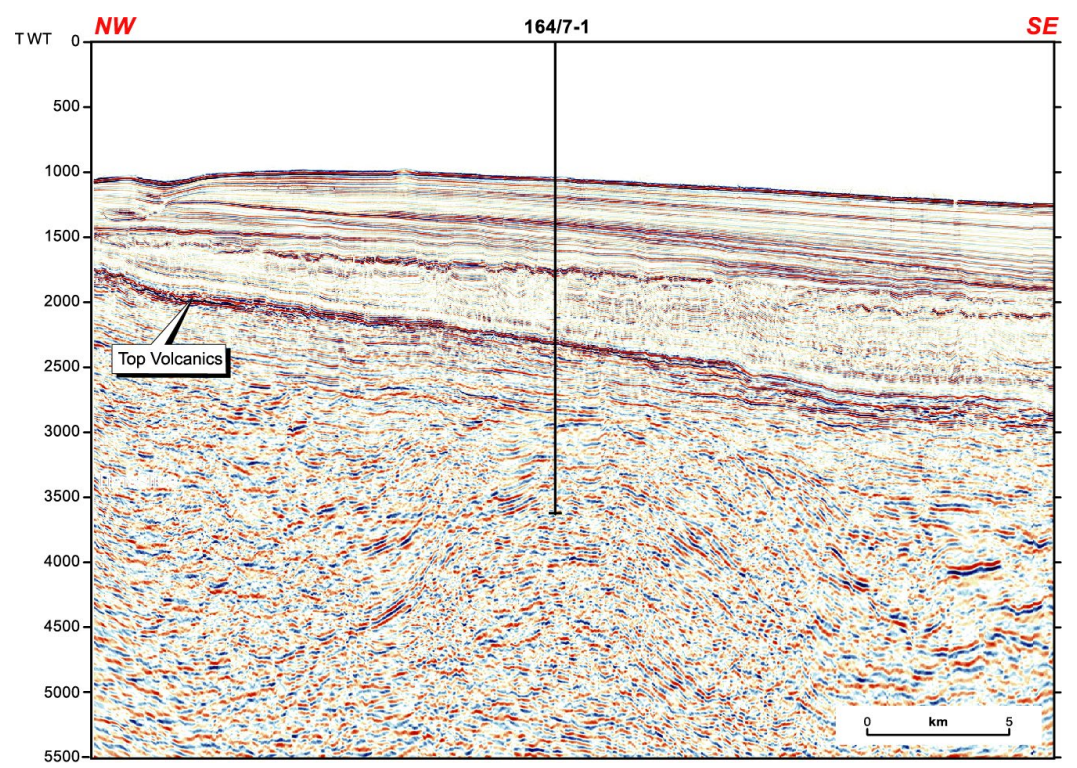

Figure $\mathbf{2 6}$ - From Archer et al. 2005 showing sub-basalt anticlinal structure targeted by the well

$\mid 64 / 7-1$

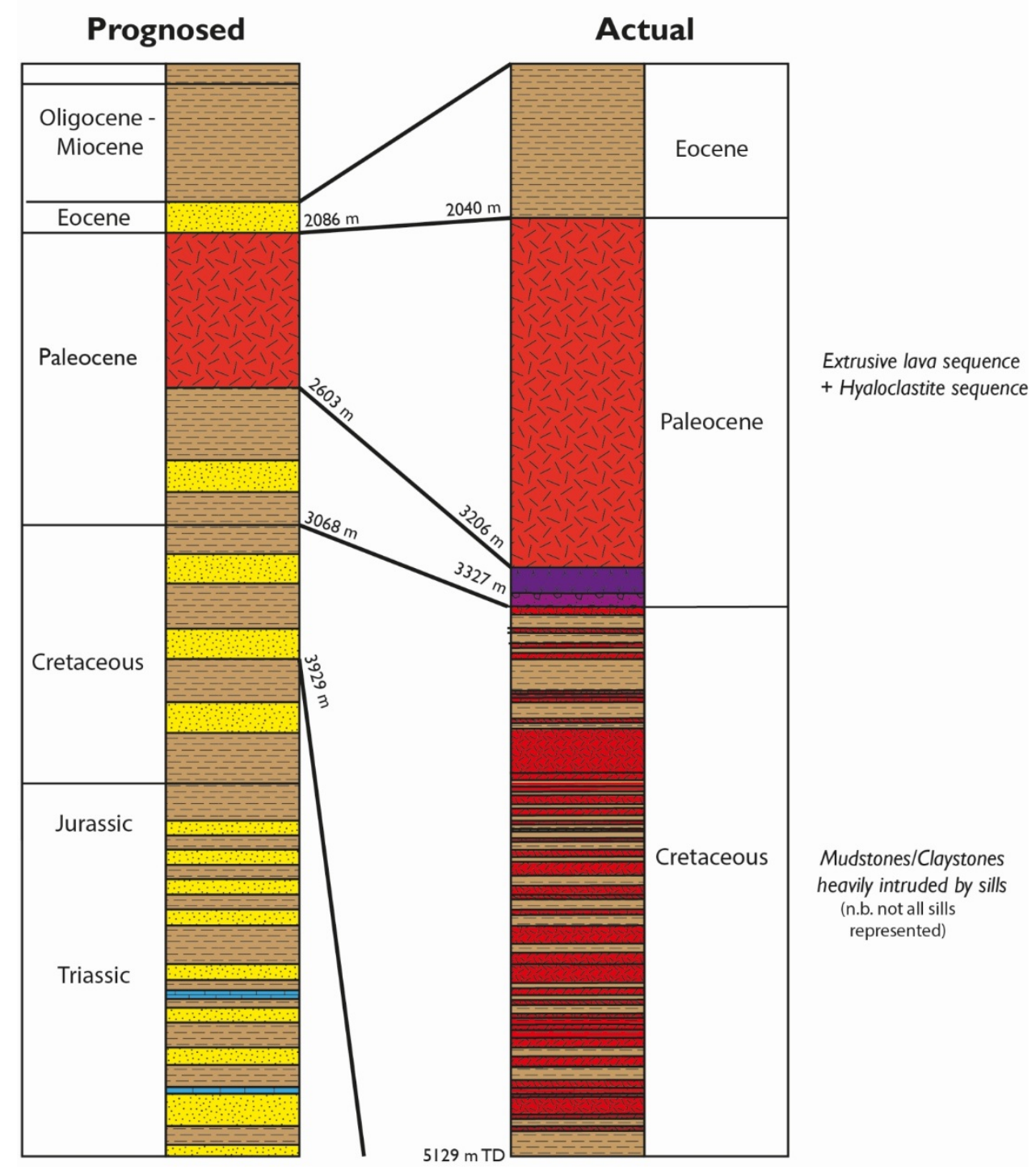

Figure 27 - Prognosed vs Actual for well 164/7-I 


\section{Summary}

The 'Dome' prospect was drilled in 1997, marking the second well drilled by Conoco in the UK Rockall and the 2nd phase of exploration in the UK Rockall after a 6-year hiatus. The geology and results of the well is comprehensively summarised by Archer et al. (2005). The prospect was designed to test a fourway sub-basalt closure that had been identified on regional 2D seismic lines (Fig. 26). The pre-well prognosis was that of a rollover anticline consisting of a series of interbedded shales and sandstones. However, upon drilling it was found that the thickness of the extrusive package was over twice the thickness that had been predicted in the pre-drill interpretation (5 I8 m predicted vs. II65 m actual) (Fig. 27). This discrepancy was largely down to the presence of a thick sequence of relatively low-amplitude hyaloclastites below the sub-aerial lava sequence. In the pre-drill interpretation, this facies change had been wrongly interpreted as the contact between the volcanic and underlying sedimentary sequence. On exit of the $\sim 1.2 \mathrm{~km}$ lava pile, the thick Cretaceous section was found to have been heavily intruded by Paleogene aged sills (approximately $70 \%$ sills to $30 \%$ host rock) (Fig. 27). It was discovered that the subvolcanic seismic reflectivity, which pre-drill had been thought to be the result of interbedded shale and sandstone sequences, was in fact caused by sill-shale contacts. No sand bodies were encountered in the entire $1.8 \mathrm{~km}$ sub-volcanic Cretaceous drilled section.

\section{Structure}

Four-way dip closed sub-basalt target

\section{Shows}

No sign of hydrocarbons found in the well

\section{Reservoir}

No reservoir sequences present. Entire sub-basalt section was composed of mudstone and sill intrusions, with a ratio of approximately $70 \%$ intrusions to $30 \%$ mudstone.

\section{Seal}

None specifically defined in well documents

\section{Potential Source Rocks}

No potential source rock sequences where penetrated by the well. VR data collected from the Cretaceous sub-volcanic section of the well ranged from $2.5 \%$ Ro at top of sub-volcanic section, to $\sim 6.23 \%$ Ro at based the well, illustrating both the heating nature of the sills and underlying plutonic body (Archer et al. 2005)

\section{Comment}

Well 164/7-I represented a high risk-high reward well, and the first major test of sub-basaltic prospectivity on the Atlantic Margin. Ultimately, the well was a failure and illustrates why care must be taken in interpretation of reflectivity in sub-basalt targets. Additionally, the well also demonstrates an extreme case of 'overthickening' of the Cretaceous (see Schofield et al. 2018) by igneous intrusions. 


\section{53/5-I (Drilled in 2000)}

\begin{tabular}{|c|c|}
\hline Operator & Marathon Oil Uk Ltd. \\
\hline Date Spudded & $20 / 04 / 2000$ \\
\hline TD Date & $12 / 05 / 2000$ \\
\hline Days Drilling & 23 days \\
\hline Type & Exploration \\
\hline Status & P\&A Dry Hole \\
\hline Shows & No shows \\
\hline License & P.957 \\
\hline Latitude & $58^{\circ} 53^{\prime} 55.67 \mathrm{~N}$ \\
\hline Longitude & $08^{\circ} 04^{\prime} 43.07 \mathrm{~W}$ \\
\hline Reference Datum & - \\
\hline Projection & - \\
\hline $\mathrm{KB}(\mathrm{m})$ & 25.6 \\
\hline Water Depth (m) & 1248.4 \\
\hline TD (mRT) & 2987 \\
\hline Age at TD & Paleocene \\
\hline Primary Objective & $\begin{array}{l}\text { To investigate the lithofacies and } \\
\text { hydrocarbon potential of the Early Eocene } \\
\text { section. Specifically the deep-water } \\
\text { equivalent of the 'Lower Orkney Group' } \\
\text { sand which the shallow marine equivalent } \\
\text { had been intersected in offset wells (I54/3- } \\
\text { I, } 164 / 25-1 \mathrm{z}, 164 / 25-2)\end{array}$ \\
\hline Secondary Objective & - \\
\hline Play/Trap Style & Stratigraphic pinch-out \\
\hline Reason for Failure & Lack of charge \\
\hline
\end{tabular}

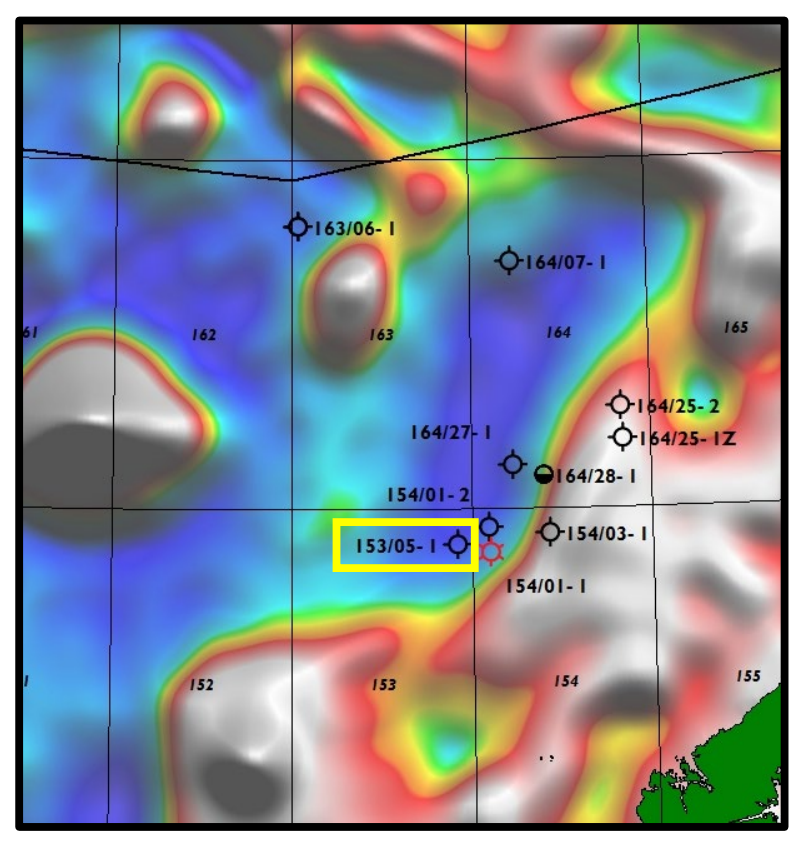




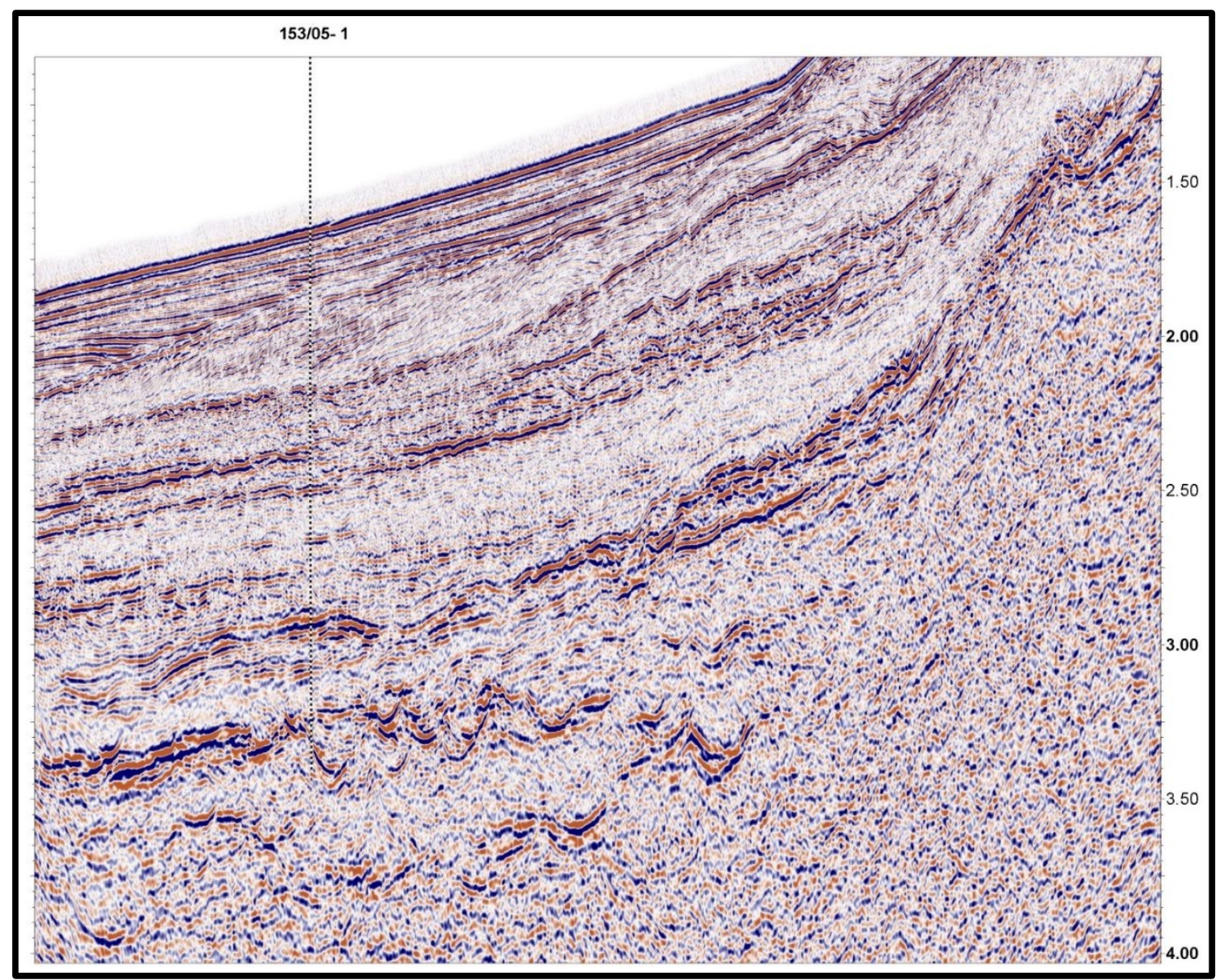

Figure 28 - Seismic line orientated NW-SE through I53/5-I (Seismic Line AM_AUK_88_37) 


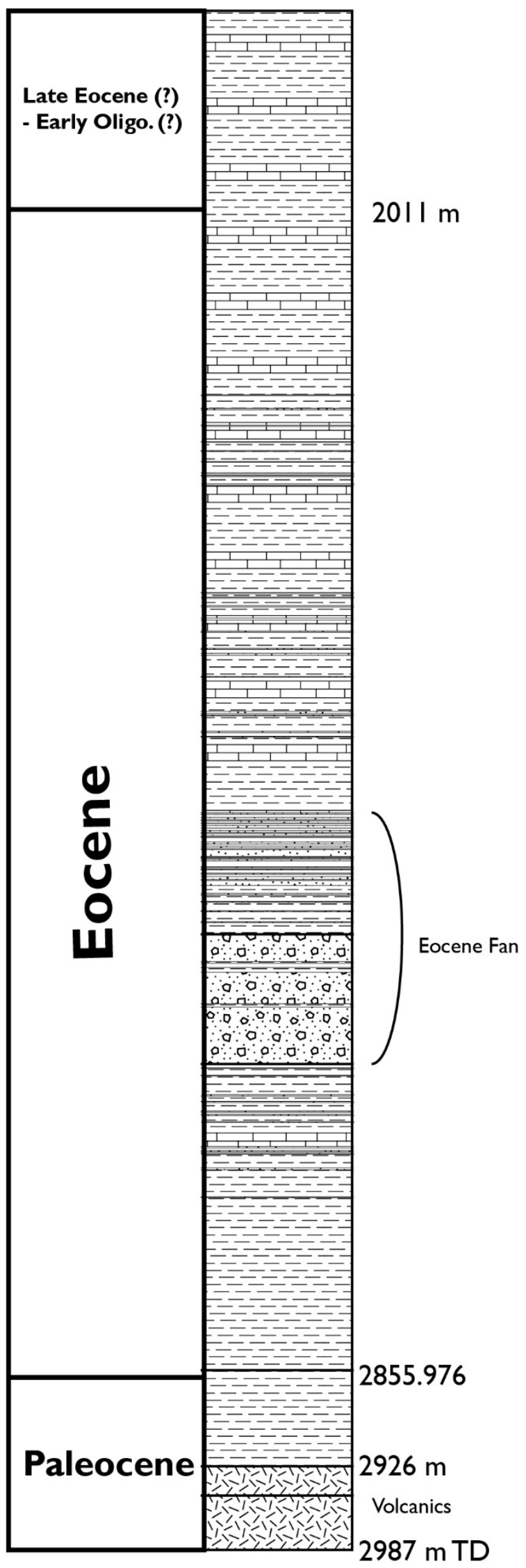

Figure 29 - Stratigraphic summary of well I54/5-I 


\section{Summary}

Well 153/05-I, drilled in 2000, was a commitment well, after Marathon was awarded license P.957 in the $17^{\text {th }}$ Licensing round. The well was designed to investigate the lithofacies and hydrocarbon potential of the Early Eocene submarine fan systems within Rockall (Fig. 28). The well was dry and contained no oil shows (Fig. 29). The submarine fan origin of the reservoir sequences was confirmed and consisted of a stacked succession of coarse clastic lithologies (Fig. 29). Petrographic analysis of cuttings (no core or side-wall cores where taken), demonstrated a variety of sandstone and detrital grain types. Interestingly, the framework mineralogies for each sandstone type were dominated by unstable, immature assembles abundant in K-feldspar and basaltic lithics. Visible porosity of the recovered sandstone cuttings was apparently poor, in contradiction of the log-derived porosities that show an average porosity of $26 \%$.

\section{Structure}

The well was drilled on a prognosed up-dip stratigraphic pinch-out of the Eocene-aged submarine fan.

\section{Shows}

No hydrocarbon shows encountered

\section{Reservoir}

The reservoir consisted of a total gross section of $94 \mathrm{~m}$ of coarse clastic sediments.

\section{Seal}

The seal consisted of overlying Eocene claystone and limestone sequence.

\section{Potential Source Rocks}

No source rocks horizons where penetrated in well.

\section{Comments}

Well 153/5-I represented an important test of the Eocene fans of Rockall. Log-derived porosity through the Eocene fan was on average $26 \%$, however petrographic analysis of the cuttings did raise a potential issue of reservoir quality due to low visible porosity and large quantities of basaltic lithic clasts. As KFeldspar (noted in the petrographic analysis) is usually a minor component in basaltic sequences, the likely source for the K-Feldspar is the Lewisian Gneiss of the Outer Hebrides. 


\section{I54/I-I - Benbecula South (Drilled in 2000)}

\begin{tabular}{|l|l|}
\hline Operator & Enterprise \\
\hline Date Spudded & $5 / 04 / 2000$ \\
\hline TD Date & $10 / 05 / 2000$ \\
\hline Days Drilling & 36 days (I month, 6 days) \\
\hline Type & Exploration Wildcat \\
\hline Status & $\begin{array}{l}\text { P\&A - Gas Discovery (54 m column, GWC } \\
\text { at } 2907 \text { m) }\end{array}$ \\
\hline Shows & No liquid hydrocarbon shows \\
\hline License & P.958 \\
\hline Latitude & $58^{\circ} 52^{\prime} 30.492^{\prime \prime}$ N \\
\hline Longitude & $07^{\circ} 53^{\prime} 58.435^{\prime \prime}$ \\
\hline Reference Datum & ED50 \\
\hline Projection & International Spheroid \\
\hline KB (m) & 29 \\
\hline Water Depth (m) & 1017.4 \\
\hline TD (mRT) & 3050 \\
\hline Age at TD & Upper Cretaceous \\
\hline Primary Objective & Prognosed Paleocene turbidite sandstones \\
\hline Secondary Objective & N/A \\
\hline Play/Trap Style & Four-way closure \\
\hline
\end{tabular}

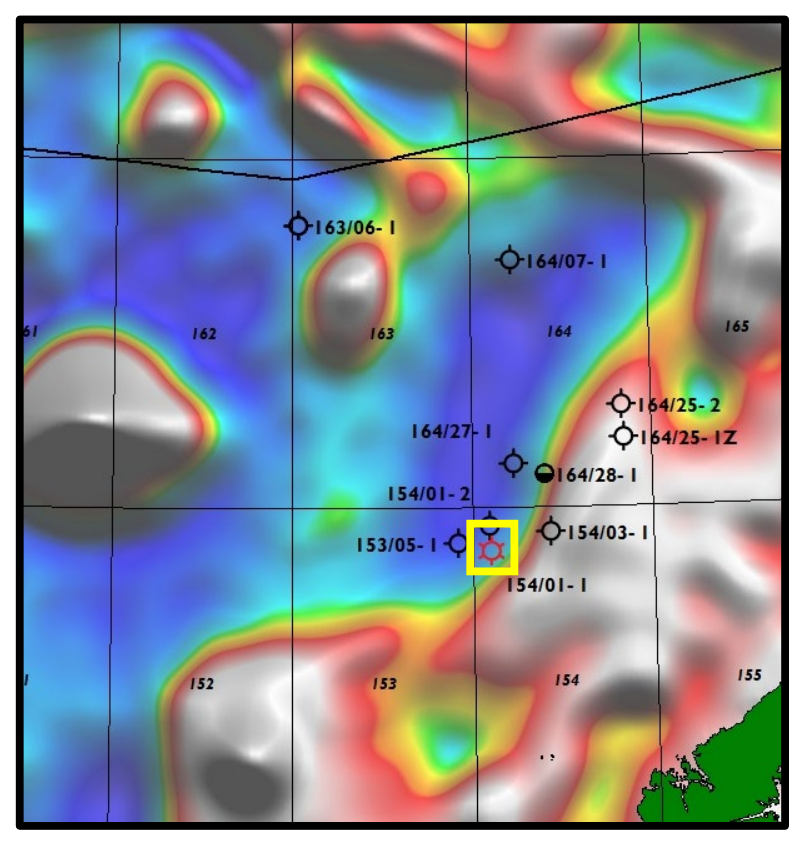


Figure 30 - Figure showing location of I54/I - I discovery within the NE Rockall Basin

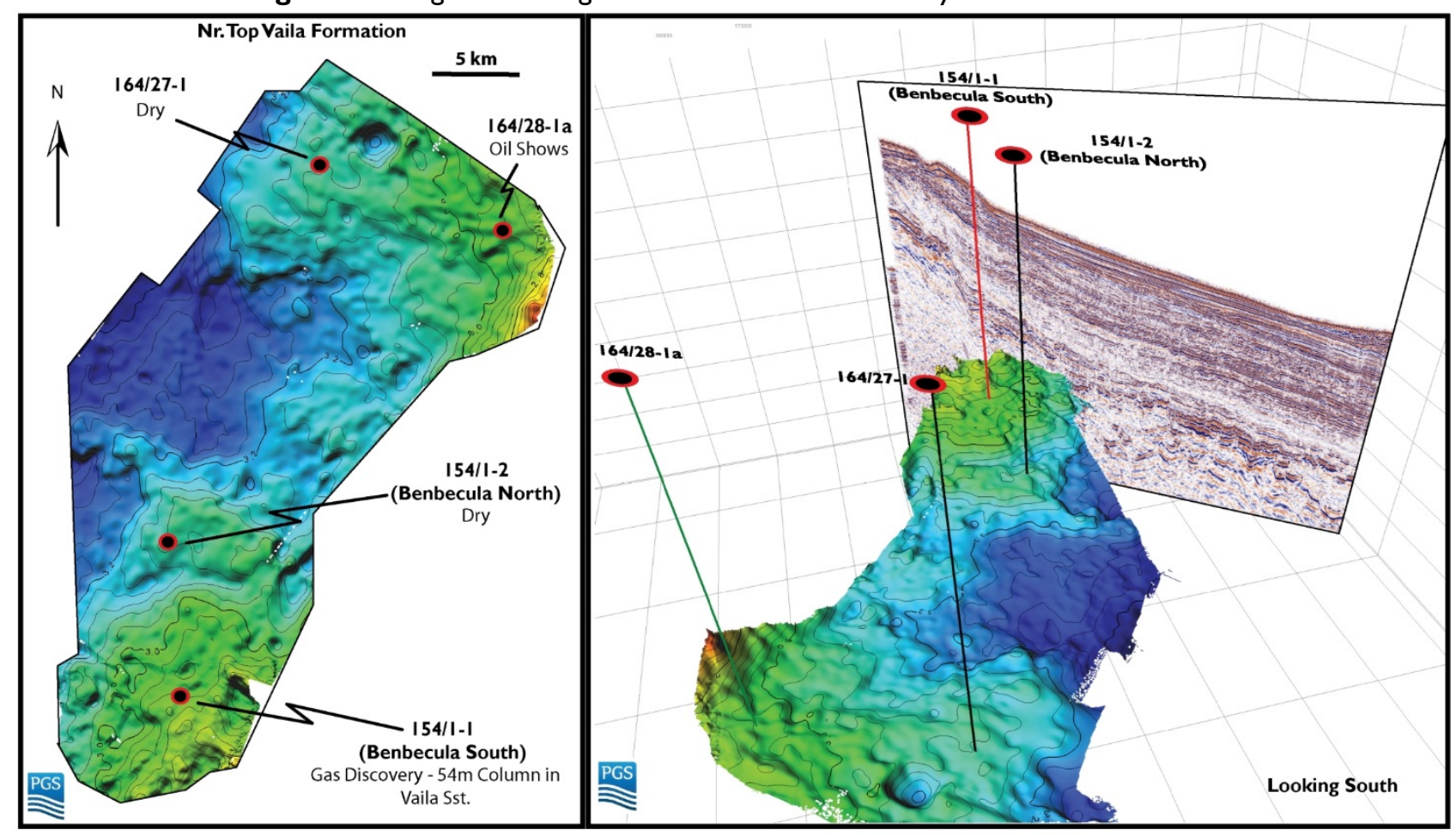

Figure 3 I - TWT map showing nr. Top Vaila Fm. and Benbecula closure (from Schofield et al. 20 I8)

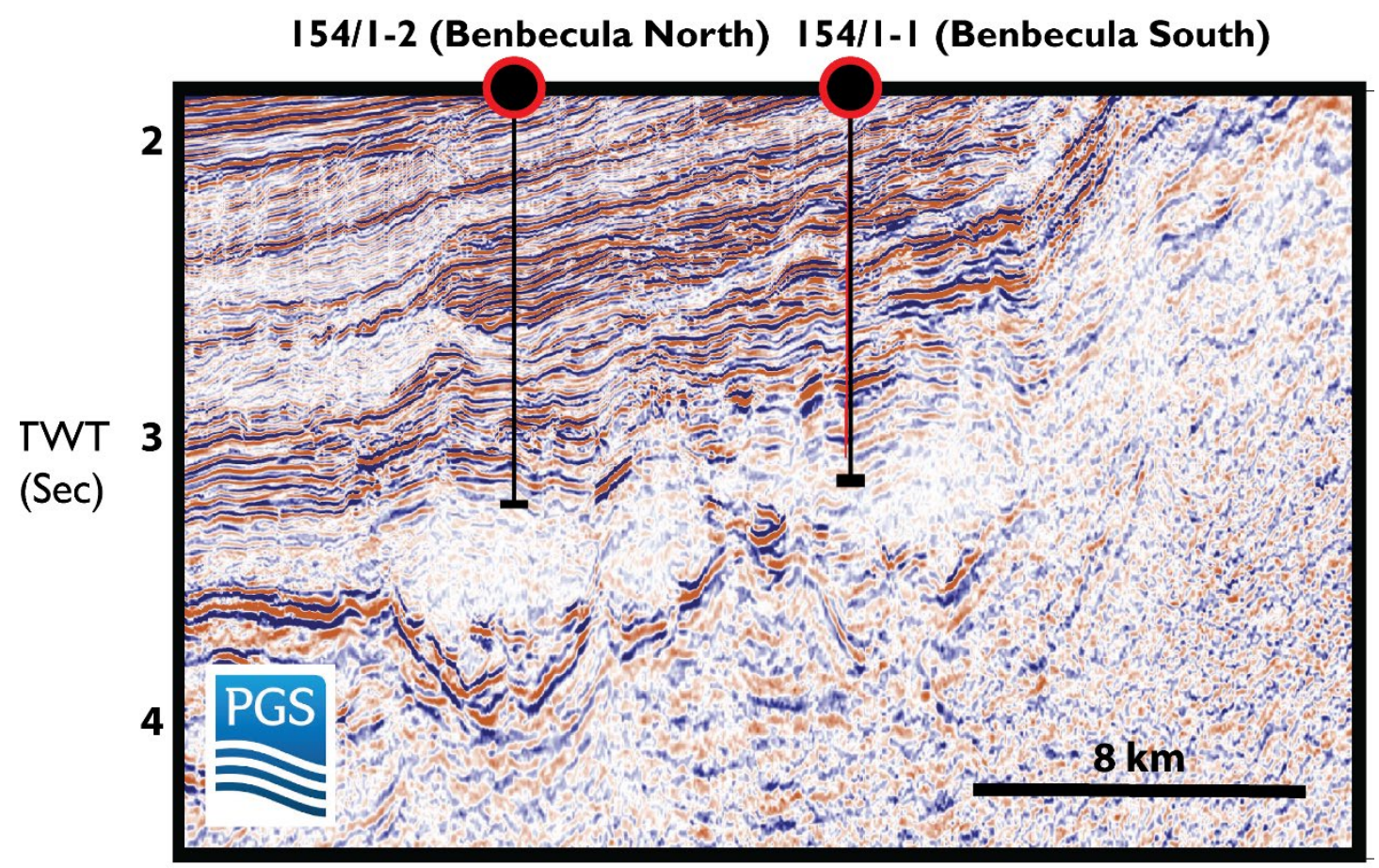

Figure 32 - From Schofield et al. (20I8) showing Benbecula South (I54/I-I) and Benbecula North (I54/I-2) 

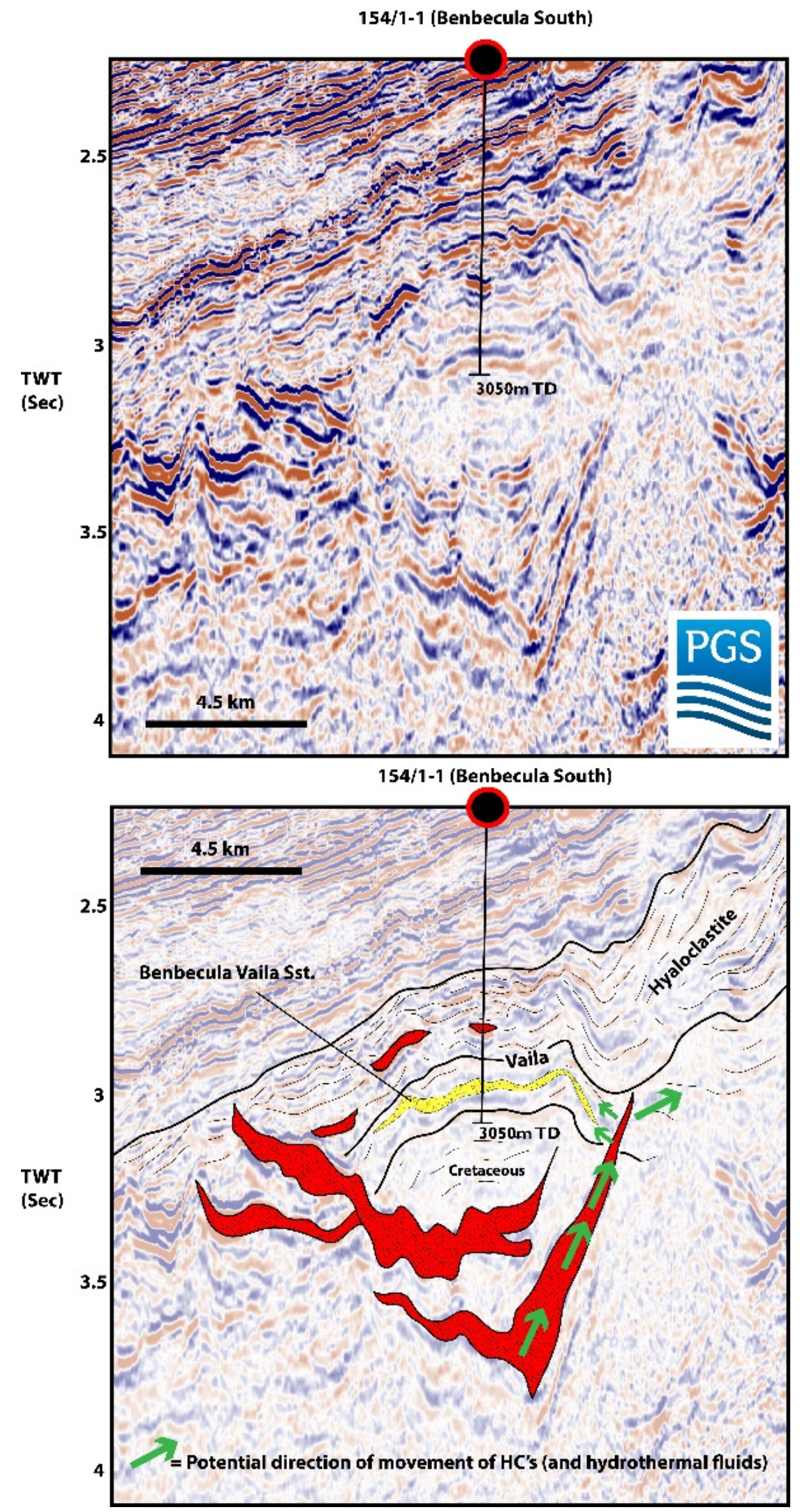

Figure 33 - Seismic and Geoseismic interpretation through Benbecula South (I54/I-I) discovery (From Schofield et al. 2018) 


\section{|54/I-I}

Prognosed

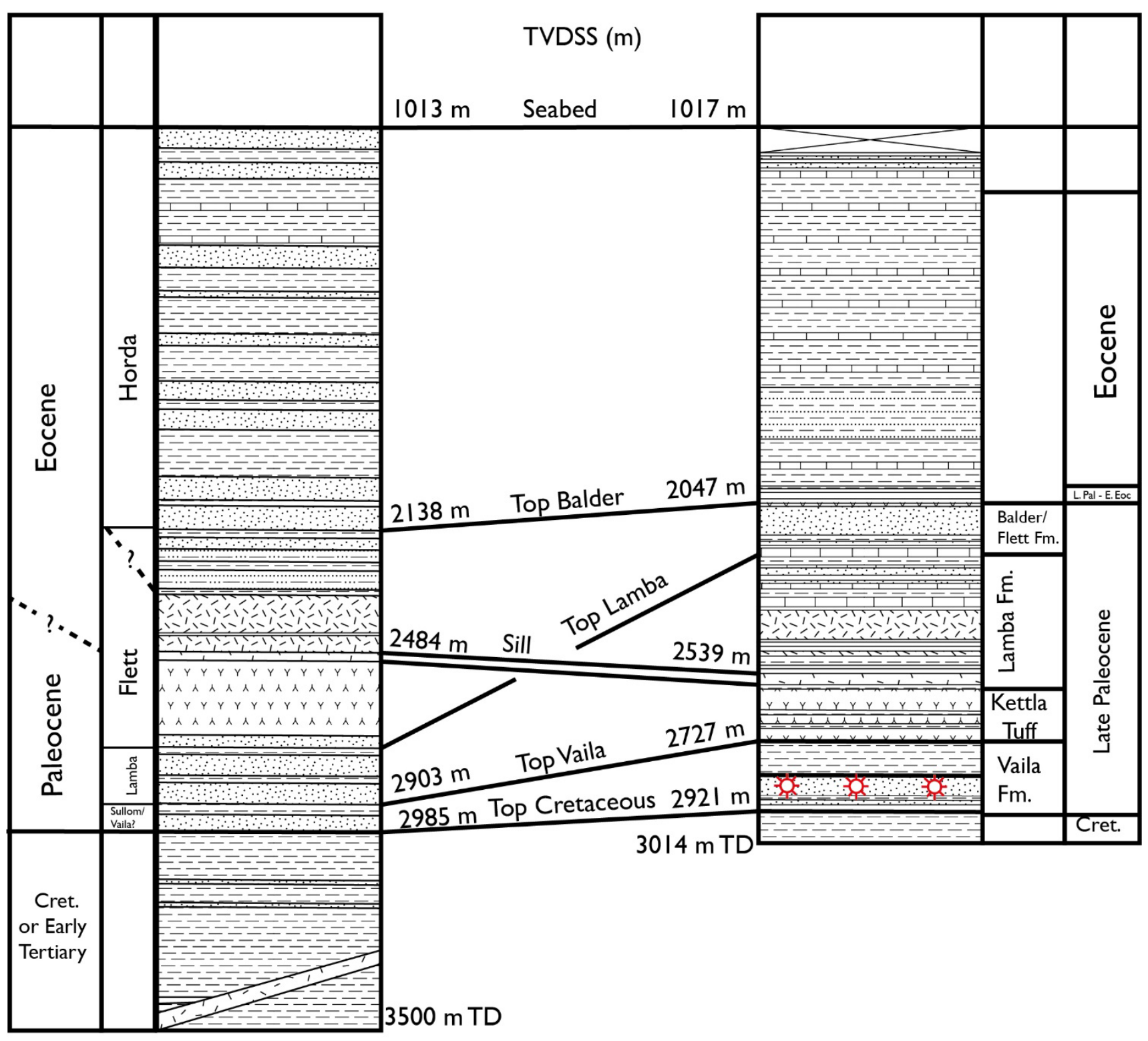

Figure 34 - Prognosed vs. Actual for well I54/I-I 


\section{Summary}

Benbecula South (I54/I-I) was drilled during April and May of 2000 by Enterprise Oil, and the primary objective of the well was to establish hydrocarbons in Palaeocene sands in a four-way dip closure (Fig. 3I,32 \& 33). The well encountered a 54 metre gas column within Vaila Fm. equivalent sandstones (Fig. 34), though no traces of liquid hydrocarbons were found. The seal comprised of shale and an overlying hyaloclastite unit. The fact that Benbecula intersected a gas column proves that Rockall does possess a source rock capable of generating hydrocarbons, even if its extent and maturity remain enigmatic.

\section{Structure}

Four-way closure

\section{Shows}

Gas Discovery (54 m column, GWC at 2907 m)

\section{Reservoir}

Sequence T22-T36 Vaila Fm. equivalent turbidites

\section{Seal}

Thought to comprise of overlying shale and hyaloclastite

\section{Potential Source Rocks}

No potential source rocks were penetrated by the well. Isotopic analysis found the Benbecula South gas possesses a 'very unusual isotopic signature'. The favoured explanation being that the gas is a mixture of a small amount of normally generated "oil associated" gas the result of normal burial, plus a more extensive amount of dry methane caused by extensive "oil to gas" cracking, potentially caused by igneous intrusions. This would imply that a source rock interval does/did exists within the NE Rockall which generated volumes of gas, but that a second charge of gas was also created by cracking by heating from igneous intrusions, potentially as a result of intrusion into source rock regions.

\section{Comments}

Well I54/I - I provides the only discovery in the UK Rockall as of 2018, and due to its presence beneath $\sim 120 \mathrm{~m}$ of basaltic hyaloclastite sequences actually represents a sub-basalt discovery on the UKCS. Due to underlying sill intrusions, imaging of the source rocks which potentially charged Benbecula still remains highly challenging. 


\section{64/28- I A (Drilled in 2000)}

\begin{tabular}{|l|l|}
\hline Operator & ENI/AGIP UK \\
\hline Date Spudded & $24 / 05 / 2000$ \\
\hline TD Date & $06 / 07 / 2000$ \\
\hline Days Drilling & 44 days (I month, I3 days) \\
\hline Type & Exploration \\
\hline Status & P\&A - Oil Shows \\
\hline Shows & $\begin{array}{l}\text { Multiple Oil Shows within Vaila Fm. No } \\
\text { associated gas }\end{array}$ \\
\hline License & P.960 \\
\hline Latitude & $59^{\circ} 05^{\prime} 37.036^{\prime \prime} N$ \\
\hline Longitude & $07^{\circ} 35^{\prime} 5$ I.046’W \\
\hline Reference Datum & ED50 \\
\hline Projection & - \\
\hline KB (m) & 29 \\
\hline Water Depth (m) & 85 I \\
\hline TD (mRT) & 3328.5 \\
\hline Age at TD & Upper Cretaceous \\
\hline Primary Objective & $\begin{array}{l}\text { Assess the presence of hydrocarbon } \\
\text { accumulations in three vertically stacked } \\
\text { targets in basinal setting of NE Rockall. }\end{array}$ \\
\hline Secondary Objective & - \\
\hline Play/Trap Style & Four-way closure \\
\hline Reason for Failure & $\begin{array}{l}\text { Lack of trap at Vaila Sst. Level - Migration up- } \\
\text { dip away from well location? }\end{array}$ \\
\hline
\end{tabular}

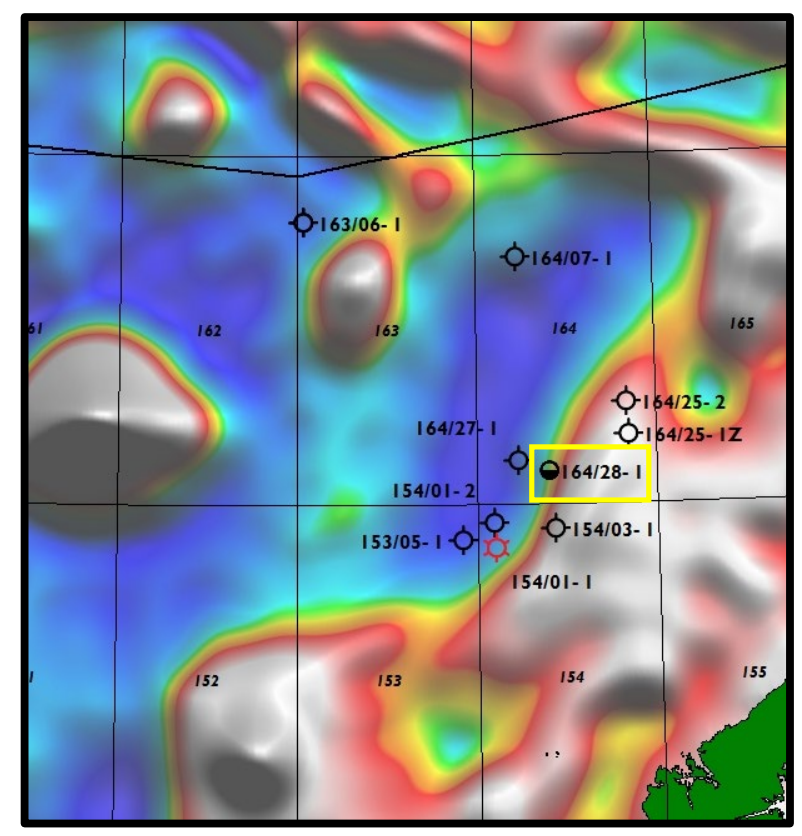




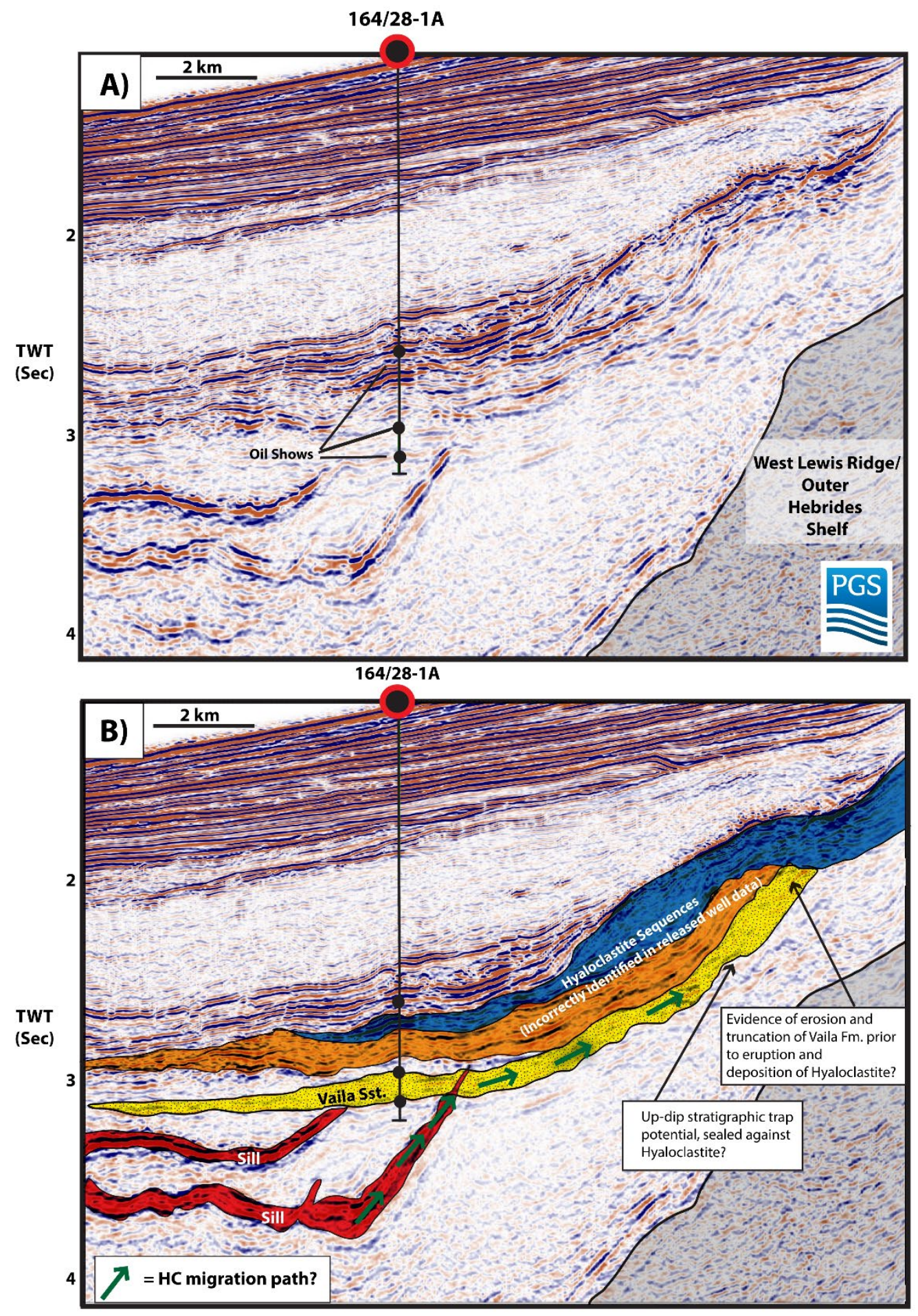

Figure 35 - From Schofield et al. (2018). a, b) Seismic and geoseismic interpretation through well 164/28-IA, which encountered oil shows within the Flett and Vaila Formation sequences. 


\section{| 64/28- I A}

Prognosed

\section{Actual}

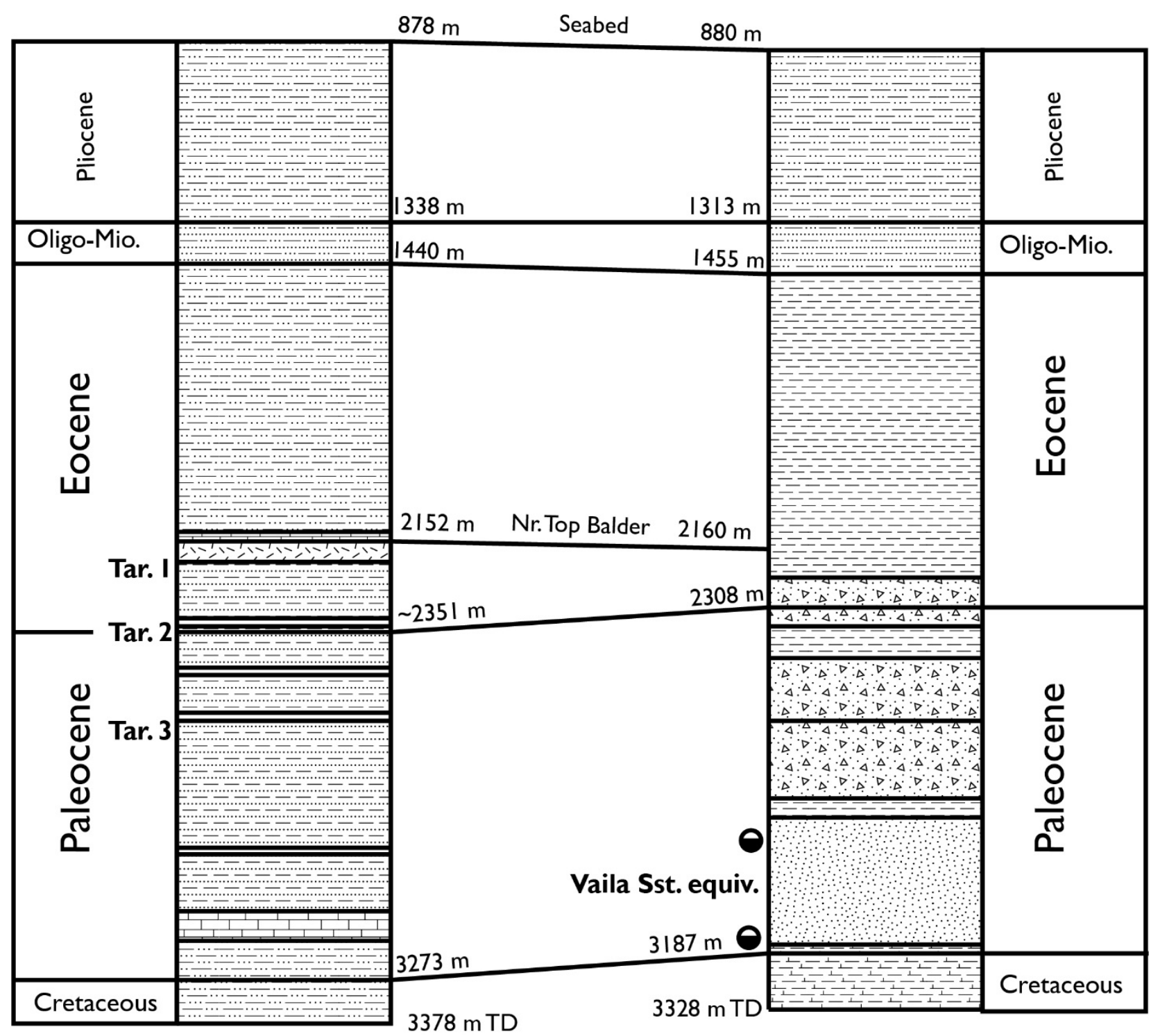

Figure 36 - Prognosed vs Actual of well I64/28-IA 


\section{Summary}

Well 164/28-IA was drilled from May to July of 2000 by ENI, coeval with Enterprise's Benbecula (I54/I I) well. The well had three separate targets in a broad four-way dip closure, although in the deeper Vaila Fm. section, the closure is less well defined (Fig. 35). Upon drilling, the well was found to have oil shows within the Vaila Fm. sequences, but with no associated gas (Fig. 36).

\section{Structure}

Four-way dip closure

\section{Shows}

Multiple oil shows, mainly within the Vaila sandstone. One strongly biodegraded hydrocarbon show was recorded in cuttings at $2300 \mathrm{~m}$ within Flett Fm.

\section{Reservoir}

A thick ( $300 \mathrm{~m})$ Sequence T22-T36 Vaila Fm. equivalent reservoir with a very high net:gross.

\section{Seal}

None defined

\section{Potential Source Rocks}

The rock intersected no source rock regions. However, well I64/28-IA is the only well within the UK Rockall to contain traces, in the form of staining, of liquid hydrocarbons. Geochemical analysis, particularly in the lower section of the well $(2864-3169 \mathrm{~m})$, indicates the presence of a relatively anoxic marine source of the oil with significant terrestrial input. The results are noted as being similar to Upper Jurassic marine source rocks in the North Sea (Draupne/Kimmeridge Clay Fm.). This analysis is also currently the only potential indication that Upper Jurassic source rocks may be present at depth and have/had generative oil potential within the UK Rockall. Interestingly, unresolved 'humps' in GC analysis from samples at 2864 $\mathrm{m}$ and $3169 \mathrm{~m}$ (within Vaila sequence) indicate a residual character, possibly as a result of washing or alteration of the liquid hydrocarbons by gas. 


\section{I32/6-I (Drilled in 200 I)}

\begin{tabular}{|c|c|}
\hline Operator & Conoco \\
\hline Date Spudded & $3 / 05 / 2001$ \\
\hline TD Date & $29 / 05 / 200 I$ \\
\hline Days Drilling & 27 days \\
\hline Type & Exploration Wildcat \\
\hline Status & P\&A - Dry Hole \\
\hline Shows & No shows \\
\hline License & P.953 \\
\hline Latitude & $56^{\circ} 45^{\prime} 46.216^{\prime \prime} \mathrm{N}$ \\
\hline Longitude & $09^{\circ} 50 ’ 37.113$ '” \\
\hline Reference Datum & - \\
\hline Projection & - \\
\hline $\mathrm{KB} / \mathrm{RT}(\mathrm{m})$ & 35.96 \\
\hline Water Depth (m) & 1886.407 \\
\hline TD (mRT) & 4369.9176 \\
\hline Age at TD & Late Cretaceous \\
\hline Primary Objective & $\begin{array}{l}\text { Determine presence of reservoirs sands in } \\
\text { Frigg I Formation, Flett Formation and at } \\
\text { Intra-Cretaceous level }\end{array}$ \\
\hline Secondary Objective & - \\
\hline Play/Trap Style & Four-way closure \\
\hline Reason for Failure & $\begin{array}{l}\text { Prognosed as absence of reservoir, issues } \\
\text { may have also occurred with hydrocarbon } \\
\text { migration. }\end{array}$ \\
\hline
\end{tabular}

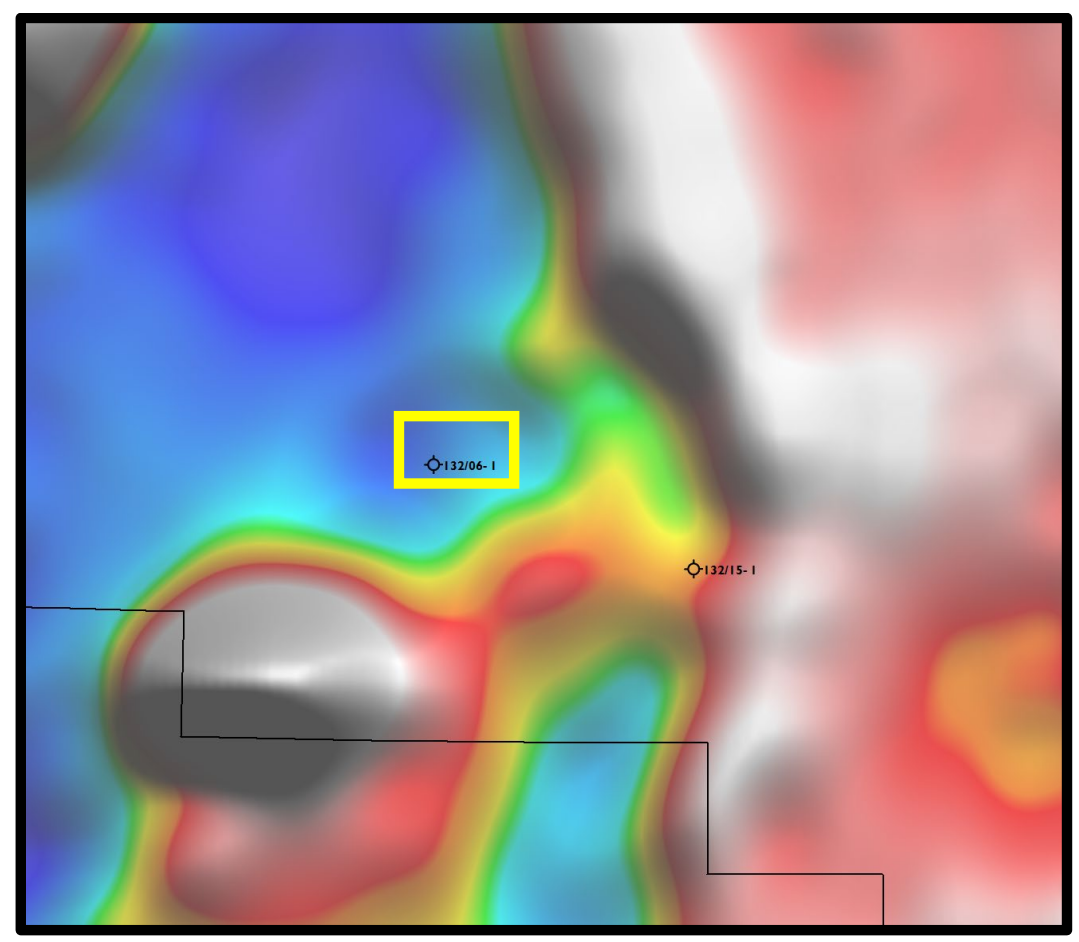




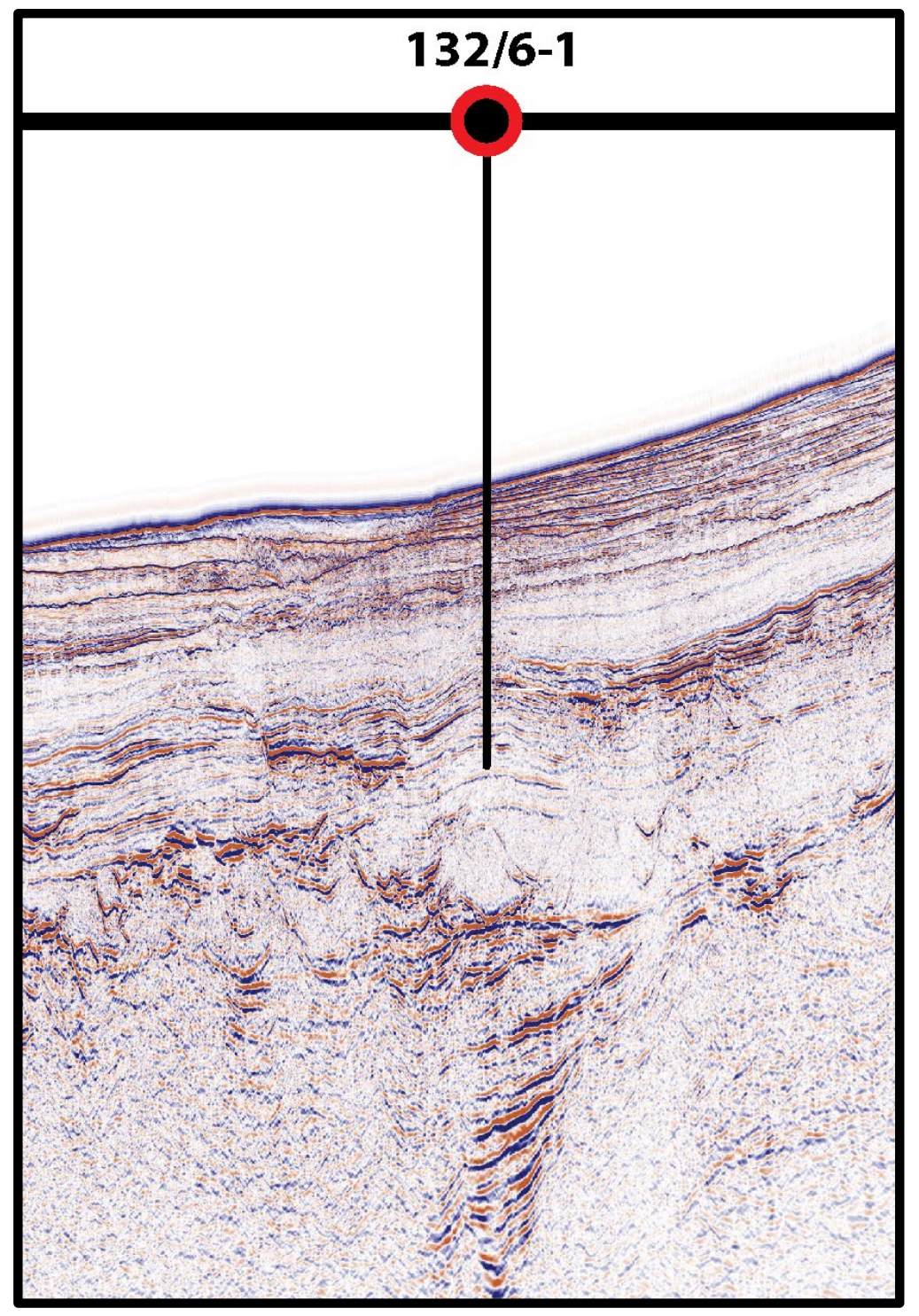

Figure 37 - Seismic line showing well I32/6-I (From Schofield et al. 2018) 


\section{|32/6-|}

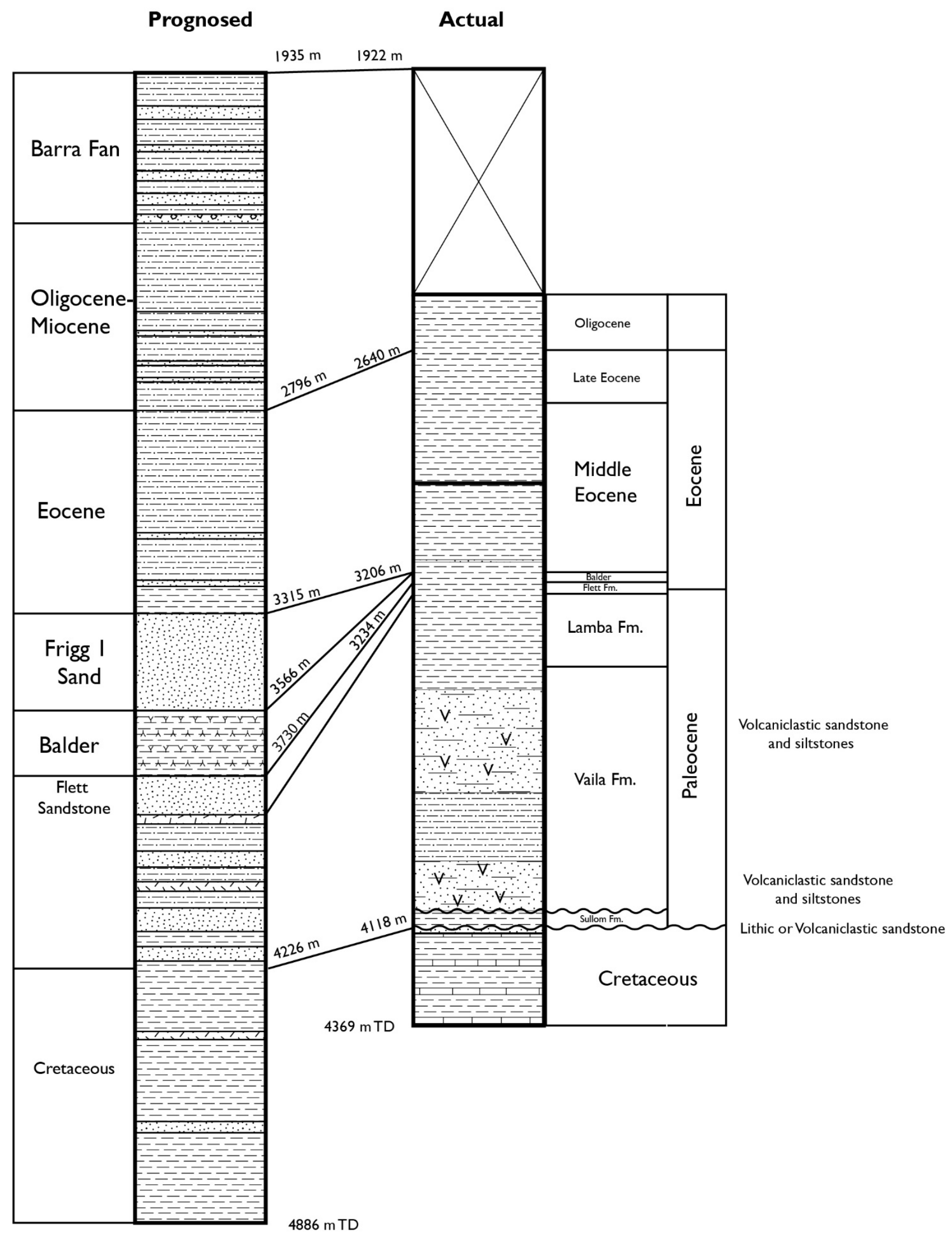

Figure 38 - Prognosed vs Actual for well I32/6-I. Note the two volcaniclastic Vaila Fm. dominated sequences, likely sourced from the nearby Hebridean Terrace volcanic centre 


\section{Summary}

Well 132/06-I, drilled in 200I, represented a commitment well by Conoco after the purchase of Saga Petroleum UK Ltd in 2000. The well was designed to test a large four-way dip closure (Fig. 37). Three main reservoirs were prognosed to be tested, the Horda Frigg I sandstone, Flett Fm. Sandstones and potential intra-Cretaceous sand body. On drilling, the Early Eocene and Paleocene sections were found to be condensed, and were dominated by argillaceous and volcaniclastics lithologies respectively (Fig. 38).

\section{Structure}

Four-way dip closure

\section{Shows}

None

\section{Reservoir}

Although being claystone dominated, several thin sand bodies were encountered

\section{Seal}

Thought to be overlying mudstones of Eocene and Oligo-Miocene age

\section{Potential Source Rocks}

No source rock horizons were penetrated by the well

\section{Comments}

Well I32/6-I concluded a disappointing exploration campaign for Conoco in the UK Rockall and exit from the Basin after 10 years of exploration and three dry exploration wells. The well highlighted the occurrence of thick volcaniclastic sequences within the Vaila, interpreted to be the result of material shed from the Hebridean Terrace and, potentially Anton Dohrn Igneous Centres. This aspect illustrates the substantial risk to Vaila fm. equivalent reservoir sequences within this area. 


\section{4/27-I 'Antaeus' (Drilled in 2002)}

\begin{tabular}{|l|l|}
\hline Operator & Eni UK \\
\hline Date Spudded & $\mathrm{II} / \mathrm{II} / 2002$ \\
\hline TD Date & $9 / \mathrm{I} / 2002$ \\
\hline Days Drilling & 29 days \\
\hline Type & Exploration \\
\hline Status & P\&A - Dry Hole \\
\hline Shows & None \\
\hline License & P.960 \\
\hline Latitude & $59^{\circ} 07^{\prime} 34.657^{\prime \prime} \mathrm{N}$ \\
\hline Longitude & $07^{\circ} 45^{\prime} 54.358^{\prime \prime} \mathrm{W}$ \\
\hline Reference Datum & ED50 \\
\hline Projection & - \\
\hline KB/RT (m) & 29 \\
\hline Water Depth (m) & $\mathrm{II} 73$ \\
\hline TD (mRT) & 2920 \\
\hline Age at TD & Upper Cretaceous \\
\hline Primary Objective & Paleocene Vaila Sandstones \\
\hline Secondary Objective & $\begin{array}{l}\text { Late Paleocene and Early Eocene } \\
\text { (Balder/Flett Fm.) sandstones } \\
\text { conglomerates }\end{array}$ \\
\hline Play/Trap Style & Four-way closure \\
\hline Reason for Failure & $\begin{array}{l}\text { Vaila sandstones encountered as prognosed, } \\
\text { but found to be water wet. Issues with } \\
\text { charge and potential migration routes, see } \\
\text { below. }\end{array}$ \\
\hline & \\
\hline
\end{tabular}

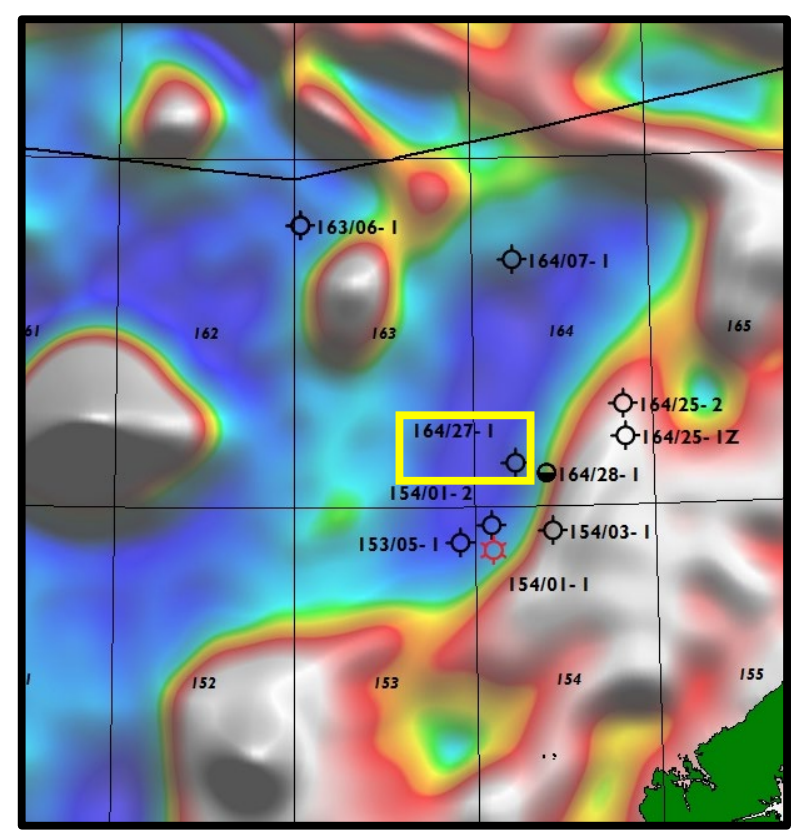




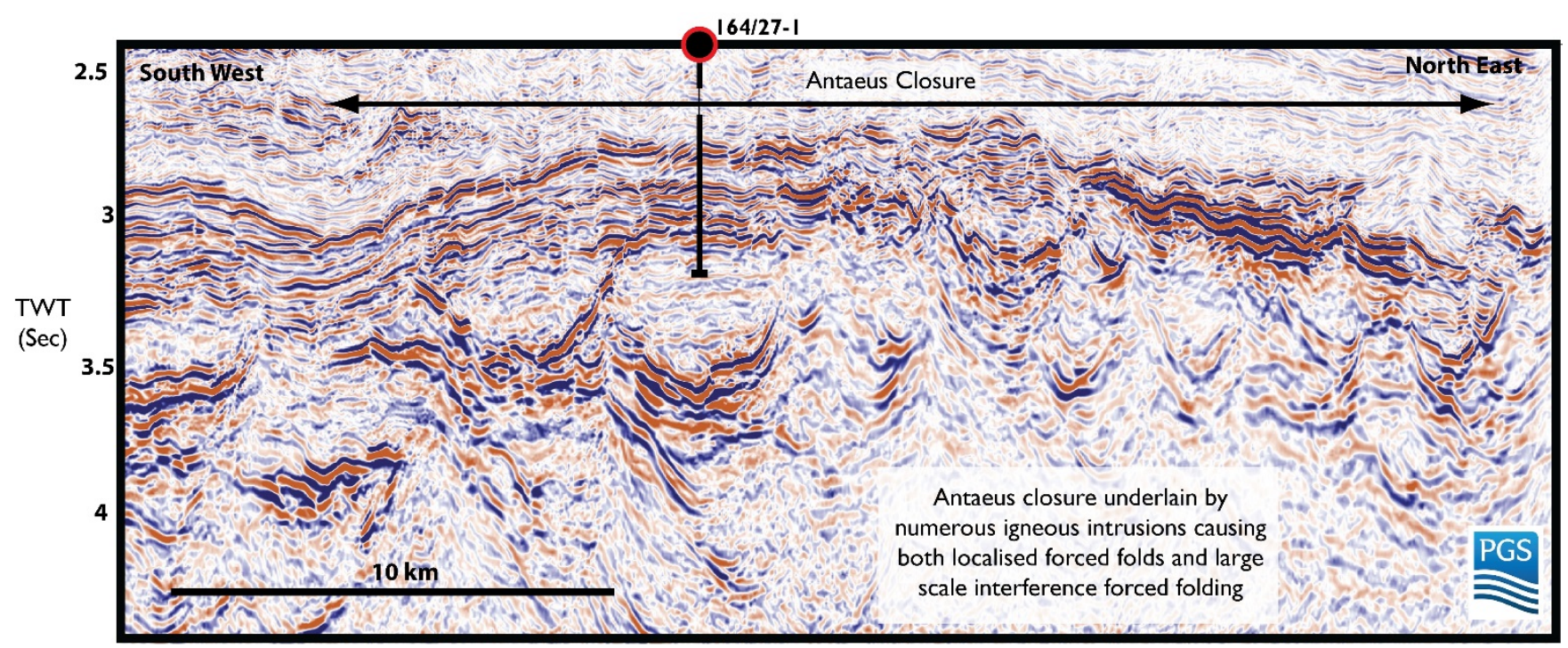

Figure 39 - From Schofield et al. (2018) showing the Antaeus closure targeted by well 164/27-I, note the highly pervasive underlying sill complex underlying the closure

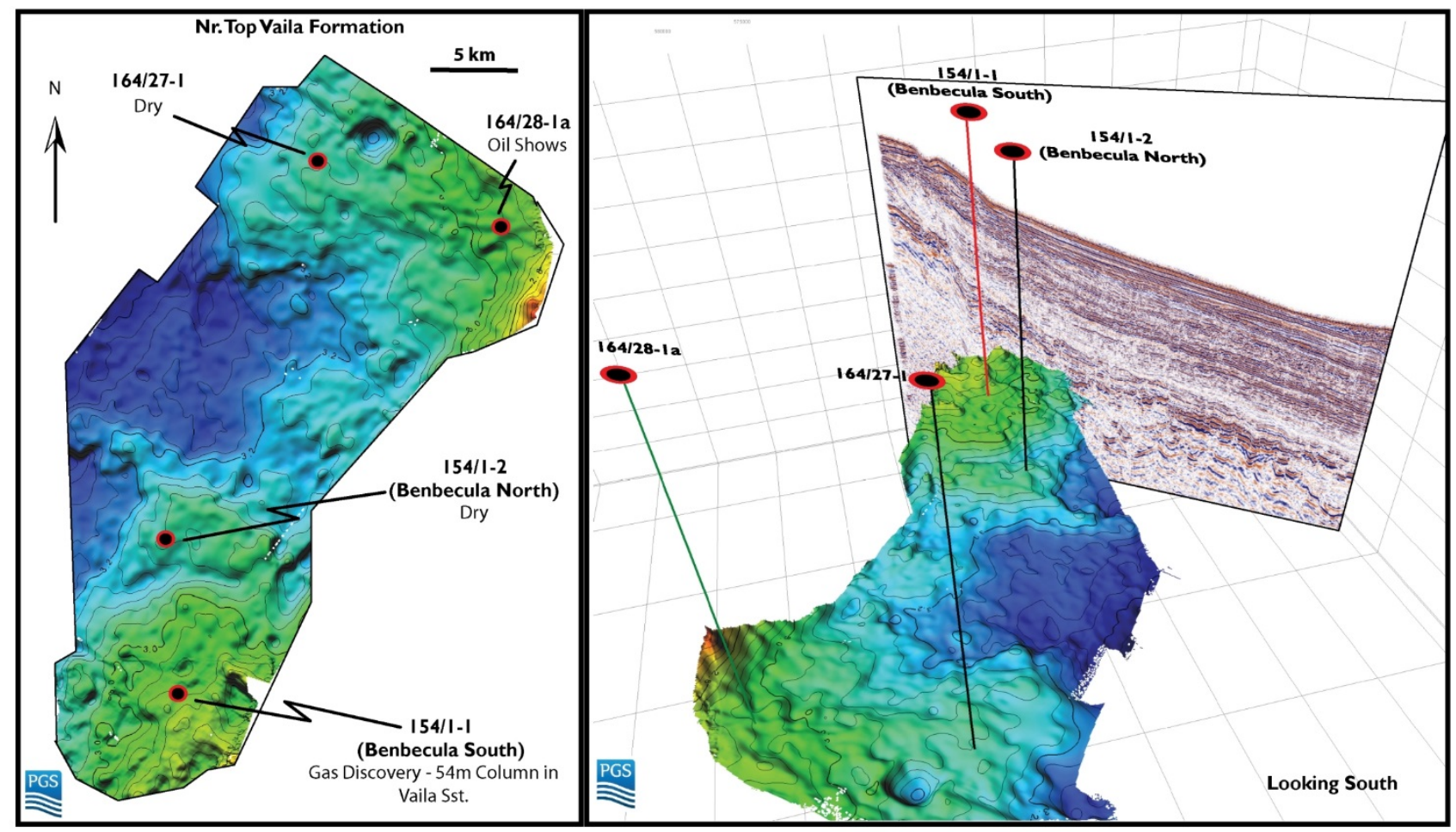

Figure 40 - TWT map of nr. Top Vaila formation showing the location of I64/27-I. (From Schofield et al. 20I8) 


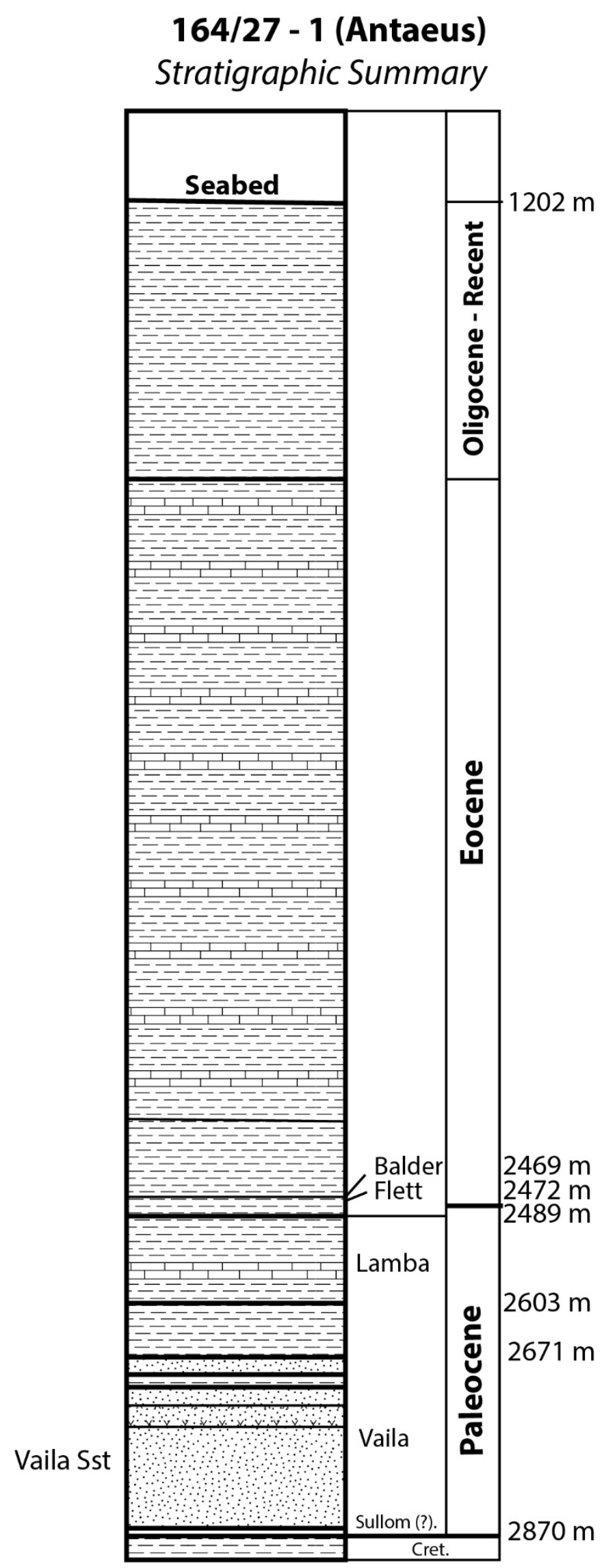

Figure 4 I - Stratigraphic summary of well I64/27-I 


\section{Summary}

Well 164/27-I was drilled during winter conditions in 2002, to test the Antaeus prospect, a well-defined four-way dip closure, situated down dip from I64/28-IA (Fig. 39 \& 40)

The Antaeus prospect consisted of a prognosed wedge of Vaila Fm. sands thought to have been shed into the basin from the Outer Hebrides platform. Upon drilling, the pre-well prognosis of the stratigraphy was largely correct, but the Vaila Fm. sand package was found to contain no hydrocarbons.

Due to poor weather conditions associated with drilling during the beginning of winter, the well lost a total of $\sim 43$ days waiting on weather, related to the need to wait for suitable sea conditions for anchor handling. On reaching TD in early December, approximately 21 days of waiting for suitable conditions was needed before the rig could be demobilised from the well site. However, the well does highlight that winter or late season drilling is still possible in the harsh and unsheltered metaocean conditions of Rockall, albeit with logistical challenges.

\section{Structure}

Four-way dip closure

\section{Shows}

None recorded. However, later fluid inclusion studies showed evidence of oil inclusions below $2735 \mathrm{~m}$ hosted in calcite cement and healed fractures in detrital quartz grains.

\section{Reservoir}

A $218 \mathrm{~m}$ thick Vaila Fm. equivalent friable sandstone was intersected in the well, with minor claystone and Tuff. The reservoir sequence contained no hydrocarbons.

\section{Seal}

Overlying Lamba claystone

\section{Potential Source Rocks}

No source rocks horizons were penetrated by the well

\section{Comments}

Well I64/27-I was located $10 \mathrm{~km}$ to the north-west of well I64/28-Ia. As with well I64/28-Ia, well 164/27-I also intersected a thick (> $200 \mathrm{~m}$ ) Vaila Fm. sst package with very high net:gross. This suggests that a substantial good quality Vaila Fm. equivalent sand fairway exists within this region. Although no hydrocarbon shows were reported, the presence of hydrocarbons in fluid inclusion analysis (see above) would suggest the potential transit of hydrocarbons through this interval, and presence of a source rock. 


\section{54/0 I-2 ‘Benbecula North’ (Drilled in 2006)}

\begin{tabular}{|c|c|}
\hline Operator & Shell \\
\hline Date Spudded & $19 / 06 / 2006$ \\
\hline TD Date & $04 / 08 / 2006$ \\
\hline Days Drilling & 46 days (I month, 16 days) \\
\hline Type & Exploration/Appraisal \\
\hline Status & P\&A - Dry Hole \\
\hline Shows & None \\
\hline License & P.958 \\
\hline Latitude & $58^{\circ} 56^{\prime} 56.362^{\prime \prime} \mathrm{N}$ \\
\hline Longitude & $07^{\circ} 54^{\prime} 30.742^{\prime \prime} \mathrm{W}$ \\
\hline Reference Datum & ED50 \\
\hline Projection & - \\
\hline $\mathrm{KB} / \mathrm{RT}(\mathrm{m})$ & 25 \\
\hline Water Depth (m) & 1212.9 \\
\hline TD (mRT) & 2997.0 \\
\hline Age at TD & Upper Cretaceous \\
\hline Primary Objective & $\begin{array}{l}\text { The objective of the well was threefold } \\
\text { I. To determine presence of } \\
\text { hydrocarbons in the Vaila sandstone } \\
\text { of the North Benbecula structure } \\
\text { 2. Determine economic viability of the } \\
\text { Benbecula South gas discovery } \\
\text { 3. Determine the producibility of the } \\
\text { Vaila sandstone reservoir }\end{array}$ \\
\hline Secondary Objective & - \\
\hline Play/Trap Style & $\begin{array}{l}\text { Northern culmination of the four-way dip } \\
\text { closes structure that provided trap to } \\
\text { Benbecula south }\end{array}$ \\
\hline Reason for Failure & $\begin{array}{l}\text { Vaila sandstone sequence was water-wet. } \\
\text { Potential issues with charge and migration } \\
\text { routes. }\end{array}$ \\
\hline
\end{tabular}

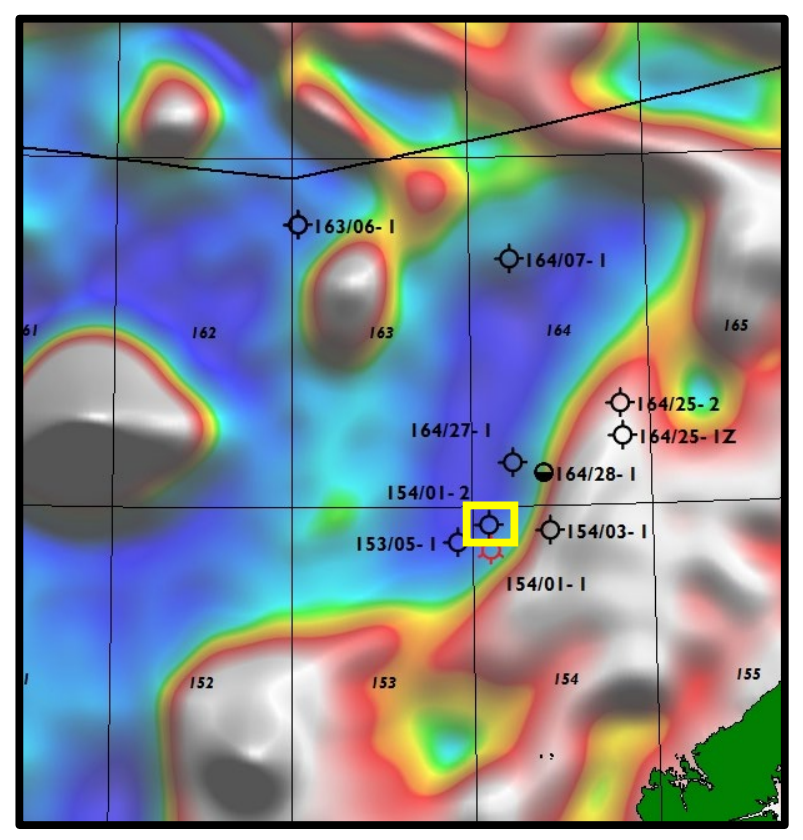




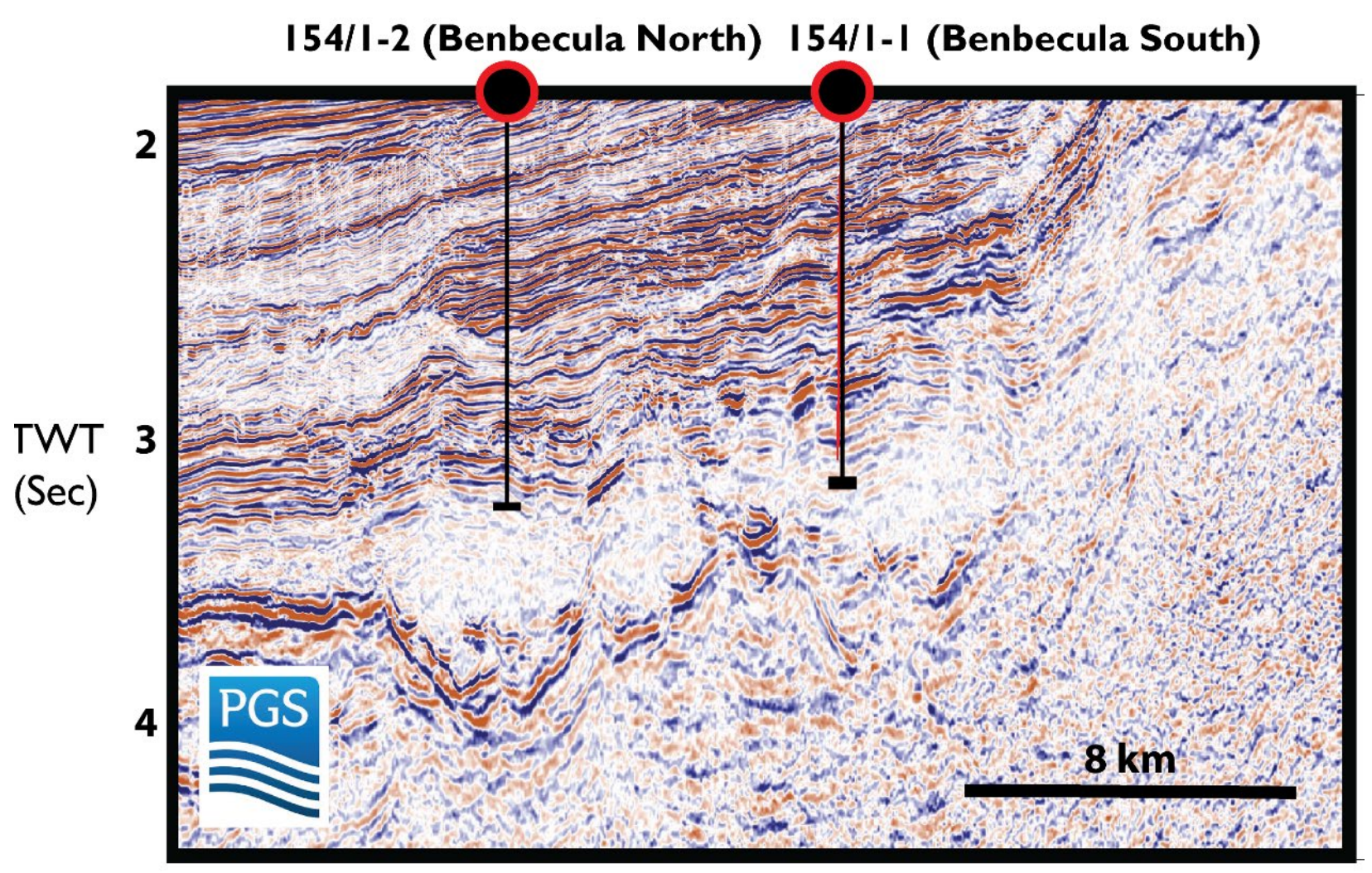

Figure 42 - From Schofield et al. (2018) showing Benbecula North and Benbecula South. Note the underlying saucer-shaped sills beneath the closures 


\section{I54/I-2 Benbecula North}

Stratigraphic Summary

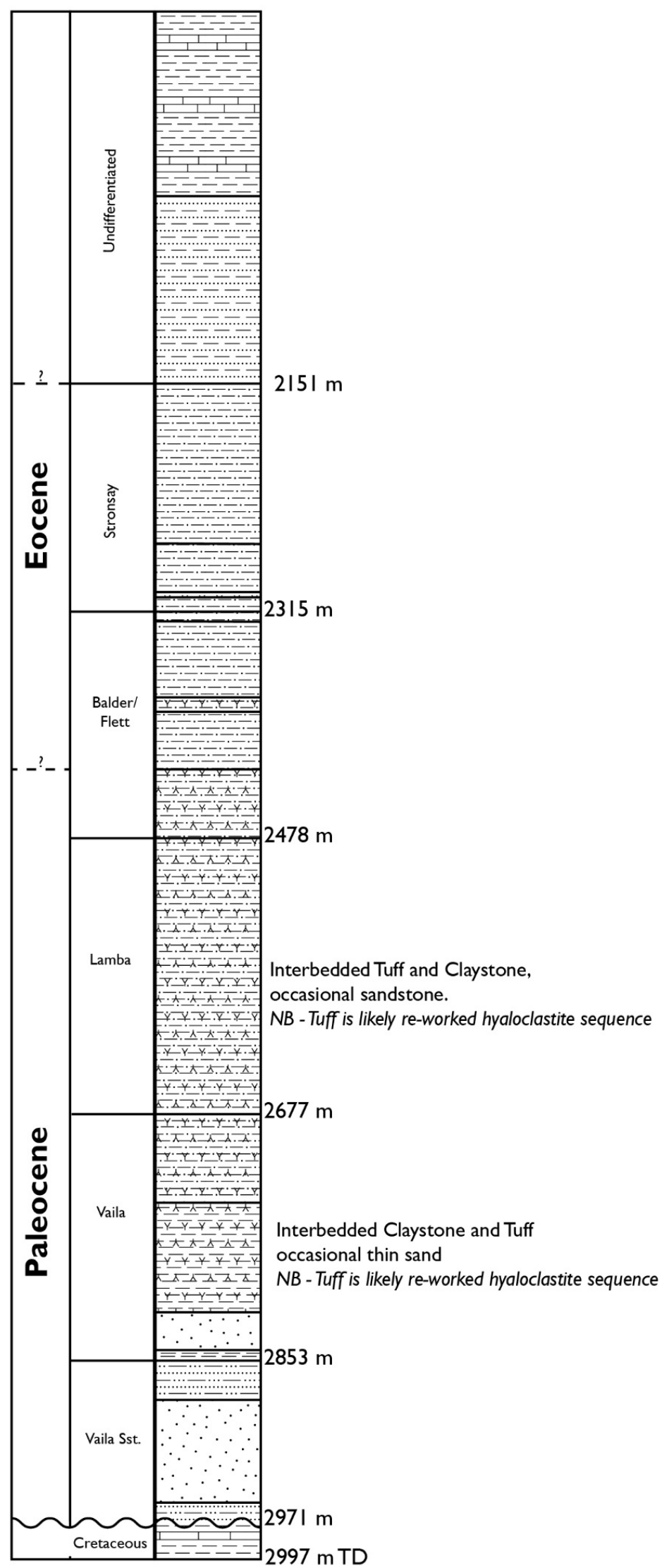

Figure 43 - Stratigraphic summary of I54/I-2 (Benbecula North) 


\section{Summary}

After the discovery of gas in Benbecula South (I54/I-I), I52/I-2 (Benbecula North) was drilled by Shell in 2006 to test the northern extent of the broader four-way dip closure that was penetrated by I54/I-I (Fig. 42). Upon drilling, although a similar thickness of Vaila Fm. sands were encountered, no hydrocarbons were detected, with the sands being found to be water wet (Fig. 43). This well was the final well drilled within the UK Rockall as of 2018.

\section{Structure}

Four-way structural closure

\section{Shows}

None

\section{Reservoir}

The well encountered the prognosed Vaila sandstone fm., found within I54/I-I, but also encountered a younger sandstone fan, which was not penetrated by I54/I-I. Pressure data from the Vaila sandstone sequences, was found to be on a different pressure gradient to the Vaila sequences penetrated by I54/I$\mathrm{I}$, suggesting that the sequence was not in pressure communication between the two well locations.

\section{Seal}

Not specifically stated in well reports.

\section{Potential Source Rocks}

No potential source rock sequences were penetrated by the well

\section{Comments}

As of 2018, Benbecula North (154/I-2) represents the last well drilled within the UK Rockall, and appeared to confirm that the greater closure that contains the Benbecula South Discovery was not filled. However, as noted above, pressure data appeared to show that I54/I-I and I54/I-2 where not in pressure communication, suggesting Benbecula North may have been compartmentalized from Benbecula South. Like Benbecula South, the trap forming Benbecula North seems to be implicitly related to underlying saucer-shaped sill intrusions causing forced-folds. The easterly wing of this intrusion appears to cut-up the Vaila sequence and may have acted to compartmentalize the Vaila reservoir sequence, and prevent its charging. 


\section{Findings of Well Audit}

\begin{tabular}{|c|c|c|c|}
\hline Well & $\begin{array}{l}\text { Year } \\
\text { Drilled }\end{array}$ & $\begin{array}{l}\text { Reason for failure of } \\
\text { Primary Target }\end{array}$ & Details \\
\hline $\begin{array}{l}163 / 06- \\
\text { IA }\end{array}$ & 1980 & $\begin{array}{l}\text { Drilling Issues I } \\
\text { Incorrect Prognosis }\end{array}$ & $\begin{array}{l}\text { Predicted sedimentary deltaic target was } \\
\text { volcanic hyaloclastite delta }\end{array}$ \\
\hline $\begin{array}{l}164 / 25- \\
1 Z\end{array}$ & 1988 & $\begin{array}{l}\text { Lack of Hydrocarbon } \\
\text { Charge }\end{array}$ & \\
\hline $164 / 25-2$ & 1990 & Incorrect Prognosis & $\begin{array}{l}\text { West Lewis basement ridge incorrectly } \\
\text { identified as pre-rift fault block }\end{array}$ \\
\hline $132 / 15-1$ & 1991 & Incorrect Prognosis & $\begin{array}{l}\text { Incorrect structural interpretation due to } \\
\text { poor data }\end{array}$ \\
\hline I54/03-I & 1991 & Incorrect Prognosis & $\begin{array}{l}\text { Volcanic delta misidentified as sedimentary } \\
\text { and West Lewis ridge as pre-rift fault block }\end{array}$ \\
\hline $164 / 07-1$ & 1997 & Incorrect Prognosis & $\begin{array}{l}\text { Timing and mechanism of trap formation } \\
\text { incorrectly predicted }\end{array}$ \\
\hline I53/05-I & 2000 & $\begin{array}{l}\text { Lack of Hydrocarbon } \\
\text { Charge/Trap? }\end{array}$ & \\
\hline $\begin{array}{l}164 / 28- \\
1 A\end{array}$ & 2000 & Lack of trap & Oil shows \\
\hline $132 / 06-1$ & 2001 & $\begin{array}{l}\text { Lack of Reservoir and } \\
\text { Hydrocarbon Charge }\end{array}$ & \\
\hline $164 / 27-1$ & 2002 & $\begin{array}{l}\text { Lack of Hydrocarbon } \\
\text { Charge }\end{array}$ & \\
\hline $154 / 0 \mid-2$ & 2006 & $\begin{array}{l}\text { Lack of Hydrocarbon } \\
\text { Charge }\end{array}$ & \\
\hline
\end{tabular}

\section{Incorrect Prognosis/Invalid Geological Targets}

The audit of the twelve wells drilled within the UK Rockall shows that five of the wells drilled targeted invalid geological targets that differed substantially from the pre-drill interpretation.

Well 163/6-la intended to target a prognosed clastic delta system beneath the lava sequences of North Rockall, although the well was abandoned due to drilling issues, in hindsight this sequence was likely a hyaloclastite volcanic sequence.

Well 164/25-2 targeted what was prognosed to be a pre-rift Jurassic-Carboniferous sequence, but the target was found to be Lewisian basement.

Well 132/I5-I was also intended to test prognosed pre-rift sequence, the primary target was also found to be Lewisian basement (the well is potentially located $1.4 \mathrm{~km}$ too far to SE and missed the pre-rift target).

Well 154/3-I targeted a prognosed clastic delta system beneath the Rockall lava sequences, but upon drilling this was found to be volcanic (hyaloclastite) in origin, overlying Lewisian basement. 
Well 164/7-I targeted large sub-basalt closure, interpreted to be composed of interbedded sands and mudstones, however on drilling the structure and reflectivity was found to be igneous in origin, with a series of $70+$ dolerite sills intruded into Cretaceous mudstone.

Within this report, wells were deliberately presented in a chronological order of drilling, to allow the reader to assess the changing exploration narrative of UK Rockall from 1980-2006 in response to increasing subsurface data and better seismic imaging. In this context, it important to emphasise that in none of the cases outlined where an invalid geological target was encountered, was the failure of the wells due to poor technical work on behalf of the operators. In each case, it is clear from well documents that substantial work was undertaken pre-drill by operators that was both rigorous and of a high technical standard. Rather, the numerous incorrect prognoses was a function of limited existing subsurface data, the embryonic state of understanding of volcanic sequences in a sedimentary basin setting and, importantly, the poor quality seismic data available at the time.

\section{Reservoir Risk}

Well 132/6-I prognosed primary reservoir sequences were not present, with the prognosed Frigg equivalent sand being claystone dominated. One observation from available pre-well prognosis of the wells drilled in the UK Rockall, is that there is a consistent over-prognosis/over-optimism on the amount of sand sequences predicted to be encountered in pre-drill assessments (e.g. I32/6-I, I54/I-I).

\section{Seal Risk}

No wells within the UK Rockall are perceived to have failed due to lack of seal. Laterally extensive sealing units exist within all major sequences from Eocene to Cretaceous. The multiple stacked sealing lithologies, existing through the stratigraphy of Rockall may have acted to segment and compartmentalize hydrocarbon migration and subsequent charge of reservoirs (e.g. potential stratigraphic isolation of Eocene - Paleocene fans within sealing claystone sequences in 132/I5-I). Any future well drilled within the basin must act to identify a viable charging route for the prognosed reservoir.

\section{Hydrocarbon Charge}

A lack of hydrocarbon charge is the second major reason why wells have failed within the UK Rockall with five wells having tested viable reservoir sequences, but with no hydrocarbons present. Although this could be attributed to the lack of a suitable and mature source to charge the reservoirs, the question needs to be also raised to if viable hydrocarbon routes existed into the sequences/targets. It is interesting to note, that in none of the well documents associated with the UK Rockall, is hydrocarbon migration mentioned in either pre-drill or post-drill analysis.

Well I64/25-Iz, situated to east of West Lewis Ridge penetrated several viable reservoir targets, however the lack of any shows, and also penetration straight from the Cretaceous into Permo-Triassic would point to there being a lack of a viable source to have charged I64/25-Iz. Even if Jurassic had been locally stripped 
during end Cretaceous-Paleocene uplift and exists deeper in the basin, the migration would still be up-dip away from the target.

Well 153/5-I drilled into one of the eastern basin margin Eocene fans, found no hydrocarbons despite good reservoir quality. The drilled prospect is underlain by extrusive? volcanic sequence, and pervasive sill network. Additionally, the fan is located considerably down dip from the eastern basin margin. Although imaging of the underlying basin stratigraphy and structure is challenging, it is likely that any hydrocarbon generated will have preferentially migrated up dip towards the eastern margin and outer Hebrides high. For the Eocene fan of 153/5-I to have become charged a viable cross-strata/cross-seal migration route would have had to exist to allow transmission of hydrocarbons through the Cretaceous, associated intrusive and extrusive volcanics.

Well I64/27-I intersected a thick $200 \mathrm{~m}$ Vaila Fm. equivalent sand package on the same sand fairway of the Vaila sequence penetrated by 164/28-Ia. Well I64/27-I is underlain by a substantial number of sills, which may have greatly increased migration tortuosity and baffled hydrocarbons away from the closure.

The potential issue with compartmentalization of Vaila sequences, leading to potential issues with hydrocarbon migration is illustrated by well 154/I-2 (Benbecula North), which although intersecting Vaila sequences equivalent to those of the I54/I-I discovery well, appeared non-connected due to difference in pressure regime between the Vaila sequence in each well.

Therefore, it is our conclusion that future wells drilled within the basin must act to identify a viable charging route for the prognosed reservoir prior to drilling.

\section{Discussion}

\section{Has the petroleum potential of Rockall been fully tested?}

With only 12 exploration wells, the UKCS Rockall Basin remains truly frontier and a high exploration risk. With only one discovery out of 12 wells, the basin has not been an attractive exploration target to many companies. We would argue however, that the above statistic is misleading, as this number reflects a high number of rank wildcats, before substantial subsurface knowledge of the UK Rockall could be established.

Out of the II dry holes drilled, five wells (163/6-Ia, I64/25-2, I32/I5-I, I53/3-I, I64/7-I) can be discounted as not representing proper tests of the UK Rockall petroleum system, as they were drilled on limited or incomplete geological data at the time, which led to substantially incorrect pre-drill interpretations and invalid exploration targets. This leads to a discovery vs. dry hole ratio of I:6.

Out of the remaining six wells, four of those wells have either been drilled on forced folds created by intrusions, or strongly associated with underlying intrusions, which may have led to issues with little or no hydrocarbon charge into the traps (I64/25-I, I z, I64/27-I, I64/28-IA and I54/I-2, I32/6-I).

We thus argue that the petroleum potential of Rockall has not been tested properly to date and, considerable new knowledge can be brought into the basin by applying geological learnings from other areas of the Atlantic Margin (e.g. identification of Colsay play and issues that extensive sill intrusions can cause from an exploration standpoint.).

Additionally, exploration in Rockall is potentially at odds with normal dip closure driven exploration and workflows within other UKCS and global basins, as in the UK Rockall, these closures have potentially not been subject to efficient hydrocarbon migration and charge (see Schofield et al. 20 I8). It is therefore an interesting proposition that the lack of discovery of hydrocarbons within the UK Rockall 
may be the result of protracted hydrocarbon migration routes, rather than lack of viable source rocks, which is often cited as the main inhibitor to exploration within the basin.

\section{Closing Remarks and Future Recommendations}

As of 2019, the UK Rockall still represents a challenging exploration environment, although there are several reasons for this (including lack of existing infrastructure), the two main fundamental challenges that remain a barrier to future exploration are I) Continued issues with seismic imaging caused by extrusive and intrusive volcanics and 2) The lack of deep well penetrations. These two aspects are explored in more detail below;

Seismic Imaging - Although the recent acquisition of new 2D data by the OGA and others (e.g. GeoPartners, WesternGeco) within the UK Rockall has led to an improvement in imaging and understanding of the general structure of the basin, challenges remain. The highly complex and rapidly changing lithological variability within the basin (in particular within the extrusive and intrusive volcanic sequences) means that subsurface imaging remains challenging with $2 \mathrm{D}$ surveys alone. Realistically, a significant uplift in imaging and thus subsurface understanding arguably can only be achieved by the acquisition of modern 3D data, utilizing broadband acquisition and modern processing techniques. This has been successfully demonstrated in the FSB in zones of substantial extrusive and intrusive components (e.g. Cambo and Rosebank areas).

Well Penetrations - The lack of deep well penetrations within the basin is problematic, as the full stratigraphy of the UK Rockall is still not fully understood, let alone properly tested from a hydrocarbon prospectivity viewpoint. The stratigraphic test well 163/6-la, drilled in 1980, was $49 \%$ funded by 19 companies, and $51 \%$ by the then Department of Energy, and the nationalised BNOC and British Gas Corporation. In hindsight, due to the well location, its findings where arguably minimal from a hydrocarbon perspective, however, it does raise the concept of if a new stratigraphic test/hydrocarbon finder well involving a large industry consortium, with government backing, is needed to re-kick-start exploration some 38 years after 163/6-la was drilled. A finder well designed to fully test the deepstratigraphy and confirm the presence (or not) of Jurassic source rocks within the eastern deep-water margin of Rockall is potentially needed to act to de-risk the area and provide the necessary subsurface data and incentive to further explore the UK Rockall. 


\section{Acknowledgments}

We would like to thank OGA for providing funding and continued enthusiasm and support of project. GeoPartners and TGS are thanked for donation of Rockall Regional 20I3-20I4 Survey. Zyg Sarnowski (GeoPartners) is thanked for continued support and discussions on project. Frogtech are thanked for providing access to their UK Rockall SEEBASE study.

Seismic interpretation was carried out using academic licenses of Schlumberger's Petrel and IHS Kingdom Software. Esri are also thanked for provision of their ArcGIS software.

Dr Clayton Grove (Siccar Point Energy) and Dr. Simon Holford (Australian School of Petroleum) are thanked for discussions.

\section{References}

Archer, S. G., Bergman, S. C., lliffe, J., Murphy, C. M., and Thornton, M. (2005). Palaeogene igneous rocks reveal new insights into the geodynamic evolution and petroleum potential of the Rockall Trough, NE Atlantic Margin. Basin Research, I7(I), I7I-20I.

Cole, J. E., \& Peachey, J. (1999, January). Evidence for pre-Cretaceous rifting in the Rockall Trough: an analysis using quantitative plate tectonic modelling. In Geological Society, London, Petroleum Geology Conference series (Vol. 5, pp. 359-370). Geological Society of London.

Doré, A. G., E. R. Lundin, C. Fichler, and O. Olesen. "Patterns of basement structure and reactivation along the NE Atlantic margin." Journal of the Geological Society I54, no. I (1997): 85-92.

Ebdon, C.C., Granger, P.J., Johnson, H.D., and Evans A.M., 1995. Early Tertiary evolution and stratigraphy of the Faeroe-Shetland Basin: Implications for hydrocarbon prospectivity. In: Scrutton R.A., et al. (eds) Sedimentation and palaeoceanography of the North Atlantic region, Geological Society of London, Special Publication 90: 51-69

Ellis, D., \& Stoker, M. S. (20I4). The Faroe-Shetland Basin: A regional perspective from the Paleocene to the present day and its relationship to the opening of the North Atlantic Ocean. Geological Society, London, Special Publications, 397(I), II-3I.

Emeleus, C. H., \& Bell, B. R. (2005). The Palaeogene volcanic districts of Scotland (Vol. 3). British Geological Survey.

England, R.W., Butler, R.W.H. \& Hutton, D.H.W. 1993. The role of Paleocene magmatism in the Tertiary evolution of basins on the NW seaboard. In: Parker, J.R. (ed.) Petroleum Geology of Northwest Europe: Proceedings of the 4th Conference. Geological Society, London,

97-105, https://doi.org/ I0.1 I44/0040097.

Fyfe, J.A., Long, D. \& Evans, D. 1993. The Geology of the Malin-Hebrides Sea Area. United Kingdom Offshore Regional Report, 4. British GeologicalSurvey, HMSO, London.

Hansen, D.M. and Cartwright, J., 2006. The three-dimensional geometry and growth of forced folds above saucer-shaped igneous sills. Journal of Structural Geology, 28(8), Pp. I520-I535

Hitchen, K. and Stoker, M.S., 1993. Mesozoic rocks from the Hebrides Shelf and implications for hydrocarbon prospectivity in the northern Rockall Trough. Marine and Petroleum Geology, 10(3), pp.246-254.

Hitchen, K., Johnson, H. \& Gatliff, R. W. (eds) 2013, Geology of the Rockall Basin and Adjacent Areas. British Geological Survey, London, Research Report RR/I2/03, 96- I36

Holford, S. P., Green, P. F., Hillis, R. R., Underhill, J. R., Stoker, M. S., and Duddy, I. R. (2010). Multiple post-Caledonian exhumation episodes across NW Scotland revealed by apatite fission-track analysis. Journal of the Geological Society, 167(4), 675-694. 
Isaksen, G.H., Wall, G.R., Thomsen, M.A., Tapscott, C.R., Wilkinson, D.R. and McClachan, K., 200 I. Application of petroleum seep technology in mitigating the risk of source-rock adequacy and yieldtiming in a frontier basin: the Rockall Trough, UK. Earth System Processes.

Jones, D. W., \& Underhill, J. R. (20II). Structural and stratigraphic evolution of the Connemara discovery, Northern Porcupine Basin: significance for basin development and petroleum prospectivity along the Irish Atlantic Margin. Petroleum Geoscience, I7(4), 365-384.

Knott, S.D., Burchell, M.T., Jolley, E.J. and Fraser, A.J., 1993, January. Mesozoic to Cenozoic plate reconstructions of the North Atlantic and hydrocarbon plays of the Atlantic margins. In Geological Society, London, Petroleum Geology Conference series (Vol. 4, No. I, Pp. 953-974). Geological Society of London.

Lundin, E.R. \& Dore', A.G. 20I I. Hyperextension, serpentinization, and weakening: A new paradigm for rifted margin compressional deformation. Geology, 39, 347-350.

Millett, JM., Hole, MJ., Jolley, DW., Schofield, N. \& Campbell, E. (20I6). 'Frontier exploration and the North Atlantic Igneous Province: new insights from a $2.6 \mathrm{~km}$ offshore volcanic sequence in the NE Faroe-Shetland Basin'. Journal of the Geological Society, vol I73, no. 2, pp. 320-336.

Mclnroy, D. and Hitchen, K., 2008. Geological evolution and hydrocarbon potential of the Hatton Basin (UK sector), north-east Atlantic Ocean. In Proceedings of Central Atlantic Conjugate Margins Conference, Halifax, 2008 (pp. I32-I43).

Morton, N. (1992). Dynamic stratigraphy of the Triassic and Jurassic of the Hebrides Basin, NW Scotland. Geological Society, London, Special Publications, 62(1), 97-I 10.

Musgrove, F. W., \& Mitchener, B. (1996). Analysis of the pre-Tertiary rifting history of the Rockall Trough. Petroleum Geoscience, 2(4), 353-360.

Nadin, P. A., Houchen, M. A., \& Kusznir, N. J. (1999, January). Evidence for pre-Cretaceous rifting in the Rockall Trough: an analysis using quantitative 2D structural/stratigraphic modelling. In Geological Society, London, Petroleum Geology Conference series (Vol. 5, pp. 37I-378). Geological Society of London.

Passey, S.R., and Jolley, D.W., 2009, A revised lithostratigraphic nomenclature for the Palaeogene Faroe Islands Basalt Group, NE Atlantic Ocean: Earth and Environmental Science Transactions of the Royal Society of Edinburgh, v. 99, p. 127-I58.

Rateau, R., Schofield, N., and Smith, M. (2013). The potential role of igneous intrusions on hydrocarbon migration, West of Shetland. Petroleum Geoscience, 19(3), 259-272.

Scotchman, I.C., Dore', A.G. \& Spencer, A.M. 2016. Petroleum systems and results of exploration on the Atlantic margins of the UK, Faroes \& Ireland: what have we learnt? In: Bowman, M. \& Levell, B. (eds) Petroleum Geology of NW Europe: 50 Years of Learning - Proceedings of the 8th Petroleum Geology Conference. Geological Society, London, first published online October 27, 2016, https://doi.org/10.1144/PGC8.14

Schofield, N., and Jolley, D.W (2013) - Development of Intra-Basaltic Lava Field Drainage Systems within the Faroe-Shetland Basin, Petroleum Geoscience, Vol. 19, pp. 259-272

Schofield, N., Holford, S., Millett, J., Brown, D., Jolley, D., R. Passey, S., Muirhead, D., Grove, C., Magee, C., Murray, J., Hole, M., A.-L. Jackson, C. and Stevenson, C. (20I5), Regional magma plumbing and emplacement mechanisms of the Faroe-Shetland Sill Complex: implications for magma transport and petroleum systems within sedimentary basins. Basin Res. doi: I0.1 I I I/bre.12164

Schofield, N., Jolley, D., Holford, S., Archer, S., Watson, D., Hartley, A., Howell, J., Muirhead, D., Underhill, J. and Green, P., 2018, February. Challenges of future exploration within the UK Rockall Basin. In Geological Society, London, Petroleum Geology Conference series (Vol. 8, Pp. PGC8-37). Geological Society of London.

Shannon, P., \& Naylor, D. (2010). Petroleum Geology of Ireland. Dunedin Academic Press. 
Srivastava, S.P. and Verhoef, J., 1992. Evolution of Mesozoic sedimentary basins around the North Central Atlantic: a preliminary plate kinematic solution. Geological Society, London, Special Publications, 62(I), Pp.397-420.

Stein, A.M. and Blundell, D.J., 1990. Geological inheritance and crustal dynamics of the northwest Scottish Continental Shelf, Tectonophysics, I73, 455-467.

Štolfová, K., \& Shannon, P. M. (2009). Permo-Triassic development from Ireland to Norway: basin architecture and regional controls. Geological Journal, 44(6), 652-676

Trewin, N.H. (ed.) 2002. The Geology of Scotland. Geological Society, London.

Waters, C N, Gillespie, M R, Smith, K, Auton, C A, Floyd, J D, Leslie, A G, Millward, D, Mitchell, W I, McMillan, A A,Stone, P, Barron, A J M, Dean, M T, Hopson, P M, Krabbendam, M, Browne, M A E, Stephenson, D, Akhurst, M C, andBarnes, R P. 2007. Stratigraphical Chart of the United Kingdom: Northern Britain. British Geological Survey, I poster. 